\title{
Policy Interventions and Smallholder Market Linkage: Case Study from Nicaragua
}

\author{
Dissertation \\ to obtain the Ph.D. degree \\ in the International Ph. D. Program for Agricultural Sciences in Göttingen \\ (IPAG) \\ at the Faculty of Agricultural Sciences, \\ Georg-August-University Göttingen, Germany \\ presented by \\ Ayako Ebata \\ born in Japan
}

Göttingen, May 2015 

D7

1. Name of supervisor: Prof. Dr. Stephan von Cramon-Taubadel

2. Name of co-supervisors: Prof. Dr. Bernhard Brümmer, Jun.-Prof. Dr. Meike Wollni

Date of dissertation: 23. July, 2015 



\section{Summary}

Smallholder market participation has been discussed as a catalyst against poverty. To date, a number of empirical studies have addressed the effect and implication of smallholder inclusion in commercial markets. Generally, the literature agrees that commercial marketing increases household welfare and points out several key endowments that are crucial for smallholder participation in market transactions. This dissertation extends such findings by directly addressing policy tools to enable market linkage of small farmers in rural areas. More specifically, it looks at road infrastructure improvement and NGO-based market linkage assistance. While the role of transportation infrastructure is considered crucial for market participation by small farmers, the quantification of benefits from improving rural roads had not been done in a satisfactory manner. In addition, most studies treat NGO-based intervention as one component, failing to capture distinct roles played by different activities. Therefore, this dissertation fills the gap in the literature by studying bean farmers in rural Nicaragua. The research shows that a reduction of time traveled to commercial markets by 25\% would increase household income from bean sales by between 3 and $12 \%$ of the current income. Regarding the effect of different NGO activities, we find that entrepreneurial practices-related activities show positive correlation with sales volume directed to non-local markets, confirming the effectiveness of the intervention. We also show that different groups of farmers benefit from interventions differently. Those who did not participate in commercial marketing previously benefited more than those who were already part of the supply chain before the project intervention. 


\section{Acknowledgements}

In 2010, when I completed my Master's degree, I would have never imagined obtaining a doctorate. I would like to thank those who inspired and assisted me to get through the process of bringing my doctoral project to a successful end.

First of all, I would like to thank Prof. Stephan von Cramon-Taubadel and the GlobalFood program for giving me this wonderful opportunity. Thank you. In addition, I am grateful for the financial support by the German Research Foundation and the German Academic Exchange Service.

My empirical analysis would not have been possible without the assistance from the International Center for Tropical Agriculture in Colombia and the Catholic Relief Services in Nicaragua. Special thanks goes to Carolina Gonzalez, Veronica Gottret, Juan Alberto Molino Centeno, Erika de Fatima Herrera Mora, Fredred Valdiva, and Thomas Kirkland.

I am also thankful for the professional interactions I had with Dr. Manuel Hernandez from IFPRI and Prof. Silke Hüttel from University of Rostock. Also, my work was done in collaboration with two Master's students at the University of Göttingen: thank you, Isabel Pleisnitzer and Pamela Alejandra Velasco Pacheco.

I would also like to acknowledge previous colleagues and supervisors at the University of Nebraska-Lincoln and CIAT for encouraging me to continue with a PhD. Thank you, Dr. Lilyan Fulginiti, Dr. Richard Perrin, Dr. Rod Lefroy, Dr. Ruben Echeverria, and Sok Sophearith.

Words cannot express how grateful I am for all the friends, both near and far away, who made my experiences in Germany memorable and provided me with unconditional support. I would like to take this opportunity to thank all my Japanese, German and international families around the globe. Thank you for all the tea-, wine- and ginger ale-drinking, badminton, yoga, walking and jogging, wonderful food, and countless hours of chatting with good laughter.

I am most grateful for my family who has understood and supported me with the path I have chosen. Thank you for showing your love and watching me grow as a person.

Last, but not least, I would like to thank all these farmers I had the chance to meet and talk to throughout my professional experiences. Thank you for taking your time to talk about your life and welcoming us in your humble homes. The inspiration you have given me has always been the driving force to go another step further. Now that I am completing my studies with your help, I sincerely hope to pay it forward some day.

ii | P a g e 


\section{List of tables}

Table 2.1. Farm size and number of bean producers in Nicaragua: 2011 ...................................... 7

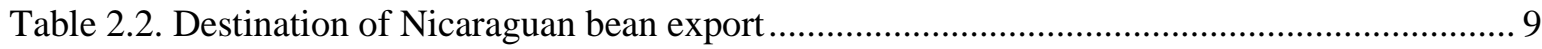

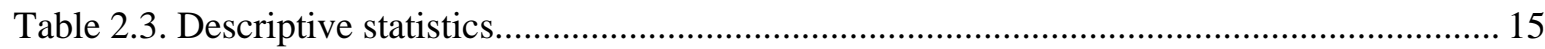

Table 2.4. Regression results (t-values in brackets) …............................................................ 17

Table 3.1. Number of producers who participated in intervention activities: 2007-2012 ................ 23

Table 3.2. Number of bean producers who sold in different markets: 2006-2012 .......................... 25

Table 3.3. Quantity of bean sales (qq) to linked and local markets: 2006-2012 ........................... 25

Table 3.4. Comparison between market linkage program participants and non-participants ........... 27

Table 3.5. Regression results: $\mathrm{Y}=$ Quantity (qq) sold in linked markets (t-value in brackets) ........ 30

Table 3.6. Regression results: $\mathrm{Y}=$ Fraction (\%) of quantity sold in linked markets ( $\mathrm{t}$-value in

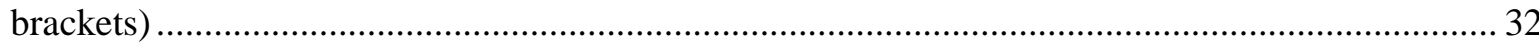

Table 3.7. Regression results: $\mathrm{Y}=$ total bean sales income (USD) ( $\mathrm{t}$-value in brackets).................. 33

Table 4.1. Comparison between market linkage program participants and non-participants ........... 38

Table 4.2. Regression results: extensive margin (t-values in brackets) ...................................... 42

Table 4.3. Regression results: intensive margin (t-values in brackets) ............................................ 44

Table 6.1. Agricultural area (Ha) reported in the national statistics: 2011 census........................... 52

Table 6.2. Number and percentage of the project participants who belong to a cooperative............ 53

Table 6.3. Number of the project participants by department: 2006-2012 ...................................... 55

Table 6.4. Number of project participants by commodity: 2006-2012 ......................................... 55

Table 6.5. Number of project participants who sold more than one crop: 2006-2012 _.................... 56

Table 6.6. Number of the project participants by the number of crops they produced ..................... 56

Table 6.7. Producers divided by size categories (Ha): 2006-2012 _............................................. 57

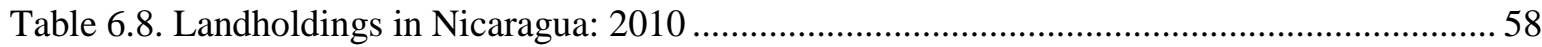

Table 6.9. Number of the project participants by capacity building activity: 2006-2012 ................ 58

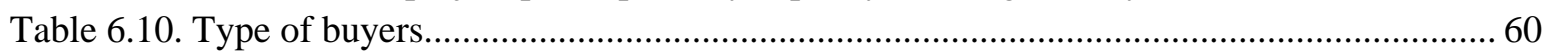

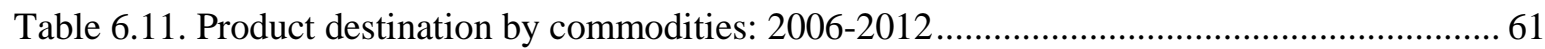

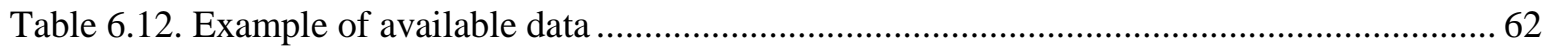




\section{List of figures}

Figure 2.1. Production, domestic supply and trade of beans in Nicaragua: 2000-2011 .................... 8

Figure 2.2. Share of value exported from various ports in Central America ................................... 12

Figure 2.3. Distribution of farm-gate prices........................................................................... 14

Figure 3.1. Possible impact pathway of the market linkage program ............................................ 24

Figure 6.1. Map of Nicaragua with departments........................................................................ 50

Figure 6.2. Project funding distribution: September 2007-October 2012 ..................................... 51

Figure 6.3. Selection process of project participants.................................................................... 54 


\section{Definitions of Key Terminologies}

Supply Chains:

"the system in which a product moves from (i) the farmer and first-stage processor, who sorts, grades, packs, and does the initial processing ("upstream" in the chain), to (ii) the distributor, including assemblers and wholesalers, to the "downstream" segments, (iii) the second-stage processor or "food manufacturer" (unless the product is a fresh product), to (iv) the retailer (such as supermarket or restaurant), and thence to (v) the consumer” (Reardon et al., 2002, p. 1)

Value Chains:

the chain of activities that bring value to commodities (Feller et al., 2006)

Smallholders:

"producers of agricultural and forest products or services who manage small-scale landholdings, whose size varies according to the local context” (Donovan \& Stoian, 2012, p. 14)

Traditional markets:

"wet markets" (Schipmann \& Qaim, 2011, p. 346)

markets where product exchange is "loose” (Assefa \& Minten, 2015, p. 8)

other terms used: local markets, wholesales markets, non-linked markets

Linked markets:

all market types except local wholesale markets as linked markets (see Chapter 3)

other terms used: non-local markets, non-traditional markets, dynamic markets 


\section{Table of Contents}

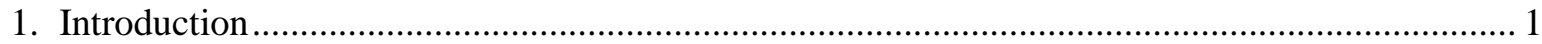

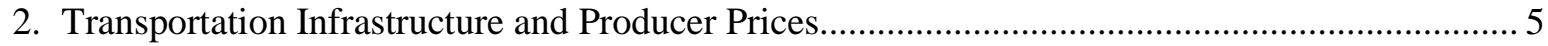

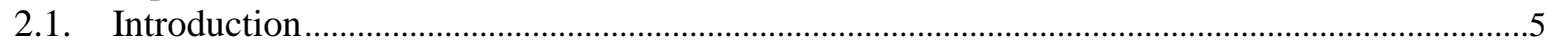

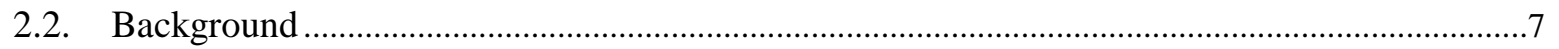

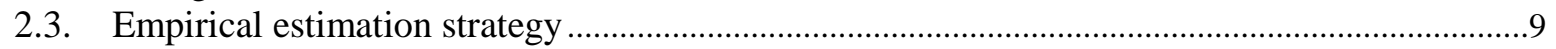

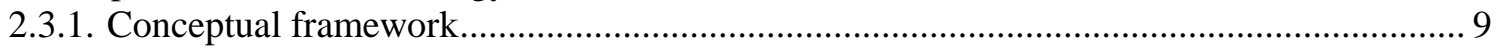

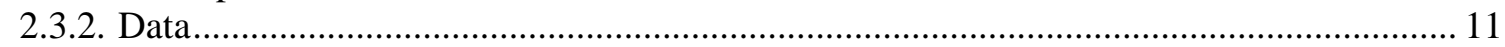

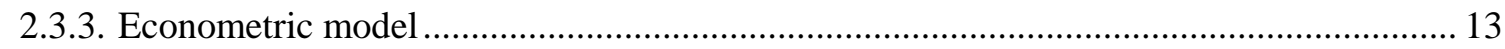

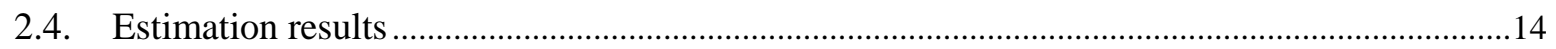

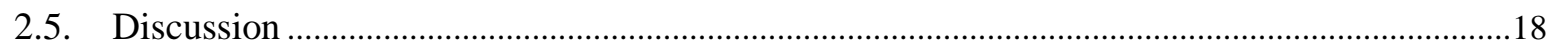

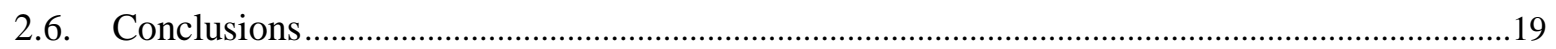

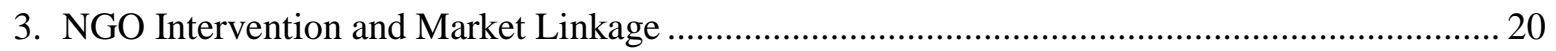

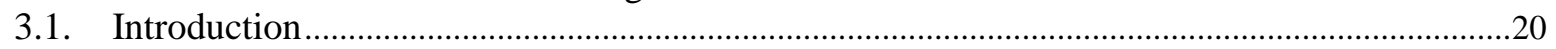

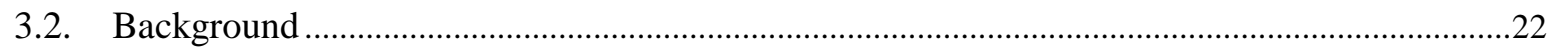

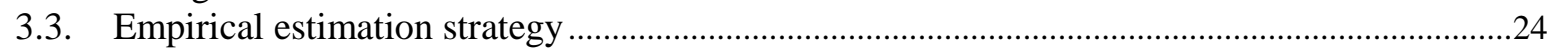

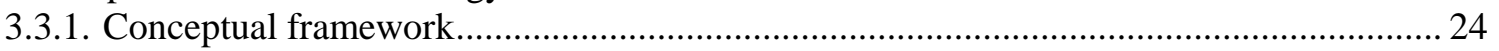

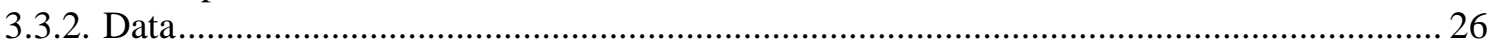

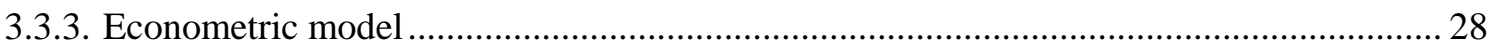

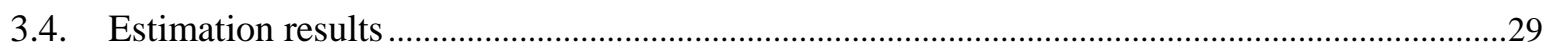

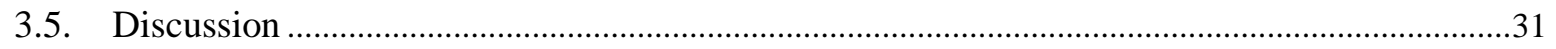

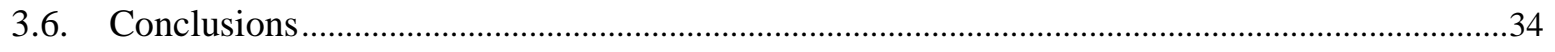

4. Intensive and Extensive Margins of NGO Interventions ..................................................... 35

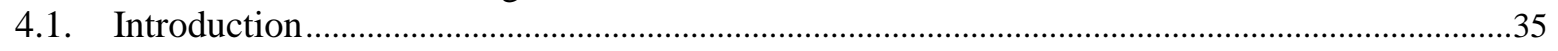

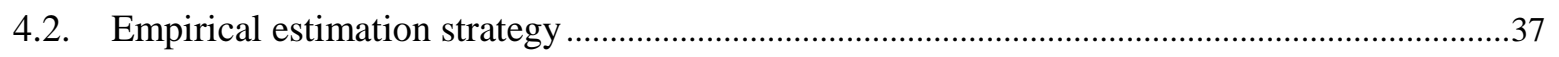

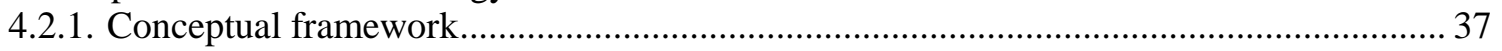

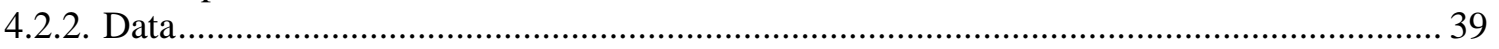

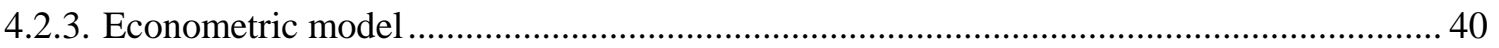

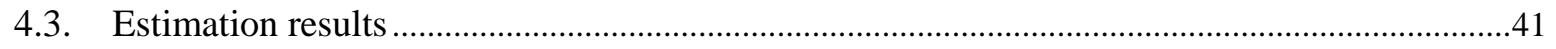

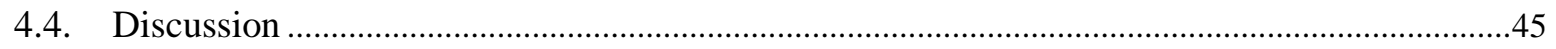

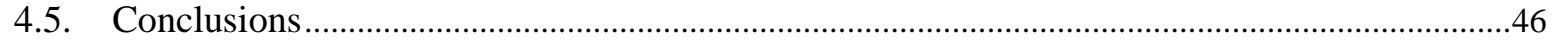

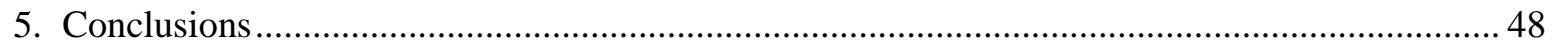

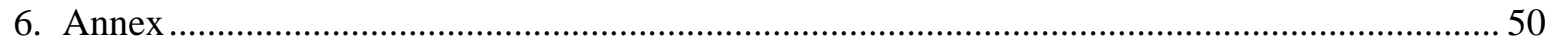

6.1. Description of the project ACORDAR: 2007-2012 …..........................................................

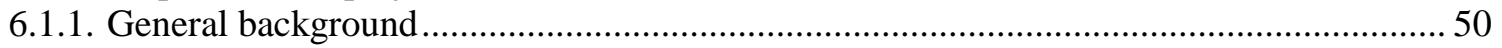

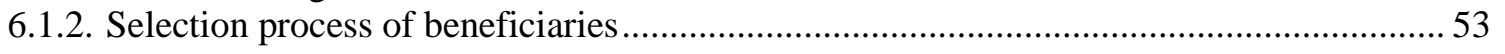

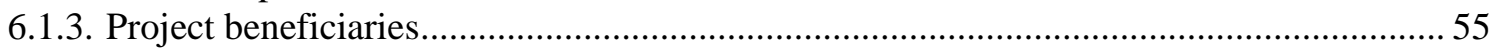

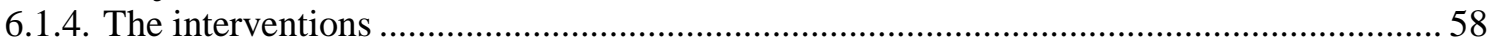

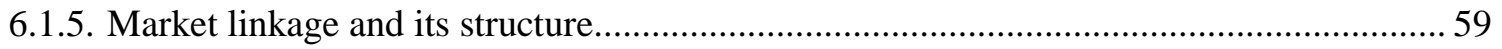

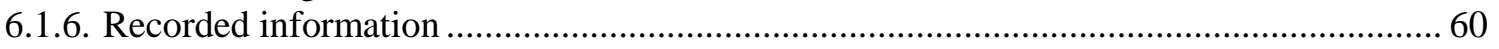

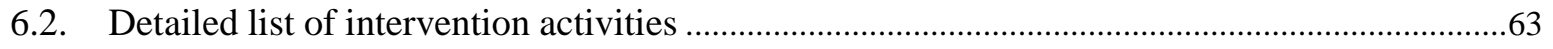

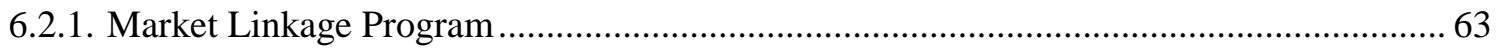

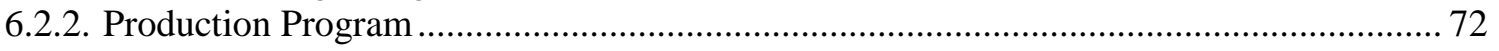

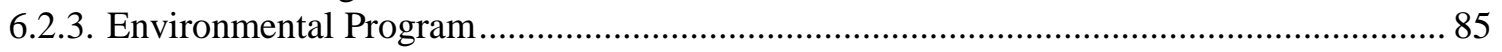

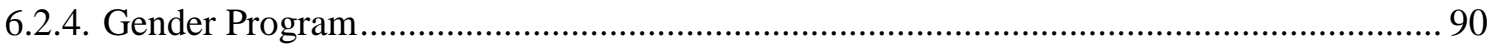

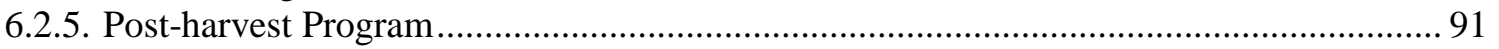

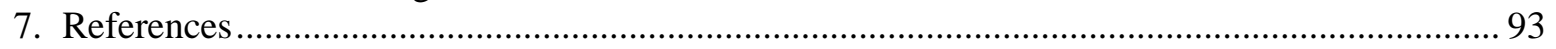

vi |P a g e 


\section{Introduction}

Commodity trade as a result of comparative advantage has long been considered as an effective tool to achieve welfare gains. Early on, David Ricardo claimed that specialization in production and exchange of goods allow individual production units to reach welfare levels higher than in the autarkic state (Ricardo, 1891). Since Ricardo, researches have shown that trade brings growth and economic development (see for example Frankel \& Romer, 1999; Frankel et al., 1996; Romer, 1994).

In addition to gains from trade at the economy level, agricultural economists have drawn a link between (agricultural) commercialization and rural poverty reduction. For instance, Timmer (1997) explains how economic growth is accompanied with agricultural transformation (e.g. productivity increase, technology improvement and adoption), followed by commercialization (i.e. production specialization at the farm level), and finally society-wide agricultural diversification. This process reduces dependency on agriculture as a source of income and employment at the economy level. As a result, it allows reallocation of production resources away from agriculture and rural areas, driving development in non-farm sectors (Timmer, 1988). As Bromley \& Chavas (1989) and Barrett et al. (2010) argue, economic development cannot be achieved without first transforming the agricultural sector. In this notion, policies neglecting agricultural development has been criticized as a culprit for stagnant economic growth (Binswanger, 1998).

While fundamental to developing the agricultural sector are access to productive assets and wellfunctioning markets for both public and private goods (Barrett, 2008), many developing countries often lack these necessary mechanisms. Lack of assets prevents smallholders from making investment (Barrett, 2008; Naschold, 2012), which leads to slow total factor productivity growth. Non-existing input and output markets increase transaction costs for smallholders to participate in commercial markets (de Janvry et al., 1991; Fafchamps, 1993; Key et al., 2000; Alene et al., 2008). As a result, many poor farmers miss out on continuous market-based exchange that provides them with necessary information, which further decreases the incentive to improve production technology (Barrett et al., 2010). Without institutional support, poor farmers in developing countries have no choice but to opt out of commercialization and remain in a poverty trap characterized with low productivity, little crop specialization and little to non-existing market participation (Barrett \& Swallow, 2006; Naschold, 2012).

In essence, commercialization is impeded due to non-negligible transactions costs. This is why a large body of literature addresses their role in the context of smallholder commercialization in developing countries. Key et al. (2000) categorize transaction costs in partial transactions costs (PTCs) and fixed transaction costs (FTCs). PTCs may be generated due to physical distance and remoteness (Jacoby \& Minten, 2009; Jacoby, 2000), transportation infrastructure (Fafchamps \& Hill, 2005), lack of access to information (Goetz, 1992; Torero, 2011), and dysfunctional markets (de 
Janvry et al., 1991; Fafchamps, 1993). Generally speaking, PTCs raise per unit cost of products exchanged, creating a "price band within which some households find it unprofitable to either sell or buy” (Key et al., 2000, p. 245). FTCs arise in the form of search costs for reliable and profitable markets, negotiation and bargaining under information asymmetry, and screening to control product quality (Key et al., 2000). Perceiving the risks and uncertainties associated with market participation, poor farmers strategically choose to diversify crop production and thereby forgo opportunities for commercialization and welfare gains (Barrett, 2008; Omamo, 1998a).

In practice, encouraging smallholder commercialization is a complex task (Boselie et al., 2003). Generally, the empirical literature agrees to reduce transaction costs by improving physical infrastructure to both inputs and outputs markets as well as reducing risks and uncertainties associated with marketing (Torero, 2011). More specifically, research has recommended that policy makers facilitate communication and interactions between buyers and producers (vertical coordination), encourage collective actions in a form of farmer groups and cooperatives (horizontal coordination), and improve access to production technology and other infrastructure that enables processing for value-added products (Boselie et al., 2003; Hellin et al., 2009; Minten et al., 2009; Torero, 2011; Whitfield, 2012). In addition, the policy environment should favor such commercial activities both at the national and international level (Barrett, 2008; Minten et al., 2009).

In this context, the emerging global supply chains have attracted much attention as a solution to mitigate such aforementioned problems. Driven largely by decreased trade control by national states and change in consumer preferences, the share of high-value goods traded has increased and large global retailers have increasingly integrated smallholder farmers into their global supply chains (Chopra et al., 2002; Codron et al., 2006; Dolan \& Humphrey, 2000; Maertens \& Swinnen, 2007; Pingali, 2007; Reardon et al., 2002). A number of studies identify positive effects on those included in the global procurement system (see for instance Minten et al., 2009; Nagaraj et al., 2008; Rao \& Qaim, 2011).

However, even in the wake of globally integrated markets, aforementioned obstacles that small farmers face are visible. Coexisting with positive effects of the modern procurement system are empirical evidences that resource poor farmers lack necessary mechanisms to meet quality and quantity requirements imposed by retail companies (Farina \& Reardon, 2000; Swinnen, 2007). As a result, many smallholders are unable to take advantage of the opportunities in such integrated markets in the long-run (Hazell et al., 2010; Markelova et al., 2009).

The exact mechanisms that enable smallholder market linkage is case-specific (Torero, 2011). Thus, the universally agreed upon recommendation to improve infrastructure needs to be translated to concrete implementation tools in individual cases. Moreover, effective policies are likely to be dependent on the type of producers. Torero (2011) divides smallholders in three categories ${ }^{1}$ : those who 1 . are market-oriented and competitive, 2. commercialize regionally and/or nationally, and 3.

\footnotetext{
${ }^{1}$ Similar classification is mentioned by Barrett (2008).
}

$2 \mid \mathrm{P}$ a g e 
rarely participate in market transactions and live in semi-subsistence system. Increasing market participation by the first group does not require the same set of policy interventions as in the case for the third group.

While the complexity of long-term smallholder commercialization has been pointed out, the empirical literature to date fails to provide satisfactory evidences as to what extent what intervention tools are effective in building inclusive value chains. Often, problems are nested in the non-random nature of interventions (e.g. road development, donor-funded projects) (Barrett, 2008; Jacoby \& Minten, 2009). As a result, eliciting causal relationship between certain interventions and commercialization is challenging. As commercialization-oriented interventions are relatively new (Jaffee et al., 2011), research to date lacks thorough discussions regarding their effectiveness (Barrett, 2008; Humphrey \& Navas-Alemán, 2010; Mithofer, 2011; Stoian et al., 2012).

To fill the aforementioned gap in the literature, this dissertation studies two mechanisms that are seen effective in reducing transaction costs and thus facilitating smallholder participation in commercial markets. Building up on three essays, this dissertation addresses the following research questions:

RQ1: How much do smallholder farmers benefit from rural road development?

RQ2: Do NGO-based intervention activities link smallholders to commercial markets?

RQ3: Do NGO-based intervention activities affect entrant and already-existing farmers differently?

All case studies are conducted on staple bean producers in Nicaragua, the second poorest country in Latin America (IFAD, n.d.). Staple commodities are generally perceived less profitable than cash crops and fresh produce. This is mainly because there is little product differentiation that generates premium prices (Berdegué, 2002; Hellin et al., 2009). Moreover, prices of staple commodities are deliberately kept low through government interventions to feed the population and avoid political instability (Timmer, 2010; von Braun et al., 2008). Lacking incentive to update technology, yield of many staple grains remains low in the developing world. While commercial exchange of staple commodities implies reallocation of production resources to more profitable crops, many poor agricultural producers maintain food crop production in order to avoid being food insecure (Omamo, 1998b). Therefore, studying the case of staple beans provides insights as to what policy tools can be used to encourage commercialization of staple commodities, and therefore further extending to cash crops in the future.

Data set is obtained from a non-governmental organization (NGO), the Catholic Relief Services (CRS). CRS conducted a development project between 2007 and 2012 and recorded information on sales activities of various commodities. There are a total of 5,045 bean producers. We exploit the full unbalanced panel data set.

The first essay quantifies the benefit of rural transportation infrastructure development by scrutinizing farm-gate prices of bean producers. Improving roads in rural areas is considered as one of the key intervention tools to encourage smallholder market participation (Jacoby \& Minten, 2009; 
Rapsomanikis et al., 2006; Renkow et al., 2004). In addition, remote areas demonstrate less market integration compared with well-linked regions (Barrett, 1996; Baulch, 1997; Fackler \& Goodwin, 2001; Ravallion, 1986). This reduces the influence of macro-level policy interventions (Barrett, 2008; Dethier \& Effenberger, 2012). However, quantification of benefit has been challenging and neglected due to the non-random nature of rural road development (Jacoby \& Minten, 2009). We propose a novel approach to tackle this problem by analyzing producer prices. Building up on a hedonic price model (Rosen, 1974), we confirm that larger distance to commercial markets depresses producer prices in rural areas. Our results suggest that a $25 \%$ reduction in travel time to commercial markets would increase bean sales revenue by between at least 3\% and $12 \%$ annually. Since road development will benefit other producers, crops and industries, we expect the return to be larger than estimated.

The second essay scrutinizes capacity building activities undertaken by an NGO in order to understand the effectiveness of project interventions. Donor-funded projects show increasing interest in supporting smallholder participation in commercial markets (Barrett, 2008; Humphrey \& Navas-Alemán, 2010; Shepherd, 2007). While NGO-based activities are generally found useful (e.g. Carletto et al., 2011; Kersting \& Wollni, 2012), there is a lack of empirical evidence as to whether and how much desired outcomes are attributed to NGO interventions (Jaffee et al., 2011; Mithofer, 2011). Using a difference-in-differences approach, we identify what intervention activities have positive effects on linking smallholders to markets. We find entrepreneurial training increases bean market linkage by between 0.2 and 0.5 percentage points. Moreover, the higher the percentage of outputs sold in dynamic markets, the larger the sales income.

The third essay extends the analysis done in the third chapter by identifying who benefit most. The empirical literature emphasizes heterogeneity among agricultural producers in regard to commercialization. Generally speaking, those who are integrated in commercial markets are physically, personally, and/or institutionally more endowed than those who are excluded (e.g. Barrett et al., 2012; Berdegué et al., 2005; Gulati et al., 2007; Swinnen, 2007). To test whether NGO activities assist particularly those that had not participated in dynamic markets before being intervened, we employ the concept of intensive and extensive margins from the trade literature. We divide bean producers into two groups: those who had participated in commercial activities prior to NGO interventions and those who had not. The evidences suggest that trainings on commercialization have positive influences on previously excluded farmers but show no effect on the rest at both margins. Based on the findings, we recommend future projects to focus solely on training those who had lacked access to dynamic markets prior to interventions as well as conduct thorough contextual analysis prior to interventions.

The rest of this dissertation is organized as follows. Chapter 2 presents the first essay on quantification of benefits from road development. Chapter 3 investigates the effectiveness of an NGO project in linking farmers to commercial markets (Essay Two). Chapter 4 gives insights as to who benefit from the interventions (Essay Three). Finally, Chapter 5 summarizes and concludes. All supplementary materials are found in Chapter 6.

$4 \mid \mathrm{P}$ a g e 


\section{Transportation Infrastructure and Producer Prices ${ }^{2}$}

\subsection{Introduction}

In today's changing agri-food system, smallholder participation in commercial markets has attracted attention as a potential catalyst for alleviation of poverty. Farmers who are included in the global procurement system are found to benefit from premium product prices (Gulati et al., 2007), reduced transactions costs in product marketing (Nagaraj et al., 2008; Vieira, 2008), and access to necessary assets (Minten et al., 2009; Nagaraj et al., 2008; Swinnen, 2007). As a result, participating farmers are able to improve productivity, household income and/or asset holdings (Minten et al., 2009; Miyata et al., 2009; Reardon et al., 2009). However, participation in global supply chains requires good access to roads and other transportation infrastructure, production assets (e.g. irrigation system), and thorough knowledge of farming techniques among others (Barrett et al., 2012; Donovan \& Poole, 2008; Hernandez et al., 2012; Michelson, 2013; Murray, 1991; Rao \& Qaim, 2011). For lack of these factors, small farmers in rural areas are often excluded from the global retail markets and therefore unable to enjoy benefits that the global procurement system can provide.

In response to the difficulties that small farmers face, empirical studies suggest mechanisms that assist small farmers' participation in the global supply chain. For instance, Hellin et al. (2009) and Narrod et al. (2009) show the importance of collective actions by looking at cases in Central America, and Kenya and India, respectively. By forming farmer organizations, individual smallholders can conduct product marketing as a group, enabling access to improved market information as well as sales of larger quantities which can reduce transaction costs. Minten et al. (2009) argue that intensive farm technical assistance allows farmers to meet complex quality requirements imposed by buyers. They find that participating farmers in Madagascar are provided with necessary inputs by the buyer to ensure the quality of final products. Based on a negative experience in the pineapple industry in Ghana, Whitfield (2012) also highlights the importance of updating production technology as well as trade-friendly policy environments.

In essence, such mechanisms aim to reduce the transactions costs that smallholders face when accessing markets. Transactions costs are seen as one of the key factors that influence market participation and welfare of small farmers (Pingali \& Khwaja, 2005; Barrett, 2008). Poor infrastructure in rural areas in particular can prevent smallholders in developing countries from participating in market-based economic activities (Mabaya, 2003; Moser et al., 2009). At the macro-level, geographically isolated areas demonstrate less market integration than those that are well-connected (Ravallion, 1986; Barrett, 1996; Baulch, 1997; Fackler \& Goodwin, 2001). Rapsomanikis et al. (2006) show that high transfer costs due to poor infrastructure and lack of

\footnotetext{
2 This paper is a joint work with Pamela Alejandra Velasco Pacheco and Stephan von Cramon-Taubadel at the University of Göttingen. The manuscript was submitted to Agricultural Economics in April, 2015.
} 
communication can create large marketing margins. Renkow et al. (2004) estimate that fixed transaction costs are equivalent to a $15 \%$ ad valorem tax on maize farmers in Kenya, and Jacoby and Minten (2009) show that transportation cost can be up to $50 \%$ of final product price in the case of rice farmers in remote areas of Madagascar. As a result, high transportation costs encourage farmers in rural areas to stay in subsistence farming (Dillon \& Barrett, 2013; Key et al., 2000).

When markets are isolated, local players such as traders can acquire regional monopsony or oligopsony power (Barrett, 2008; Faminow \& Benson, 1990; Graubner et al., 2011). As a result, commodity prices in geographically segregated areas often respond less quickly to changes in macro-level prices and are less integrated than in markets that are well linked to national and international markets (Getnet et al., 2005; Goletti et al., 1995; Siqueira et al., 2010). In dealing with market participants who have market power, smallholders will tend to pay more for inputs and receive less for their products, thus exacerbating the problem of low margins and poverty traps.

All of these considerations underline the recognized importance of transportation infrastructure improvement (Jacoby, 2000). Given the potential for infrastructure development in rural areas to alleviate poverty, there is an increasing interest in developing rural infrastructure (World Bank, 2007). However, quantifying the optimal level of infrastructure investment is a difficult task.

If policy makers ignore the effect of market segregation due to transportation cost on low farm prices, the optimal level of investment can be underestimated (Mérel et al., 2009). In order to take appropriate investment decisions, policy makers require quantitative information on the potential effect of rural road improvement. In this chapter we generate such information by studying how farm-gate prices are affected by physical distance and traveling time from farms to markets. Building up on the hedonic price model, we identify product-, producer- and marketing-attributes, including physical distance and traveling time, which influence producer prices.

As a case study, we select the bean sector in rural Nicaragua. Bean is one of the most important crops for food security in Nicaragua besides maize and rice (FAO, 2012; INIDE, 2011). In the recent years, Nicaraguan bean sector suffered from stagnation of productivity and restriction of agricultural land expansion (FAO, 2012). In addition, as a key staple crop, beans are subject to government policy interventions that have arbitrary effects on bean producers. During 2010 and 2011, export restrictions were put in place by the government. This interrupted trade flows to major importers in neighboring Central American countries (FAO, 2012; La Prensa, 2011). Moreover, transportation costs within Nicaragua are high: on average, transportation costs within Nicaragua to local seaports account for $50 \%$ of total freight rates to the U.S. (World Bank, 2012). As a result, bean producers face difficulty in participating in commercial sales, particularly marginalizing those in remote areas. Our paper analyzes factors that influence producer prices of beans in Nicaragua. We pay particular attention to the role played by infrastructure and geographical location.

The rest of the chapter is organized as follows. The next section describes the bean sector in Nicaragua. In section 2.3, we then explain our conceptual framework, data set and econometric 
model. Descriptive statistics and regression results are presented in section 2.4, and we discuss the findings and conclude in section 2.5 .

\subsection{Background}

Beans are important for Nicaraguans not only as a staple food crop but also as a major income source for the poor (FAO, 2012; INIDE, 2011). Beans are produced throughout the country and especially in the Northwest (FAO, 2012). More specifically, production of beans is prominent in the departments $^{3}$ of Jinotega, Matagalpa and Nueva Segovia (INIDE, 2011).

Nicaragua's bean production is predominantly conducted by small producers. Approximately 50\% of bean producers in the country farm less than 7 ha ${ }^{4}$ of land (Table 2.1). These small bean producers account for $30 \%$ of the land used for bean production. Considering that at the national level only $6 \%$ of total agricultural land is farmed by those who own less than 7ha of land (INIDE, 2011), beans are more important to small producers than other commodities. The bean sector has seen little improvement regarding production technology (FAO, 2012). As a result, yield growth has been stagnant over the last 20 years (FAO, n.d.).

Table 2.1. Farm size and number of bean producers in Nicaragua: 2011

\begin{tabular}{lcccccc}
\hline $\begin{array}{l}\text { Size } \\
(\text { Ha) }\end{array}$ & Number & $\%$ & Cumulative \% & Ha & $\%$ & Cumulative \% \\
\hline$<0.4$ & 1,583 & 1.1 & 1.1 & 279 & 0.1 & 0.1 \\
$0.4-0.7$ & 5,176 & 3.8 & 4.9 & 1,796 & 0.8 & 0.9 \\
$0.7-1.8$ & 19,749 & 14.3 & 19.2 & 12,658 & 5.6 & 6.5 \\
$1.8-3.5$ & 20,934 & 15.2 & 34.4 & 21,411 & 9.5 & 16.0 \\
$3.5-7$ & 20,978 & 15.2 & 49.6 & 29,056 & 12.9 & 28.9 \\
$7-14$ & 19,558 & 14.2 & 63.8 & 33,696 & 14.9 & 43.8 \\
$14-35$ & 25,060 & 18.2 & 82.0 & 51,558 & 22.8 & 66.6 \\
$35<$ & 24,841 & 18.0 & 100.0 & 75,508 & 33.4 & 100.0 \\
\hline Total & 137,879 & 100.0 & --- & 225,962 & 100.0 & --- \\
\hline
\end{tabular}

Source: (INIDE, 2011)

The majority of beans produced in Nicaragua are sold domestically but the export market has grown in the last decade (Figure 2.1). Between 2007 and 2010, on average 30\% of total production was directed to the export markets (FAO, n.d.-a). Central American countries are the biggest importers of Nicaraguan beans (Table 2.2). Since 2007, Nicaraguan exports to El Salvador, Costa Rica and Honduras have increased. El Salvador is now the largest importer of beans produced in Nicaragua,

\footnotetext{
${ }^{3}$ Geographical unit goes from departments, municipalities, and communities with departments being the largest units.

${ }^{4}$ In Nicaragua, land area is measured using Manzanas (Mz). 1 Mz=0.704ha.
} 
while a relatively small share is directed to the U.S. The active exchange of the commodity in the Central American region may be due to the Dominican Republic-Central America Free Trade Agreement (DR-CAFTA) signed by the Dominican Republic, the U.S. and Central American nations including Nicaragua in 2004 (USTR, n.d.). Bean exports to Venezuela have also grown since 2008 (Table 2.2).

Figure 2.1. Production, domestic supply and trade of beans in Nicaragua: 2000-2011

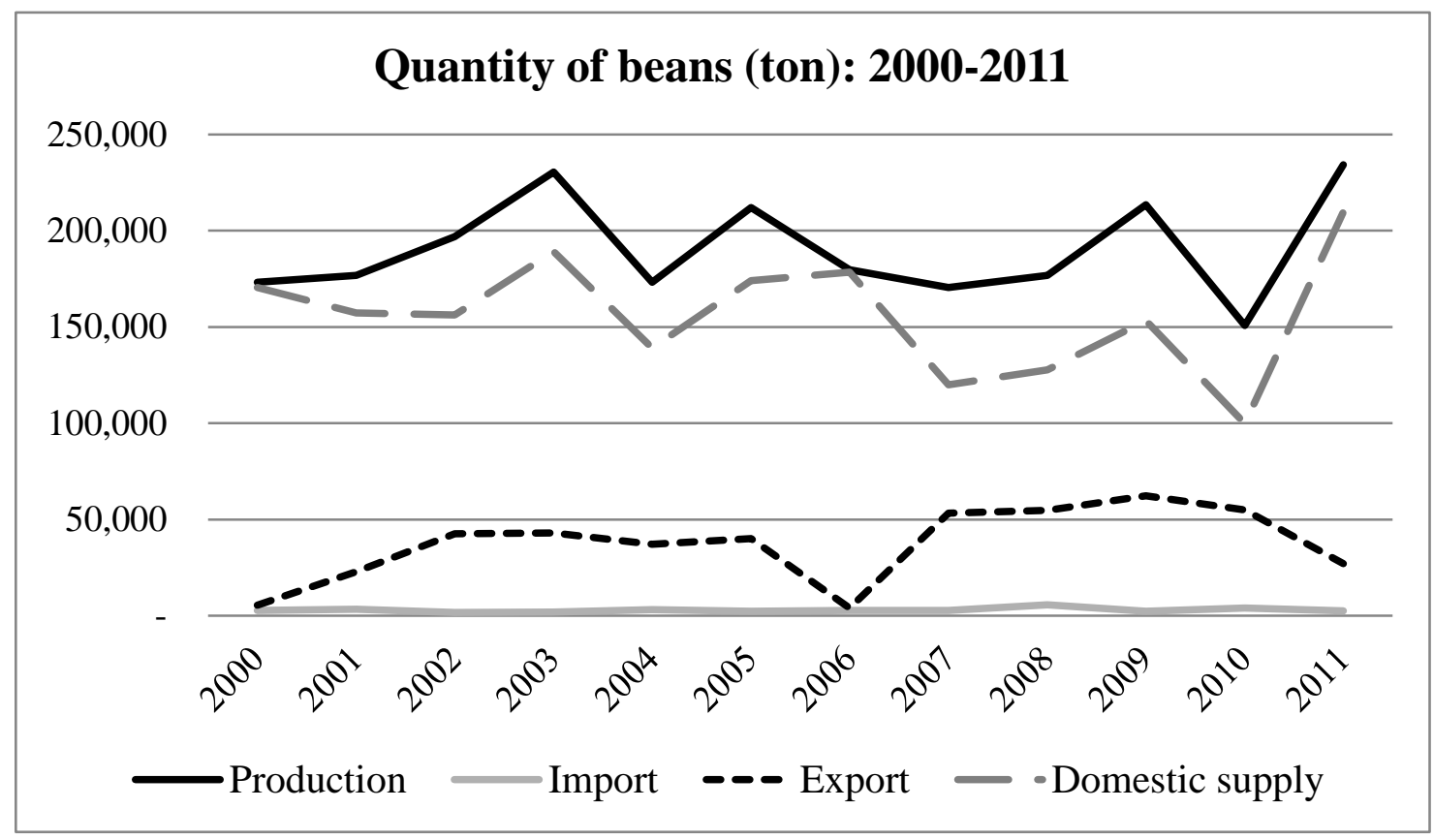

Source: (FAO, n.d.-a)

Two types of beans are produced in Nicaragua: red and black. Red beans are a staple commodity not only in Nicaragua but also in many other Central American countries. Therefore, production of red beans is significantly more than black beans. Although black beans may be exchanged domestically and regionally, they are mostly targeted for export to Venezuela (FAO, 2012). However, the sustainability as well as the potential of the Venezuelan market is questioned. Nicaragua and Venezuela do not have an official trade agreement such as DR-CAFTA, and exports to Venezuela are coordinated exclusively by the Nicaraguan government as a part of an alliance called ALBA (Bolivarian Alliance for the Peoples of Our America, Spanish acronym) (FAO, 2012). As a result, the transactions lack transparency (COHA, 2010) and there are concerns that the recent surge in black bean export to Venezuela may be temporary and do not provide income-generating opportunity for all producers.

As a key food security crop, beans are subject to policy interventions in Nicaragua. In 2010 and 2011, an informal restriction was put on red bean export in order to protect consumers in Nicaragua (The Economist, 2011). However, this policy was criticized for reducing Nicaragua's share of the 
regional red bean market (FAO, 2012; La Prensa, 2011). As seen in Table 2.2, bean export to El Salvador, Costa Rica and Honduras decreased significantly in 2010 and 2011. The resulting shortage of red beans in these Central American markets has been replaced by competitors such as China (FAO, 2012), which could result in Nicaragua losing these markets permanently.

Table 2.2. Destination of Nicaraguan bean export

\begin{tabular}{lcccccc}
\hline Destination & 2006 & 2007 & 2008 & 2009 & 2010 & 2011 \\
\hline North America & & & & & & \\
USA & 3,744 & 3,789 & 5,523 & 5,732 & 4,886 & 2,540 \\
Canada & & & & 80 & & 20 \\
\hline Central America & & & & & & \\
Guatemala & 225 & 496 & 259 & 832 & 472 & 683 \\
El Salvador & & 21,710 & 27,253 & 25,149 & 18,306 & 9,713 \\
Costa Rica & & 17,981 & 14,264 & 14,525 & 12,675 & 3,766 \\
Honduras & & 9,231 & 6,682 & 13,522 & 4,654 & 536 \\
Panama & & & 0 & 20 & 0 & 0 \\
\hline Others & & & & & & \\
Venezuela & & & 660 & 2,460 & 14,040 & 9,806 \\
\hline
\end{tabular}

Source: (FAO, n.d.-a)

Transportation costs are considered as one of the key factors that hinder both international and domestic product exchange in Nicaragua. According to World Bank (2012), Nicaraguan domestic transportation costs can make up more than $50 \%$ of the total freight costs to the U.S. For instance, transportation costs incurred within Nicaragua from Matagalpa, Jinotega and Nueva Segovia to the port of Corinto are 59\%, 62\% and 64\%, respectively, of the total freight costs from these locations to Miami.

In summary, beans are important for smallholders in Nicaragua, many of whom live in remote areas without satisfactory transportation infrastructure. Accessibility to commercial markets differs significantly based on location. Our study intends to understand the role of transportation infrastructure to reach commercial markets in determining producer prices of beans. The next section explains our estimation strategy and the data that we employ.

\subsection{Empirical estimation strategy}

\subsubsection{Conceptual framework}

Our model is based on the hedonic price model developed by Rosen (1974). The hedonic price model decomposes observed market prices based on implicit characteristics of the goods exchanged. This model enables us to isolate product attributes of interest and assess how they influence market prices. 
In the context of agricultural commodities, the hedonic price model has been mainly used to analyze consumer preferences for product attributes. For instance, a number of hedonic analyses of coffee prices have been published (e.g. Donnet et al., 2007, 2008; Teuber \& Herrmann, 2012). Faye et al. (2004) and Mishili et al. (2009) look at cowpea prices in Senegal and Nigeria, Ghana and Mali, respectively. These studies analyze consumer preferences for individual products attributes in order to understand the factors that influence consumer choices. Our study applies an analogous methodology to disentangle product characteristics that influence prices received at the farm level. To the best of our knowledge, this is the first study to employ the hedonic price model in the context of producer prices.

Mathematically, the model is written as:

$P_{i t}=f\left(X_{j t}\right)+\varepsilon_{i t}$

where $P_{i t}$ is the prices received by producer $i$ at time $t$; the $X_{i t}$ is a vector of covariates that explain producer prices; and $\varepsilon_{i t}$ is the error term. We present possible covariates below and econometric issues will be discussed in the econometric model section.

Based on findings from the literature and the empirical context of Nicaraguan bean sector, we identify several variables that are potentially important determinants of farm-gate bean prices. Product quality is one of the most well-documented factors that influence prices (Donnet et al., 2007; Faye et al., 2004; Mishili et al., 2009). Quality characteristics can be implicit (e.g. reputation, brand, preferred production practices) or explicit (e.g. color, shape, size, taste). Marketing practices are often found to be important as well. In their consumer price study, Donnet et al. (2007) show that a large quantity decreases product prices. This may be because sellers are willing to give discount for a larger quantity of sales. However, we note that producer prices may increase with an increase in quantity exchanged since a large seller may be able to take advantage of the leverage. Gender might also play a role as female farmers may have less negotiation power than men and can face disadvantages when marketing (Dolan, 2001; Zhang et al., 2006). As a result, they may receive lower prices than their male counterparts.

Distance and lack of access to markets can have negative effects on producer prices. For instance, Fafchamps and Hill (2005) show that coffee producers in Uganda are offered lower prices by traders in their villages than at commercial markets due to the cost of traveling to remote villages. In addition, remoteness can reduce competition and enable oligopsonistic traders to offer lower farm-gate prices (Graubner et al., 2011). Michelson et al. (2012) show that farm-gate prices are significantly lower than wholesale prices in the capital city in Nicaragua. This may result from the exploitation of market power by traders in farming communities when individual transportation to commercial markets is not easy due to poor transportation infrastructure.

Based on these considerations, we employ various measures of product quality, quantity exchanged and transfer costs to major ports as explanatory variables in our analysis. We use total distance and traveling time between farming communities and commercial markets as proxies for transfer costs. 
No matter who travels the distance, farm-gate prices are set lower if the overall transfer costs are high. Therefore, our analysis applies total distance and traveling time from communities to major commercial centers instead of markets where producers could sell their products.

\subsubsection{Data}

We analyze sales data recorded by CRS. CRS implemented a development project in rural Nicaragua between September 2007 and October 2012. This project targeted small farmers in Nicaragua who own less than 10 hectares of land. Among the information that was collected are records of individual sales by farmers over the five-year project period. In total, there are 3,893 bean producers in the data. Each producer sold beans at least once during the five years and the average producer sold beans three times, which sums up to a total of 11,719 observations. We exploit the full unbalanced panel data set.

The farmers included in the data set were not chosen randomly. Instead, CRS applied several criteria in selecting individuals to participate in its project ${ }^{5}$. However, the project did not include any interventions that directly influence farm-gate prices. Moreover, the information provided by CRS is rich in the factors that may influence farm-gate prices. The credibility of the information is high since the information on sales was collected every three months, which is approximately one cultivation cycle of beans. Price data are available for each individual sales transaction and include information on the buyers, destination countries, and product quality.

The dependent variable, the farm-gate prices of beans, was originally recorded in the local currency, Nicaraguan Córdobas. We converted the values to USD to facilitate result interpretation, using the exchange rates recorded throughout the project period. Our explanatory variables are transfer cost, and both non-binary and binary variables which are categorized as marketing-, product-, and farmer-related variables.

The exact location of each farm is not coded in the dataset, but for each farm we do know in which municipality it is located. Our data represent 54 out of a total of 153 municipalities in Nicaragua. The 54 municipalities on average each extend over $571 \mathrm{~km}^{2}$, and most do not extend over $40 \mathrm{~km}$ in the longest dimension, while the distance to commercial markets range between $156 \mathrm{~km}$ and $690 \mathrm{~km}$. While we are confident that the municipality provides a good first approximation of a farm's location, GPS data would clearly facilitate future research. For each farm we calculate distances and traveling time between three major commercial centers and the center of communities in each municipality in which it is located using Google Maps. Both measurements are used since using only distances may not capture the quality of roads.

The three commercial centers are identified in terms of national and international product exchange: namely, Managua international airport, the Port of Corinto and the Port of Limón. The Port of

\footnotetext{
${ }^{5}$ The details of the selection criteria are explained in Section 6.1.
} 
Limón is the major seaport in Costa Rica while the Port of Corinto is in Nicaragua. In terms of Nicaragua's total export values, 30\%, 15\% and 14\% are exchanged annually from Port of Corinto, Port of Limón and Managua international airport, respectively (Figure 2.2). As the nation's capital, Managua is an important point of commercial exchange for domestic consumption of beans. Thus we include Managua even though it is unlikely that beans are exported by air.

Figure 2.2. Share of value exported from various ports in Central America

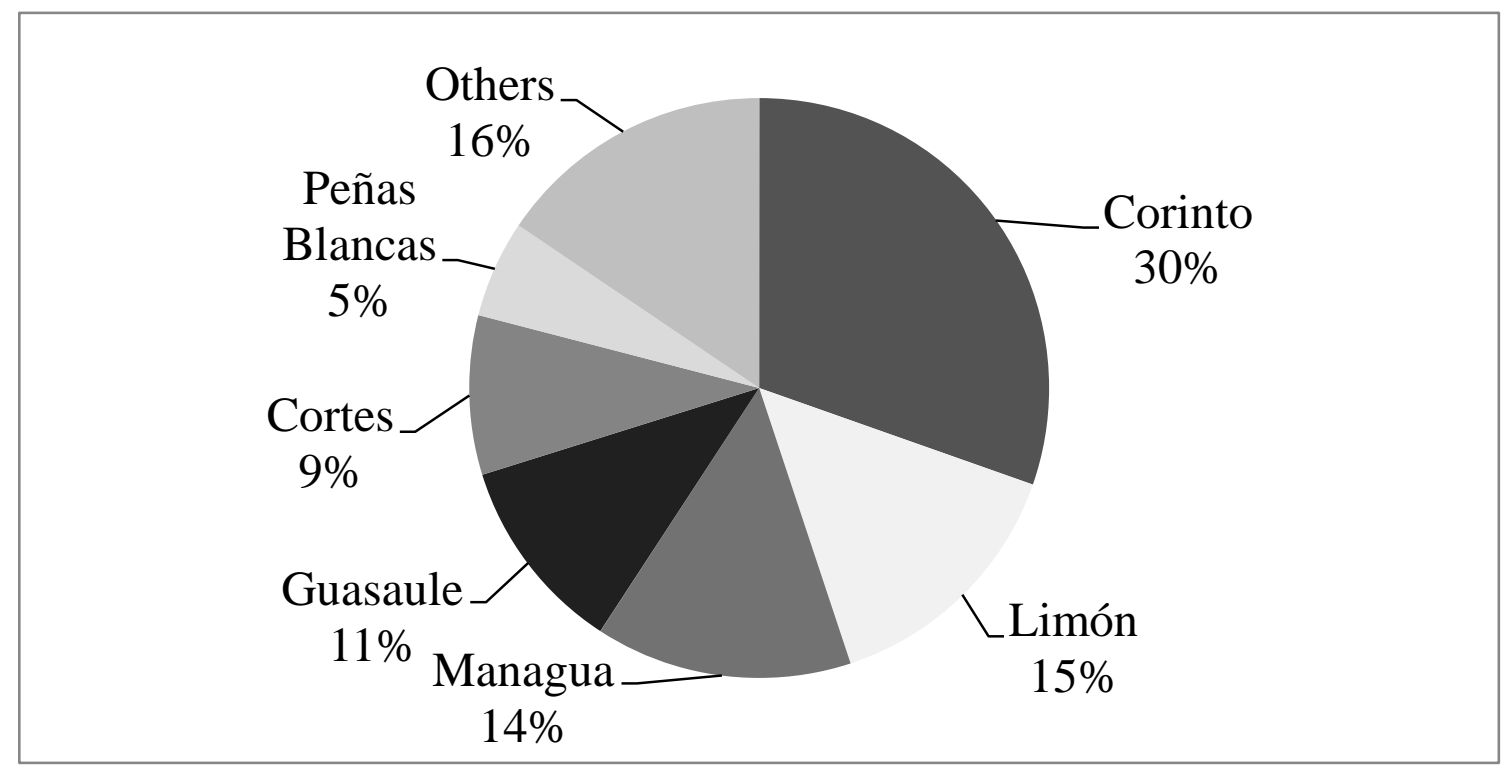

Source: (CETREX, 2015)

For marketing-related variables, we use information about buyers and the intended destination of the beans exchanged. Buyers are divided into five categories: local markets, intermediaries, farmer organizations/cooperatives, private companies, and private export companies. In the analysis, we drop the dummy variable representing local markets as a point of comparison. We expect product prices to be higher when the buyer is a farmer organization/cooperative rather than the local market or a private company. This is because cooperatives' main objective is not profit but rather enhancing members' welfare (Giannakas \& Fulton, 2005). The information regarding destination countries was obtained through cooperatives. Approximately $90 \%$ of farmers in the sample belong to a cooperative and these cooperatives are aware of all the buyers outside local wholesale markets. Therefore, the cooperatives provided information regarding product destination countries corresponding to each buyer. All of the beans sold are destined for the domestic Nicaraguan market or for export to Costa Rica, El Salvador or Venezuela. In order to test whether prices differ by destination, we apply one dummy variable for each of the export destinations. Hence, the default destination is the domestic market in Nicaragua. While it is possible beans destined for export markets fetch higher prices, in the case of Venezuela the prices may be lower due to an agreement 
between the governments. Therefore, the expected effect of these destination dummy variables is unclear a priori.

For product-related variables, we apply product quality and variety. The quality variable is recorded as 1 if the bean sold is of a high quality. According to the NGO, quality was determined mainly based on grain size ${ }^{6}$. The variety variable equals 1 if the bean sold is red bean and 0 if it is black bean. We expect that the higher the quality of the product, the higher its price (Donnet et al., 2007; Faye et al., 2004; Mishili et al., 2009). Therefore, the quality variable is expected to have a positive coefficient. In terms of bean variety, red beans may receive higher and more volatile prices than black beans because black bean prices may be regulated by the Nicaraguan and Venezuelan governments while red bean prices are determined freely in the market.

For farmer-related variables, we employ two farmer characteristics variables: gender and household head. Gender of the producer is recorded as 1 if female and 0 if male. The household head variable equals 1 if the producer is the head of the household. The gender variable will have a negative coefficient if females face disadvantage when marketing compared with males (Dolan, 2001; Zhang et al., 2006). The effect of being a household head on producer prices is ambiguous.

\subsubsection{Econometric model}

In order to quantify how physical distance affects farm-gate prices in our panel data, we estimate a double log random-effects model. We conclude that this model is appropriate based on several diagnostic tests. First, we test for omitted variables problem and heteroskedasticity following Ramsey (1969) and Breusch \& Pagan (1979), respectively. We find that pooled OLS estimation yields omitted variable problems and our data demonstrate heteroskedasticity. To mitigate the heteroskedasticity problem, we report heteroskedasticity-robust variances throughout. The omitted variable problems can be solved by exploiting the panel nature of our data set (Wooldridge, 2010). We use the random-effects model as our main interest lies in the distance and travel time variables, which are time-invariant.

Second, we test whether our dependent variable, farm-gate prices, is normally distributed. In Figure 2.3, we see that the distribution is skewed to the left and has several kinks. Diagnostic tests suggested by D'agostino et al. (1990) and Royston (1992) confirm that the distribution is skewed and displays non-normal kurtosis. Therefore, we transform the dependent variable by taking a logarithm, and by applying a theta value estimated by the Box-Cox method. Both of these transformations yield normality in terms of skewness. We select the logarithmic transformation because the double-log model allows us to interpret estimated coefficients as elasticities.

\footnotetext{
${ }^{6}$ Generally speaking, international markets only accept "first grade", or high quality, and the lowest quality (below third grade) goes to animal feed. Beans that are not sold to international markets or feed processors are processed for human consumption or sold at local markets where the food quality standard is low.
} 
Figure 2.3. Distribution of farm-gate prices

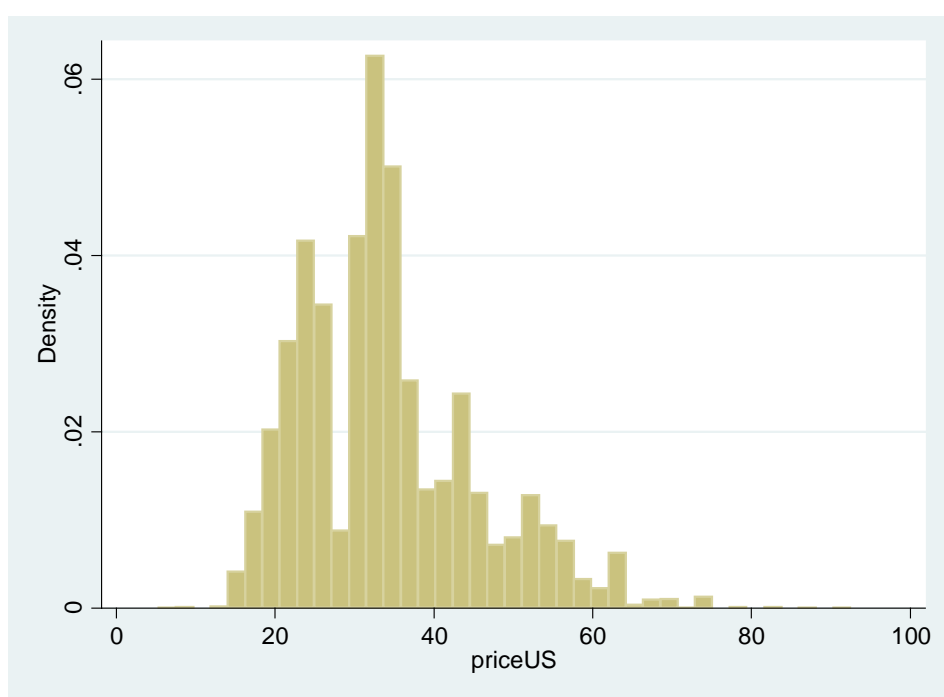

Source: Authors’ calculation

Hence, we estimate the following specification of the model outlined in equation (2.1):

$\ln P_{i t}=\alpha+\beta_{1} \ln C_{i}+\beta_{2} \ln Q_{i t}+\gamma_{j} \sum_{j=1}^{J} X_{j t}+\xi_{t}+u_{i t}$

where $P_{i t}$ is the farm-gate prices received by farmer i at time $\mathrm{t}$; $\mathrm{TC}_{\mathrm{i}}$ is the transfer cost (distance or time traveled to markets) between the municipality that farmer i lives in and the commercial center; $\mathrm{Q}_{\mathrm{it}}$ is the quantity of beans sold; the $\mathrm{X}_{\mathrm{jt}}$ are other characteristics that influence farm-gate prices; $\xi_{\mathrm{t}}$ are year dummies; and $u_{i t}$ is the error term. The covariates in $\mathrm{X}_{\mathrm{jt}}$ include buyers (intermediaries, farmer organizations/cooperatives, private companies, private export companies), countries to which products were sold to (Costa Rica, El Salvador, Venezuela), product characteristics (product quality, red beans), and farmer characteristics (gender and head of the household).

\subsection{Estimation results}

Table 2.3 presents descriptive statistics for our data set. On average, the price of a quintal (qq) of beans is 34.13USD over all observations (see also Figure 2.3). A farmer sells about 21qq in one sales transaction while incurring 32.23USD of production costs. This generates 689.68USD of profit on average per sales transaction. Annually, a representative farmer produces 28.51qq of beans and incurs 43.79USD of production cost. The mean annual profit of all producers in the sample is 937.01USD per year. The annual profit ranges between -261USD and 18,319USD.

Few farmers sell their products at non-local markets: only about $7 \%$ of producers sell to intermediaries, farmer organizations, and private companies. $14 \%$ of the producers are female and about half are heads of a household. Nearly $80 \%$ of the products were of high quality and $92 \%$ of 
products were red beans. Small percentage of produce is exported: approximately 8\% to Costa Rica, El Salvador and Venezuela together.

Table 2.3. Descriptive statistics

\begin{tabular}{|c|c|c|c|c|}
\hline & Mean & S.D. & Min & Max \\
\hline Price of beans(USD/qq*) & 34.13 & 11.21 & 5.3 & 93 \\
\hline Quantity(qq) & 20.99 & 24.96 & 0.5 & 416 \\
\hline Total production cost(USD) & 32.23 & 39.45 & 0.5 & 739 \\
\hline Profit/sale(USD) & 689.68 & 890.16 & -396.4 & 13,394 \\
\hline Annual quantity/producer(qq) & 28.51 & 33.71 & 0.5 & 476 \\
\hline Annual production cost/producer(USD) & 43.79 & 52.20 & 0.7 & 1,109 \\
\hline Annual profit/producer(USD) & 937.01 & $1,212.21$ & -260.8 & 18,319 \\
\hline Intermediary & 0.03 & 0.18 & 0.0 & 1 \\
\hline Organization & 0.00 & 0.04 & 0.0 & 1 \\
\hline Private company & 0.02 & 0.15 & 0.0 & 1 \\
\hline Private-export company & 0.02 & 0.13 & 0.0 & 1 \\
\hline Quality: first & 0.79 & 0.40 & 0.0 & 1 \\
\hline Gender & 0.14 & 0.35 & 0.0 & 1 \\
\hline Head of family & 0.53 & 0.50 & 0.0 & 1 \\
\hline Red bean & 0.92 & 0.26 & 0.0 & 1 \\
\hline Costa Rica & 0.02 & 0.13 & 0.0 & 1 \\
\hline El Salvador & 0.03 & 0.17 & 0.0 & 1 \\
\hline Venezuela & 0.03 & 0.16 & 0.0 & 1 \\
\hline \multicolumn{5}{|l|}{ Distance $(\mathrm{km})$ from municipalities to } \\
\hline Managua & 156.28 & 48.66 & 82 & 284 \\
\hline Port of Corinto & 212.63 & 44.81 & 157 & 418 \\
\hline Port of Limón & 690.08 & 49.15 & 444 & 818 \\
\hline \multicolumn{5}{|l|}{ Travel time (minutes) by motor vehicle to } \\
\hline Managua & 133.17 & 41.60 & 68 & 242 \\
\hline Port of Corinto & 183.24 & 41.78 & 127 & 362 \\
\hline Port of Limón & 596.04 & 41.54 & 386 & 705 \\
\hline
\end{tabular}

*Nicaraguan quintales. $1 \mathrm{qq}=100 \mathrm{lbs}$ or approximately $45 \mathrm{~kg}$.

Source: Authors' calculation

On average, producers are located at a distance of $156 \mathrm{~km}, 213 \mathrm{~km}$ and $690 \mathrm{~km}$ from Managua airport, the Port of Corinto and the Port of Limón, respectively. This confirms that the error introduced by using municipality rather than exact location for each farm is comparatively small. The average traveling times are 133, 183 and 596 minutes for Managua airport, the Port of Corinto and the Port of Limón, respectively. 
Table 2.4 shows the estimated coefficients for all models. Overall the regressions are able to explain roughly one-half of the variation in the observed farm-gate prices. Most of our expectations are met. A one percent increase in quantity exchanged reduces farm-gate prices by $0.01 \%$. For an average farmer, it is equivalent to a decrease by 0.3 cents/qq. While the coefficients in all models are statistically significant and negative, the magnitude of the effect is relatively small.

As expected, farmer organizations offer higher prices than local markets, while private companies offer less. Product quality is strongly and statistically significantly linked to higher farm-gate prices, which is consistent with the findings from the empirical literature. The magnitude of the effect highlights the importance of quality attribute in determination of bean prices compared with other variables. First quality products receive $0.54 \%$ higher prices than the rest, which is approximately 18 cents/qq for an average exchange. Female sellers tend to receive lower prices than males, and household heads are likely to receive higher prices than non-household heads. Red beans are associated with higher prices than black beans. Prices of beans for the Costa Rican market tend to be lower than those that stay in Nicaragua. This might be due to their preference for black beans (Rodríguez Lizano, 2014). While the Salvadorian market offers higher prices than in Nicaragua, the coefficient for Venezuela is not statistically significant ${ }^{7}$.

Regarding the estimated coefficients of distances, our main interest, all coefficients are negative and statistically significant. This indicates that a longer distance to the points of commerce is associated with a decrease in farm-gate prices. A one-percent increase in the distance to Managua, Corinto and Limón is associated with a $0.07 \%, 0.13 \%$ and $0.32 \%$ decrease in farm-gate prices, respectively. Evaluated at mean values, these estimated distance effects are equivalent to price reductions of 2 cents per qq and km of distance.

How does the message change if time traveled is taken into account rather than physical distance? Overall the results are very similar in all important respects. The signs of the coefficients of the time variable are negative and statistically significant. The result indicates that a one-percent increase in time traveled to the three locations is associated with a decrease in farm-gate bean prices by $0.10 \%$, 0.15\% and $0.45 \%$ for Managua, Port of Corinto and Port of Limon, respectively. Hence, on average a one-minute reduction in time traveled is associated with an increase in the bean price by approximately 2.5 cents per qq.

\footnotetext{
${ }^{7}$ Since Venezuela imports only black beans, there may be multicolinearity between the variables "Venezuela", "Private company", "Export company", and "Red bean". We tried excluding "Venezuela" from all estimations but omitting the variable does not change the results in terms of both signs and statistical significance.
} 
Table 2.4. Regression results (t-values in brackets)

\begin{tabular}{|c|c|c|c|c|c|c|}
\hline & \multicolumn{3}{|c|}{ Distance (km) } & \multicolumn{3}{|c|}{ Travel time (minutes) } \\
\hline & Managua & Corinto & Limón & Managua & Corinto & Limón \\
\hline \multirow[t]{2}{*}{ Quantity } & -0.01 & -0.01 & -0.01 & -0.01 & -0.01 & -0.01 \\
\hline & $(3.96)^{* * *}$ & $(4.69) * * *$ & $(4.01)^{* * *}$ & $(4.59) * * *$ & $(5.33) * * *$ & $(4.68)^{* * *}$ \\
\hline \multirow[t]{2}{*}{ Intermediary } & -0.03 & -0.02 & -0.03 & -0.02 & -0.01 & -0.02 \\
\hline & $(4.49)^{* * *}$ & $(1.96)^{* *}$ & $(4.21)^{* * *}$ & $(3.17)^{* * *}$ & $(1.34)$ & $(3.02)^{* * *}$ \\
\hline \multirow[t]{2}{*}{ Organization } & 0.12 & 0.13 & 0.12 & 0.14 & 0.16 & 0.13 \\
\hline & $(7.77)^{* * *}$ & $(9.12)^{* * *}$ & $(7.77)^{* * *}$ & $(7.72)^{* * *}$ & $(9.39)^{* * *}$ & $(7.76)^{* * *}$ \\
\hline \multirow[t]{2}{*}{ Private company } & -0.10 & -0.09 & -0.10 & -0.10 & -0.09 & -0.10 \\
\hline & $(6.67)^{* * *}$ & $(6.00)^{* * *}$ & $(6.65)^{* * *}$ & $(6.16)^{* * *}$ & $(5.62)^{* * *}$ & $(6.21)^{* * *}$ \\
\hline \multirow[t]{2}{*}{ Export company } & -0.00 & 0.01 & -0.00 & 0.00 & 0.02 & 0.00 \\
\hline & $(0.03)$ & $(0.50)$ & $(0.02)$ & $(0.07)$ & $(0.96)$ & $(0.18)$ \\
\hline \multirow[t]{2}{*}{ Quality: first } & 0.54 & 0.54 & 0.54 & 0.54 & 0.54 & 0.54 \\
\hline & $(29.79)^{* * *}$ & $(29.50)^{* * *}$ & $(29.85)^{* * *}$ & $(29.53)^{* * *}$ & $(29.13)^{* * *}$ & $(29.57)^{* * *}$ \\
\hline \multirow[t]{2}{*}{ Sex } & -0.02 & -0.02 & -0.02 & -0.02 & -0.02 & -0.02 \\
\hline & $(4.09)^{* * *}$ & $(3.98)^{* * *}$ & $(3.98)^{* * *}$ & $(3.65)^{* * *}$ & $(3.61)^{* * *}$ & $(3.64) * * *$ \\
\hline \multirow[t]{2}{*}{ Head of family } & 0.04 & 0.04 & 0.04 & 0.04 & 0.04 & 0.04 \\
\hline & $(8.31)^{* * *}$ & $(8.82)^{* * *}$ & $(8.59) * * *$ & $(8.83)^{* * *}$ & $(9.12)^{* * *}$ & $(9.11) * * *$ \\
\hline \multirow[t]{2}{*}{ Red bean } & 0.13 & 0.13 & 0.13 & 0.13 & 0.12 & 0.13 \\
\hline & $(13.56)^{* * *}$ & $(13.44)^{* * *}$ & $(13.64)^{* * *}$ & $(13.01)^{* * *}$ & $(12.84)^{* * *}$ & $(13.23)^{* * *}$ \\
\hline \multirow[t]{2}{*}{ Costa Rica } & -0.10 & -0.09 & -0.09 & -0.09 & -0.10 & -0.09 \\
\hline & $(6.50)^{* * *}$ & $(6.81)^{* * *}$ & $(6.57)^{* * *}$ & $(6.72)^{* * *}$ & $(7.32)^{* * *}$ & $(6.81)^{* * *}$ \\
\hline \multirow[t]{2}{*}{ El Salvador } & 0.24 & 0.26 & 0.25 & 0.25 & 0.26 & 0.25 \\
\hline & $(32.88)^{* * *}$ & $(31.38)^{* * *}$ & $(33.10)^{* * *}$ & $(33.13)^{* * *}$ & $(32.53)^{* * *}$ & $(33.44)^{* * *}$ \\
\hline \multirow[t]{2}{*}{ Venezuela } & -0.01 & -0.01 & -0.01 & -0.01 & -0.02 & -0.01 \\
\hline & $(0.70)$ & $(0.73)$ & $(0.65)$ & $(0.63)$ & $(0.98)$ & $(0.62)$ \\
\hline \multirow[t]{2}{*}{ Transfer cost } & -0.07 & -0.13 & -0.32 & -0.10 & -0.15 & -0.45 \\
\hline & $(7.85)^{* * *}$ & $(10.12)^{* * *}$ & $(8.72)^{* * *}$ & $(12.45)^{* * *}$ & $(13.56)^{* * *}$ & $(12.88)^{* * *}$ \\
\hline \multirow[t]{2}{*}{ Constant } & 3.39 & 3.75 & 5.12 & 3.53 & 3.82 & 5.94 \\
\hline & $(76.67)^{* * *}$ & $(54.21)^{* * *}$ & $(21.58)^{* * *}$ & $(87.34)^{* * *}$ & $(66.65)^{* * *}$ & $(26.55)^{* * *}$ \\
\hline $\mathrm{R}^{2}$ & 0.49 & 0.50 & 0.50 & 0.50 & 0.50 & 0.50 \\
\hline
\end{tabular}

*** $p<0.05 ; * * * \mathrm{p}<0.01$

Note: Regressions include time (year) fixed effects which are available from the author.

Source: Authors’ calculation 


\subsection{Discussion}

The magnitudes of the estimated distance/travel time effects reported above are reasonable. An interview with CRS staffs revealed that the cost of transporting beans is approximately 4 cents per qq and kilometer. How important are these effects for the participating farmers and the rural communities?

Suppose that the transportation infrastructure improves in the farming communities and as a result the time of transportation decreases by 25\%. In other words, it takes 100, 137 and 447 minutes on average instead of 133, 183 and 596 minutes to go to Managua, Corinto and Limón, respectively. According to our estimates, this would increase revenues from bean sales by $\$ 0.84, \$ 1.26$ and $\$ 3.85$ per qq for sales directed to Managua, Corinto and Limón, respectively ${ }^{8}$. The average farmer in our sample sells 28.51qq of beans yearly. Therefore, assuming that production costs do not change and transportation costs decrease due to road improvement, bean sales profit would increase by at least between $\$ 24$ and $\$ 110$ per year. This ranges between $3 \%$ and $12 \%$ of an average farming household's annual income from bean sales. For the total 11,718 sales transactions in our sample, this translates to an annual income increase of between $\$ 281,232$ and $\$ 1,288,980$.

At the sectorial level, our finding has a larger implication. Our analysis is limited to bean producers in selected regions. Needless to say, bean farmers in our data set produce other crops such as fresh vegetables and fruits. In addition, there are a total of approximately 260,000 agricultural producers throughout Nicaragua according to the national census (INIDE, 2011). The distance effects estimated above will also apply to these other crops and producers. Hence, investments in improved infrastructure such as roads would have a significant effect on agricultural revenues as a whole. This effect should be taken into account when calculating the benefits of infrastructure investment programs.

Note as well that our analysis of benefits to farmers of reducing transport costs does not take externalities into account. Improving rural transportation networks can have both positive and negative effects on rural communities (Straub, 2008, 2011). However, quantifying these effects is challenging (Straub, 2008) and beyond the scope of our research.

We acknowledge that our measure of distance, which is based on the municipality that a farm is located in, is imperfect. Ideally we would use GPS data to locate each farm precisely. While this might increase the explanatory power of our regressions, there is no reason to believe that error in

\footnotetext{
${ }^{8}$ Since we employ log-log model, the relationship between time traveled and producer prices may not be linear throughout observations even if elasticities stay constant. To check this, we calculated the effects at the mean, median, $25 \%$ quantile and $75 \%$ quantile. The results suggest that the price increase corresponding to a $25 \%$ decrease in time traveled would be between $\$ 0.75$ and $\$ 3.21$ at the median, $\$ 0.71$ and $\$ 2.63$ at the 25\% quantile, and $\$ 0.69$ and $\$ 3.74$ at the $75 \%$ quantile. Therefore, we conclude that non-linearity does not affect our results to a large extent.
} 
the measurement of distance biases our results in either direction. We assume that the measurement errors can be both positive and negative, which results in zero bias on average.

\subsection{Conclusions}

In the development literature, smallholders' market participation has attracted attention as a catalyst to poverty. One of the most important factors to enable smallholder marketing is reduction of transaction costs that small producers face in rural areas. Particularly, costs related to transportation have been discussed as important. However, quantification of benefits from improving transportation infrastructure has not been achieved by the empirical literature despite the recognized importance. Our study intends to fill the gap by taking one of the first steps towards understanding the effect of physical distance on farm-gate prices.

Using the data set collected in rural Nicaragua over five years, we estimate a hedonic price model. It enables us to separate attributes of the commodity of interest, staple beans, and understand what characteristics are associated with change in producer prices. We estimate a double-log model, using the random effects panel approach. Our main interest lies in the variable capturing distance and travel time between farming communities and major commercial centers. We selected the airport of Managua and two seaports in Nicaragua and Costa Rica which are important for agricultural marketing and trade. In addition to the distance variable, we employ other characteristics such as product quality and destination countries.

The results indicate that an increase in physical distance is indeed correlated with a decrease in farm-gate prices of beans. More specifically, we find that an increase in distance by $1 \mathrm{~km}$ and travel time by one minute are associated with a decrease in farm-gate prices by 2-2.5 cents. We conclude that annual agricultural income from bean sales would increase by between \$24 and \$110 per year if travel time to markets is reduced by $25 \%$. Considering that improvement in public roads affects multiple sectors and dimensions of poverty alleviation, the seemingly small increase in farm-gate prices can have important effects on rural households' agricultural income.

We acknowledge the limitations of our study. Our findings are limited to road development and do not take other types of transaction costs into account. Moreover, it is beyond the scope of our research to address externalities from rural road development. Therefore, we are not able to provide a comprehensive quantification as to the monetary returns to investment in public roads in rural

areas. While such a task is challenging, further research should address more holistic measure of the benefits associated with development of rural roads. 


\section{NGO Intervention and Market Linkage ${ }^{9}$}

\subsection{Introduction}

In the recent years, the topic of smallholder commercialization has received much attention in the development literature. Smallholders' inclusion in commercial markets can benefit them by providing premium prices (Gulati et al., 2007), reducing transaction costs (Nagaraj et al., 2008; Vieira, 2008), and providing access to credits and improved production technology (Minten et al., 2009; Nagaraj et al., 2008; Swinnen, 2007). However, such emerging market transactions can also pose challenges for smallholder farmers in developing countries. Small farmers may be excluded from these markets due to a lack of assets to meet more stringent standards required in the modern marketing chains, leading to further marginalization of the poor in the developing world (Barrett et al., 2012; Reardon et al., 2003; Reardon et al., 2009; Reardon \& Timmer, 2007; Swinnen, 2007).

However, overcoming the difficulties that resource-poor farmers face is not a straightforward task. While the empirical literature has identified mechanisms that allow smallholder farmers to exploit the business opportunities of agricultural commodity markets (Hellin et al., 2009; Minten et al., 2009; Narrod et al., 2009; Whitfield, 2012), actual enforcement of such mechanisms is difficult particularly when private companies are the sole initiators of the implementation. In general, retail companies systematically prefer farmers with a good access to roads, physical assets (e.g. irrigation system), possession of relatively large land areas and high human capital (e.g. education, experience in horticultural production) (Barrett et al., 2012; Donovan \& Poole, 2008; Michelson, 2013; Rao \& Qaim, 2011). As a result, retail companies-based market linkage tends to be limited to producers who are relatively better off at the initial stage. In addition, even if smallholders are included in the marketing chains at the initial stage, many are unable to maintain participation due to both quality and quantity requirements and implicit risks (Barrett et al., 2012; Donovan \& Poole, 2008).

Having identified the importance of product commercialization as well as the constraints small farmers face, many development institutions are starting to consider assisting smallholder farmers to commercialize as a catalyst for alleviation of rural poverty. A number of development projects have been launched in order to initiate better communication and increased exchange between farmers and buyers in commodity markets (Humphrey \& Navas-Alemán, 2010; Barrett, 2008; Shepherd, 2007). Food and Agriculture Organization of the United Nations (FAO), International Fund for Agricultural Development (IFAD), and the Consultative Group on International Agricultural Research (CGIAR) are amongst the public institutions initiating market linkage programs for smallholder farmers throughout the world (CIAT, n.d.; FAO, n.d.-b; IFAD, 2012).

Despite the recognized potential of projects aiming at linking farmers to markets, there is a lack of empirical literature to address outcomes of intervention activities at the micro-, meso- and macro-

\footnotetext{
${ }^{9}$ This is a joint work with Silke Hüttel at the University of Rostock. 
levels (Barrett, 2008; Mithofer, 2011). To the best of our knowledge, there is no study that explicitly assesses the effects of development projects in the context of smallholder market linkage. While many argue the importance of external support in either establishing or maintaining the industry (e.g. Bignebat \& Vagneron, 2011; Carletto et al., 2011; Kersting \& Wollni, 2012; Subervie \& Vagneron, 2013), there is little constructive argument as to what intervention activities contribute to smallholder commercialization by how much. In addition, existing studies fail to differentiate activities in assessing effectiveness of development projects.

This is an important research gap to be addressed. The existing reports do not provide satisfactory answers as to what extent projects were successful in achieving their objectives, whether the success was due to project interventions, and if the implementation of the projects was cost effective (Humphrey \& Navas-Alemán, 2010). However, such studies are difficult to assess empirically. Product participants are selected according to certain criteria. Therefore, evaluation of the effects of project interventions has to control for potential selection biases, which is challenging (Barrett, 2008). Carrying out such studies can be costly and many organizations prefer to allocate the resources for the actual implementation of the project rather than impact evaluation (Humphrey \& Navas-Alemán, 2010). Moreover, assessment of impact in a long-run requires a panel data set that allows us to control for selection bias and unobserved heterogeneity.

This paper intends to fill the aforementioned gap by investigating how an NGO intervention influences market linkage of smallholder farmers. As a case study, we refer to the identical development project as in Chapter 2 whose focus was market linkage of smallholder farmers. We continue to conduct our analysis on bean farmers.

This paper contributes to the empirical literature in two aspects. The first contribution is to identify pathways that a development project influences smallholder marketing by scrutinizing how interventions with unique objectives affect the volume of bean sales in non-local markets. The project of interest consists of five individual programs, each of which addresses different aspects of production and marketing of agricultural goods. Unlike other studies, this study differentiates activities to better understand what types of intervention activities have effect on product marketing in a rural setting. To the best of our knowledge, there is no study that addresses effectiveness of different NGO-based activities in the context of commercialization of smallholder farmers.

Second, we control for unobserved heterogeneity by exploiting a panel data set. Most studies to date in the smallholder commercialization literature use cross sectional data sets or reconstructed panel data based on recall interviews. Although such studies can provide useful insights for policy makers, the lack of observations over time makes it impossible to control for potential unobservable heterogeneity that is individual-specific. By utilizing a panel data set, we are able to account for such shortcomings.

There are a few reasons why this particular project is chosen. First, CRS has recorded substantial amount of information at the household level over the five years. The information includes detailed 
data at all points of sales that approximately 10,000 producers undertook. CRS recorded the information for every sales transaction ${ }^{10}$, which ensures the reliability of the data. In addition, information about intervention activities is also well recorded. Even though there is a lack of some critical information, such detailed data can provide us useful insights as to how farmers' behavior changed over time in response to what type of intervention activities.

Second, due to the detailed information, we are able to differentiate individual intervention activities with unique objectives. In many of the aforementioned studies, intervention activities are not separated based on categories. However, activities that address productivity increase should not be treated in the same way as those focusing on post-harvest management practices. Also, scrutinizing intervention can point out important aspects that enable small farmers' participation in commercial markets even outside the context of development project intervention. With detailed information about what type of intervention was undertaken by whom, we are able to understand impact pathways for market linkage.

Third, studying this particular project can serve as a model for other market linkage projects that are being launched throughout the world. Linkage-focused interventions such as the Nicaraguan project have become popular amongst donors while evaluation of such programs has not been done in a satisfactory manner (Humphrey \& Navas-Alemán, 2010). Therefore, understanding the effectiveness as well as limitation of such market linkage-oriented projects can help design new projects based on the learnings from this project in Nicaragua.

The rest of the chapter is organized as follows. The next section presents the overview of the market linkage program. Section 3.3 discusses the conceptual framework, data and econometric strategy to analyze the effects of program participation on producers' market linkage. Section 3.4 presents the results, which is further discussed in Section 3.5. Finally, Section 3.6 summarizes and concludes.

\subsection{Background}

Our analysis focuses on activities related to "entrepreneurial practices". The project intervention is first divided into five distinct programs: production program, environmental program, gender program, post-harvest program, and market linkage program. Each program has one or two training categories with distinct themes. Namely, the production program has trainings for agricultural practices and agricultural production, and the environmental program has trainings for water and environmental management. The gender and post-harvest ${ }^{11}$ programs each have one category. The market linkage program is divided into two training categories: "entrepreneurial practices" and "municipality engagement". Our interest lies in eliciting effect of "entrepreneurial practices" activities.

\footnotetext{
${ }^{10}$ As described in Chapter 2, the maximum recall period is three months, one production cycle of beans.

${ }^{11}$ Post-harvest program has, in fact, activities on "post-harvest management” and "manufacturing practices”. However, no bean producer participated in the latter.
} 
Not all project participants received activities in all categories. Table 3.1 shows the number of producers who participated in activities in each program. Among the five programs, the production program was implemented most intensively, followed by the market linkage program and environmental program. Some participants took part in more than one program over time. Therefore, there is an overlap between different programs. Every year, approximately $6 \%$ of all bean producers participated in the market linkage program.

Table 3.1. Number of producers who participated in intervention activities: 2007-2012

\begin{tabular}{lcccccc}
\hline Year/Activity & 2007 & 2008 & 2009 & 2010 & 2011 & 2012 \\
\hline Production program & & & & & & \\
Agricultural Practices & 0 & 0 & 0 & 22 & 93 & 5 \\
Agricultural Production & 40 & 849 & 136 & 162 & 82 & 88 \\
\hline $\begin{array}{l}\text { Environmental program } \\
\text { Water }\end{array}$ & 0 & 0 & 247 & 100 & 165 & 42 \\
Environmental Manag. & 0 & 0 & 0 & 35 & 115 & 20 \\
\hline Gender program & 0 & 0 & 4 & 78 & 56 & 21 \\
\hline Post-harvest program & 0 & 0 & 0 & 48 & 97 & 54 \\
\hline Market linkage program & & & & & & \\
Entrepreneurial practices & 30 & 217 & 99 & 66 & 133 & 71 \\
Municipality eng. & 0 & 197 & 86 & 33 & 74 & 246 \\
\hline Total \# producers & 1,128 & 3,191 & 1,539 & 1,071 & 1,541 & 1,367 \\
\hline \% participation in & $3 \%$ & $7 \%$ & $6 \%$ & $6 \%$ & $9 \%$ & $5 \%$ \\
Entrepreneurial practices & $3 \%$ & & & & & \\
\hline
\end{tabular}

Source: CRS data base modified by authors

In our estimation, we hold those who participated in "entrepreneurial practices" activities as the treatment group and the rest as the control group. We are aware that farmers in the control group are also participants of the NGO project. However, our purpose is to assess effectiveness of the market linkage program rather than the project as a whole. Therefore, identification of treatment effects is possible with appropriate estimation strategies. We will discuss the details in Section 3.3.

"Entrepreneurial practices" activities targeted to develop farmer cooperatives as credible business enterprises which provide services to the members and contribute to their livelihood improvement (CRS, 2010). Workshops and knowledge exchange activities were organized in order for individual producers to understand the importance of the roles of cooperatives. Activities covered a wide range of topics such as financial sustainability and independence, book keeping, transparency in organizational governance, providing services to members, and improving environmental sustainability. In addition, individuals participated in business meetings to build network with potential buyers. Therefore, we expect that the intervention had direct effect on commercialization unlike other activity types. The detailed list of activities in all programs is presented in Section 6.2. 


\subsection{Empirical estimation strategy}

\subsubsection{Conceptual framework}

We define all market types except local wholesale markets as linked markets. The empirical literature refers to traditional markets as "wet markets" (e.g. Schipmann \& Qaim, 2011) and markets where product exchange is rather "loose” (Assefa \& Minten, 2015). In our research context, only local wholesales markets meet such descriptions. Private companies require stricter product quality and quantity standards while intermediaries are directly linked to private companies (e.g. supermarkets). Once producers sell their products to cooperatives, they market the collected goods to buyers including private companies. Products may be processed within cooperatives before being commercialized. Therefore, sales outside local markets involve product standards, supply agreement and product differentiation. Such economic transactions which require commitments and compliance are virtually nonexistent in local wholesale markets. For these reasons, we classify linked markets as non-local markets.

Figure 3.1 illustrates the possible impact pathways of the market linkage program in increasing volume of sales to alternative markets. The market linkage program provides individuals with trainings on organizational structure and the importance of providing services to cooperative members. At the same time, it also initiates negotiation between cooperatives and local governments.

Figure 3.1. Possible impact pathway of the market linkage program

Source: Authors

As a result, cooperatives are able to provide adequate services and assist producers in product marketing. As producers benefit from improved management of cooperatives, they come to trust the organizations and sell their products to the cooperatives. Also, services provided by the 
cooperatives can help increase production quantity and quality, which encourages product marketing to other linked buyers. Therefore, it helps small producers to market their products outside the community.

Table 3.2. Number of bean producers who sold in different markets: 2006-2012

\begin{tabular}{ccccccc}
\hline & Local & \multicolumn{6}{c}{ Linked markets } \\
Year & market & Farmer org. & Intermediary & Private comp. & Total & $\%$ \\
\hline 2006 & 518 & - & - & 10 & 10 & $1.89 \%$ \\
2007 & 2,144 & - & - & 53 & 53 & $2.41 \%$ \\
2008 & 2,827 & 34 & 590 & 462 & 1,086 & $27.75 \%$ \\
2009 & 1,695 & - & - & 32 & 32 & $1.85 \%$ \\
2010 & 1,862 & - & - & 181 & 181 & $8.86 \%$ \\
2011 & 2,121 & - & - & 19 & 19 & $0.89 \%$ \\
2012 & 1,415 & - & - & - & - & $0.00 \%$ \\
\hline Total & 12,582 & 34 & 590 & 757 & 1,381 & $6.24 \%$ \\
\hline
\end{tabular}

Source: CRS data base modified by authors

Business exchange in linked markets was a small fraction of total sales activities and did not grow over the project intervention phase. Table 3.2 and Table 3.3 present the number of producers who sold beans to each type of markets and quantity of beans exchanged in linked and all markets in a given year, respectively. The first indicates that the majority of sales transactions occurred in local markets rather than in linked markets. On average, sales transactions in linked markets take up merely $6.24 \%$ of total sales. The figure in 2008 is the highest at $28 \%$ or 1,086 of total bean producers and the lowest is recorded in 2012 where no producer sold in linked markets.

Table 3.3. Quantity of bean sales (qq) to linked and local markets: 2006-2012

\begin{tabular}{cccc}
\hline Year & Total & Linked & \% Linked \\
\hline 2006 & 6,026 & 123 & $2.03 \%$ \\
2007 & 29,647 & 672 & $2.27 \%$ \\
2008 & 94,215 & 22,133 & $23.49 \%$ \\
2009 & 52,668 & 13,827 & $26.25 \%$ \\
2010 & 33,611 & 3,144 & $9.35 \%$ \\
2011 & 46,700 & 419 & $0.90 \%$ \\
2012 & 31,041 & - & $0.00 \%$ \\
\hline Total & 293,907 & 40,318 & - \\
\hline
\end{tabular}

Source: CRS data base modified by authors

Similarly, the amount of beans sold in linked markets is small also in terms of quantity. Quantities of beans sold in linked markets range between $0 \%$ and 26\% of total sales quantity between 2006 and 2012. These observations show that the fraction of economic transactions that occurred in linked markets is rather small both in terms of the number of producers and quantity exchanged. 
The economic transactions during 2008 and 2009 were more active in linked markets compared with other years. In 2008 and 2009, 24\% and 26\% of all bean producers sold at linked markets, respectively. The reason why sales activities in linked markets were less in 2010 and 2011 may be due to an informal export restriction imposed on beans during these two years (The Economist, 2011). The Nicaraguan government implemented this policy in order to protect domestic bean consumers. Therefore, bean export during these two years decreased (FAO, n.d.-a), which may explain the significant decrease in beans sold outside local markets in our sample.

\subsubsection{Data}

We utilize the same data set as in Chapter 2, which was recorded by the NGO on project participants who produce staple beans. The data set contains a total of 5,054 bean farmers and 10,194 observations $^{12}$ on bean sales. As long as an individual farmer was part of the project, the NGO reports all sales activities s/he generated during the five years. This holds true even when individuals did not participate in any activities in a given year. In addition, the data contain all individuals who participated in the project. We exploit the full unbalanced panel data set.

Our outcome variable is defined as quantity of beans sold in linked markets. We also alternate with the fraction of bean quantity sold in linked markets with respect to total sales quantity. Variables related to individual characteristics are gender, head of household, and leadership positions in a cooperative. We also use information regarding department and villages that farmers live to control for location-fixed effects.

The production-related variables are total annual production area of beans and total annual production cost of beans. Empirical literature does not have general consensus as to how production area size affects participation in modern markets (Carletto et al., 2010; Michelson, 2013; Schipmann \& Qaim, 2010). However, we expect the bigger the cultivated area, the larger the volume of sales to linked markets. It is because our study is concerned solely with sales volume to non-local markets and intuitively households with larger land areas are likely to produce and sell more products than those with smaller area. Production costs can affect volume of sales in either direction. Higher production cost may mean more sophisticated production technology and therefore higher product quality. In this case, households may sell the final products to linked markets which require certain quality of goods. If, on the contrary, higher cost means low efficiency, the products are less likely to enter non-local markets.

As all producers in the data set are the project's participants, they received interventions outside the entrepreneurial practices activities over the five years. To control for participation in different activities, we include seven dummy variables that indicate participation in the remaining activity

\footnotetext{
${ }^{12}$ This figure differs from Chapter 2. The reason is because data used in Chapter 2 excludes sales of seeds and plants, resulting in a decrease in the number of producers. However, the observations are larger in Chapter 2 since we estimate based on all sales activities while Chapter 3 looks at annual sales activities.
} 
categories. Namely, we generate dummies for agricultural practices and agricultural production (production program), water and environmental management (environmental program), gender (gender program), post-harvest management (post-harvest program), and municipality engagement (market linkage program). In addition to the binary variables, we apply the total number of training days participated in a year and cost of trainings that farmers incurred. Frequent participation may affect the sales volume positively while paying for trainings may be associated with higher commitment and therefore, faster adoption of the lessons learned in training sessions.

All program participation is treated as cumulative. For instance, if an individual received intervention in business social relationship activities during 2009, 2010 and 2012, s/he takes the value of "0" in year 2007 and 2008 and “1” in 2009, 2010, 2011 and 2012. In other words, even though this individual did not receive intervention during 2011, the cumulative value of the participation stays " 1 ". The intuition is that capacity building is concerned with individual's change in behavior and knowledge. Once an individual undertakes training, s/he is likely to remember, and therefore may apply, the knowledge obtained from the trainings years before.

Table 3.4. Comparison between market linkage program participants and non-participants

\begin{tabular}{lccc}
\hline & $\begin{array}{c}\text { Participants } \\
(1)\end{array}$ & $\begin{array}{c}\text { Non-part. } \\
(2)\end{array}$ & $\begin{array}{c}\text { Differences } \\
(1)-(2)\end{array}$ \\
\hline Characteristics variables & & & \\
Sex (= 1, if female) & 0.21 & 0.19 & 0.02 \\
Household head (= 1, if household head) & 0.52 & 0.46 & $0.06^{*}$ \\
Cooperative membership (= 1, if member) & 0.94 & 0.87 & $0.06^{* *}$ \\
Leadership (=1, if in a leadership position) & 0.65 & 0.37 & $0.28^{* * *}$ \\
& & & \\
Marketing and production variables & & & \\
Production diversification & 0.27 & 0.17 & $0.10^{* * *}$ \\
(=1, if sell other crops besides beans) & 1.50 & 1.20 & $0.30^{* * *}$ \\
Area (Ha) & 58.34 & 42.98 & $15.35^{* * *}$ \\
Total production cost (USD) & 38.53 & 27.42 & $11.11^{* * *}$ \\
Total quantity of beans sold (qq) & 32.54 & 28.73 & $3.81^{* *}$ \\
Bean yield (qq/Ha) & 3.45 & 2.55 & $0.89^{* *}$ \\
Quantity sold to linked markets (qq) & 0.10 & 0.09 & 0.01 \\
\% of beans sold to linked markets & 1,302 & 8,892 & \\
\hline Observations & & & \\
\hline * & & & \\
\hline
\end{tabular}

${ }^{*} p<0.10,{ }^{* *} p<0.05,{ }^{* * *} p<0.01$

Source: Authors' calculation

Table 3.4 summarizes basic characteristics of producers in the treatment and control groups. The descriptive statistics show that the two groups do not have statistically significant difference regarding gender distribution. 52\% of the farmers who participated in the market linkage program are household heads while the percentage drops by $6 \%$ in the control group. Less of treated farmers belong to a cooperative than untreated farmers. More producers in the treatment groups are in leadership positions in a cooperative than those in the control group. 
Program participants diversify commodity sales more than non-participants. Moreover, they have larger land areas and incur higher cost of production (\$15 per year more than non-participants). Also, both production quantity and production yield of program participants are larger than nonparticipants. Treated producers sell more to linked markets in terms of absolute quantity. The amount of beans sold to linked markets is a small fraction of total quantity sold for both groups. On average, producers in the treatment group sold 32.54qq of beans, 3.45qq of which was exchanged in linked markets. Producers in the control group sold 2.55qq in linked markets out of a total of 28.73qq on average. In other words, sales to linked markets take up merely $10.60 \%$ and $8.88 \%$ of total bean sales on average for the treatment group and control group, respectively.

\subsubsection{Econometric model}

This section discusses the identification strategy of the average treatment effect on the treated (ATT) of entrepreneurial practices. As an outcome variable, we select the quantity of beans sold in non-local markets. The estimation equation is specified as:

$y_{i}=\beta+\alpha_{i} d_{i}+u_{i}$

where $y_{i}$ is the outcome variable of individual $i, \beta$ is the intercept, $d_{i}$ is the treatment status $\left(d_{i}=1\right.$ if $i$ is treated, 0 otherwise), and $u_{i}$ is the error term. In the presence of selection bias into $d_{i}$, the ATT estimator, $\propto^{\mathrm{ATT}}$, is expressed as:

$$
\begin{aligned}
\propto^{\mathrm{ATT}} & =\mathrm{E}\left(\propto_{\mathrm{i}} \mid \mathrm{d}_{\mathrm{i}}=1\right) \\
& =\mathrm{E}\left(\propto_{\mathrm{i}} \mid \mathrm{g}\left(\mathrm{Z}_{\mathrm{i}}, \mathrm{v}_{\mathrm{i}}\right) \geq 0\right)
\end{aligned}
$$

where the selection depends on a vector of covariates, $Z_{i}$, and the error term, $v_{i}$.

We employ the difference-in-differences (DID) approach in order to estimate the ATT. First, we test if program participation is endogenous, following the Hausman test (Wooldridge, 2010) and Smith-Blundell test (Smith \& Blundell, 1986). Both test results indicate that the linkage program participation is endogenous, suggesting that the Two-Stage Least Square approaches are suitable to obtain unbiased estimates. However, we lack appropriate instrumental variables to explain the program participation decision. Based on a common trend assumption, DID assumes that the $\mathrm{u}_{\mathrm{i}}$ depends on unobservable individual-specific effects and macro shock. Therefore, there is no selection on untreated outcomes when first differences are taken (Blundell \& Dias, 2009):

$\mathrm{E}\left[\mathrm{u}_{\mathrm{it}_{1}}-\mathrm{u}_{\mathrm{it}_{10}} \mid \mathrm{d}_{\mathrm{i}}=1\right]=\left[\mathrm{u}_{\mathrm{it}_{1}}-\mathrm{u}_{\mathrm{it}_{10}} \mid \mathrm{d}_{\mathrm{i}}=0\right]=\left[\mathrm{u}_{\mathrm{it}_{1}}-\mathrm{u}_{\mathrm{it}_{10}}\right]$

Thus, under the DID assumption, the estimation equation becomes:

$$
\begin{aligned}
\mathrm{E}\left[\mathrm{y}_{\mathrm{it}} \mid \mathrm{d}_{\mathrm{i}}, \mathrm{t}\right] & =\beta+\mathrm{E}\left[\alpha_{\mathrm{i}} \mid \mathrm{d}_{\mathrm{i}}=1\right]+\mathrm{E}\left[\mathrm{n}_{\mathrm{i}} \mid \mathrm{d}_{\mathrm{i}}=1\right]+\mathrm{m}_{\mathrm{t}} \text { if } \mathrm{d}_{\mathrm{i}}=1 \text { and } \mathrm{t}=\mathrm{t}_{\mathrm{i}} \\
& =\beta+\mathrm{E}\left[\mathrm{n}_{\mathrm{i}} \mid \mathrm{d}_{\mathrm{i}}=1\right]+\mathrm{m}_{\mathrm{t}} \quad \text { otherwise. }
\end{aligned}
$$

Therefore, the estimated ATT in Equation (3.2) becomes:

$\widehat{\alpha}^{\mathrm{DID}}=\left[\overline{\mathrm{y}}_{\mathrm{t}_{1}}^{1}-\overline{\mathrm{y}}_{\mathrm{t}_{0}}^{1}\right]-\left[\overline{\mathrm{y}}_{\mathrm{t}_{1}}^{0}-\overline{\mathrm{y}}_{\mathrm{t}_{0}}^{0}\right]$

In other words, the DID estimators are the excess change in the y in the treatment group compared with that of the control group. 
Since the estimation strategy mentioned above concerns with scenarios over two distinctive periods (i.e. before and after the intervention), we modify our specification model, following Wooldridge (2010). We express the model as:

$\Delta \mathrm{y}_{\mathrm{it}}=\xi_{\mathrm{t}}+\beta_{1} \Delta \mathrm{P}_{\mathrm{it}}+\beta_{2} \mathrm{I}_{\mathrm{it}}+\delta_{1} \mathrm{~T}_{\mathrm{it}}+\Delta \mathrm{u}_{\mathrm{it}}$

$y_{i t}$, the outcome variable, is the total volume of beans that farmer i sold in year t. $\xi_{t}$ are time period intercepts to control for $\mathrm{m}_{\mathrm{t}}, \mathrm{P}_{\mathrm{it}}$ is a set of production-related variables in levels (total annual production area of beans, and total annual production cost of beans), and $\mathrm{I}_{\mathrm{it}}$ is a set of interventionrelated variables (seven dummy variables that indicate whether or not individuals participated in intervention activities outside the entrepreneurial practices activities in a given year, total number of capacity building days that farmers participated in a given year, and cost of capacity building activities that farmers themselves incurred). $\mathrm{T}_{\mathrm{it}}$ represents a binary variable, indicating individuals' entrepreneurial activity participation status in year t. Therefore, the estimator, $\delta_{1}$, captures the ATT of entrepreneurial practices participation, our main interest. $\Delta$ indicates that a difference was taken.

The DID estimators can be seriously biased upward in the existence of serial autocorrelation (SA) (Bertrand et al., 2004). We test for serial correlation, following Wooldridge (2010). The test result indicates that serial correlation exists in our data set. Therefore, we obtain unbiased estimators, following the two-step correction procedures suggested by Bertrand et al. (2004). For the details of the procedure, see Bertrand et al. (2004) and Michelson (2013).

For robustness check, we use lagged interventions variables to account for possible endogeneity. In addition, we control for geographical fixed effects by including dummy variables indicating individual departments and villages. Finally, we replace the outcome variable by the fraction of beans sold in linked markets. All results are presented in Table 3.5 and Table 3.6.

\subsection{Estimation results}

Table 3.5 presents the regression results for estimations with quantity sold in linked markets as outcome variable. All models show positive and statistically significant effect of entrepreneurial activities on the quantity sold. For instance, Column 1 indicates that those who participated in the entrepreneurial activities sold on average 2.02qq more than those who did not. Similarly, the standard SA-corrected model shows the magnitude of 2.78qq increase for participants. When geographical fixed effects are taken into account, the effect becomes 2.70qq and 2.91qq for department and village fixed effect, respectively (Columns 4 through 5). When lagged intervention variables are employed, participants of entrepreneurial practices show 4.18 qq and 6.73 qq higher sales volumes than those who did not participate (Column 2 and 6). Therefore, we can confirm that the positive and statistically significant effect of entrepreneurial activities on market linkage. 
Table 3.5. Regression results: Y = Quantity (qq) sold in linked markets (t-value in brackets)

\begin{tabular}{|c|c|c|c|c|c|c|}
\hline & \multicolumn{2}{|c|}{ Standard DID } & \multicolumn{4}{|c|}{ Serial autocorrelation corrected } \\
\hline & DID & $\begin{array}{c}\text { Interventions } \\
\text { lagged }\end{array}$ & SA corrected & $\begin{array}{l}\text { Department } \\
\text { fixed effect }\end{array}$ & $\begin{array}{c}\text { Village } \\
\text { fixed effect }\end{array}$ & $\begin{array}{c}\text { Interventions } \\
\text { lagged }\end{array}$ \\
\hline & (1) & $(2)$ & (3) & (4) & (5) & $(6)$ \\
\hline Production area & $\begin{array}{c}6.48 \\
(5.14)^{* * *}\end{array}$ & $\begin{array}{c}6.34 \\
(22.18)^{* * *}\end{array}$ & & & & \\
\hline Production cost & $\begin{array}{c}-0.00 \\
(0.06)\end{array}$ & $\begin{array}{c}0.00 \\
(0.03)\end{array}$ & & & & \\
\hline $\begin{array}{l}\text { Entrepreneurial } \\
\text { practices }\end{array}$ & $\begin{array}{c}2.02 \\
(2.13)^{* *}\end{array}$ & $\begin{array}{c}4.18 \\
(3.55)^{* * *}\end{array}$ & $\begin{array}{c}2.78 \\
(5.94)^{* * *}\end{array}$ & $\begin{array}{c}2.70 \\
(5.81)^{* * *}\end{array}$ & $\begin{array}{c}2.91 \\
(6.30)^{* * *}\end{array}$ & $\begin{array}{c}6.73 \\
(7.88)^{* * *}\end{array}$ \\
\hline $\begin{array}{l}\text { Municipality } \\
\text { training }\end{array}$ & $\begin{array}{c}-1.69 \\
(2.32)^{* *}\end{array}$ & $\begin{array}{l}-0.89 \\
(0.66)\end{array}$ & $\begin{array}{c}-2.81 \\
(6.03)^{* * *}\end{array}$ & $\begin{array}{c}-3.18 \\
(6.81)^{* * *}\end{array}$ & $\begin{array}{c}-3.30 \\
(6.92)^{* * *}\end{array}$ & $\begin{array}{c}-2.20 \\
(2.24)^{* *}\end{array}$ \\
\hline $\begin{array}{l}\text { Agricultural } \\
\text { practices }\end{array}$ & $\begin{array}{c}2.33 \\
(1.54)\end{array}$ & $\begin{array}{c}4.91 \\
(1.44)\end{array}$ & $\begin{array}{l}-0.12 \\
(0.10)\end{array}$ & $\begin{array}{l}-0.35 \\
(0.31)\end{array}$ & $\begin{array}{c}0.01 \\
(0.01)\end{array}$ & $\begin{array}{c}0.32 \\
(0.13)\end{array}$ \\
\hline $\begin{array}{l}\text { Agricultural } \\
\text { production }\end{array}$ & $\begin{array}{c}-1.98 \\
(3.18)^{* * *}\end{array}$ & $\begin{array}{c}-5.64 \\
(6.04)^{* * *}\end{array}$ & $\begin{array}{l}-0.39 \\
(1.12)\end{array}$ & $\begin{array}{l}-0.25 \\
(0.71)\end{array}$ & $\begin{array}{c}-0.58 \\
(1.67)^{*}\end{array}$ & $\begin{array}{c}-2.25 \\
(3.41)^{* * *}\end{array}$ \\
\hline Water & $\begin{array}{c}-0.28 \\
(0.32)\end{array}$ & $\begin{array}{c}-5.07 \\
(3.97)^{* * *}\end{array}$ & $\begin{array}{l}-0.67 \\
(1.34)\end{array}$ & $\begin{array}{l}-0.50 \\
(1.01)\end{array}$ & $\begin{array}{c}-0.04 \\
(0.09)\end{array}$ & $\begin{array}{c}-1.75 \\
(1.92)^{*}\end{array}$ \\
\hline Environmental & -0.10 & 5.50 & 0.22 & -0.18 & -2.02 & 0.06 \\
\hline management & $(0.09)$ & $(2.37)^{* *}$ & $(0.24)$ & $(0.20)$ & $(2.28)^{* *}$ & $(0.04)$ \\
\hline Gender & $\begin{array}{l}-3.33 \\
(1.40)\end{array}$ & $\begin{array}{c}2.24 \\
(0.90)\end{array}$ & $\begin{array}{c}-3.71 \\
(3.89)^{* * *}\end{array}$ & $\begin{array}{c}-3.52 \\
(3.70)^{* * *}\end{array}$ & $\begin{array}{c}-1.66 \\
(1.76)^{*}\end{array}$ & $\begin{array}{l}-1.61 \\
(0.89)\end{array}$ \\
\hline $\begin{array}{l}\text { Post-harvest } \\
\text { program }\end{array}$ & $\begin{array}{l}-0.25 \\
(0.14)\end{array}$ & $\begin{array}{c}2.86 \\
(1.02)\end{array}$ & $\begin{array}{l}-1.16 \\
(1.28)\end{array}$ & $\begin{array}{c}-0.74 \\
(0.82)\end{array}$ & $\begin{array}{l}-1.16 \\
(1.30)\end{array}$ & $\begin{array}{l}-1.09 \\
(0.53)\end{array}$ \\
\hline Days & 0.39 & -0.10 & 1.35 & 1.15 & 1.12 & -0.32 \\
\hline participated & $(1.74)^{*}$ & $(0.34)$ & $(7.46)^{* * *}$ & $(6.37)^{* * *}$ & $(6.30)^{* * *}$ & $(1.52)$ \\
\hline Cost for farmers & $\begin{array}{c}-0.03 \\
(2.21)^{* *}\end{array}$ & $\begin{array}{l}-0.02 \\
(0.96)\end{array}$ & $\begin{array}{c}-0.06 \\
(4.29)^{* * *}\end{array}$ & $\begin{array}{c}-0.06 \\
(4.11)^{* * *}\end{array}$ & $\begin{array}{c}-0.05 \\
(3.88)^{* * *}\end{array}$ & $\begin{array}{c}0.04 \\
(2.32)^{* *}\end{array}$ \\
\hline$R^{2}$ & 0.21 & 0.22 & 0.01 & 0.04 & 0.09 & 0.02 \\
\hline$N$ & 5,149 & 5,149 & 10,194 & 10,194 & 10,194 & 5,149 \\
\hline
\end{tabular}

Source: Authors' calculation 
Another robust and positive results are the total number of days participated. Standard SA-corrected model shows that an additional day participated is associated with an increase in sales volume by 1.35 qq on average (Column 3). Similarly, an additional day participated would increase the sales quantity in dynamic markets by 1.15 qq and 1.12 qq with department and village fixed effects, respectively (Column 4 through 5).

When the DID estimators are corrected to account for serial autocorrelation, production variables and basic characteristic indicators are not included in the second-stage estimation. That is why the standard DID models present production variables while the SA-corrected models do not. The reason why the elicited $\mathrm{R}^{2}$ values are low is also due to the two-stage estimation procedure. Therefore, the standard DID models explain larger variation of the observations than in SAcorrected models.

Table 3.6 presents results with fraction of quantity sold in linked markets with respect to total bean quantity sold in any market as an outcome variable. The results are similar to those in Table 3.5 in terms of the direction of effect. Standard DID model shows that entrepreneurial practices participants sold 0.2 percentage points more beans to dynamic markets than non-participants (Column 1). Likewise, SA-corrected model indicates that the difference is 0.5 percentage points.

Positive influence of general participation is also confirmed. All estimation results except in those with lagged intervention variables show positive correlation between total number of days participated and percentage of beans sold in linked markets. An additional day of capacity building participated is associated with a 0.4 percentage point increase on average when estimated in a SAcorrected DID model (Column 3). With geographical fixed effects, the effect becomes 0.3 percentage point increase (Column 4 and 5).

In all estimations, we cannot find robust, positive and statistically significant effect of any other intervention activities. This may indicate that classical extension services concerning agricultural productivity increase do not have effects on market linkage. Put in another way, facilitating smallholder commercialization requires a distinct set of intervention activities in addition to activities related to productivity increase.

\subsection{Discussion}

In order to map an impact pathway, we estimate how increase in bean sales in dynamic markets affects sales income, controlling for intervention activities undertaken by individual producers. The result is presented in Table 3.7. We show solely the SA-corrected estimators since the DID estimators show similar trends as to the presented results.

All estimation models indicate that the higher the percentage of beans sold in dynamic markets, the 
Table 3.6. Regression results: $\mathrm{Y}$ = Fraction (\%) of quantity sold in linked markets (t-value in brackets)

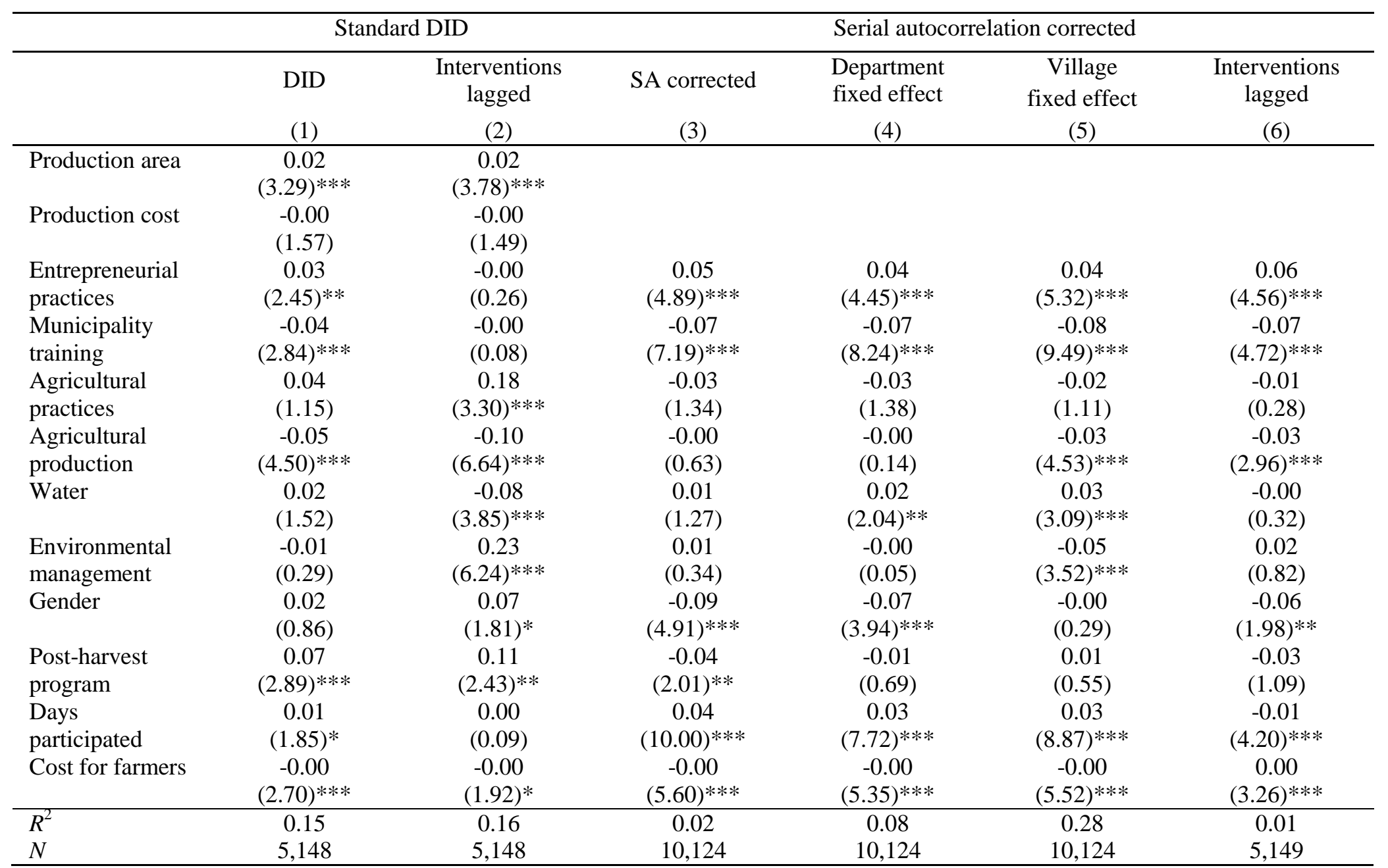

$* p<0.1 ; * * p<0.05 ; * * * p<0.01$

Source: Authors' calculation 
higher sales income is. More specifically, a percentage point increase in bean sales to linked markets is associated with an increase in total sales income by 0.30 USD (Column 1). With department and village-level fixed effects, the effect is approximately 0.50 USD (Column 2 and 3). Such findings confirm that increased engagement in commercialization has positive effect on increasing welfare. This is consistent with findings in the empirical literature. Therefore, we can confirm that entrepreneurial practices assist alleviation of poverty through facilitating commercialization by smallholders.

Table 3.7. Regression results: $\mathrm{Y}=$ total bean sales income (USD) (t-value in brackets)

\begin{tabular}{|c|c|c|c|c|}
\hline & SA corrected & $\begin{array}{c}\text { Department } \\
\text { fixed effect } \\
\text { (2) }\end{array}$ & $\begin{array}{c}\text { Village } \\
\text { fixed effect } \\
\text { (3) }\end{array}$ & $\begin{array}{c}\text { Interventions } \\
\text { lagged } \\
(4)\end{array}$ \\
\hline$\%$ bean sales to & 0.30 & 0.50 & 0.51 & 0.32 \\
\hline linked markets & $(6.36) * * *$ & $(10.22)^{* * *}$ & $(10.19)^{* * *}$ & $(6.84) * * *$ \\
\hline $\begin{array}{l}\text { Entrepreneurial } \\
\text { practices }\end{array}$ & $\begin{array}{c}0.09 \\
(2.55)^{* *}\end{array}$ & $\begin{array}{c}0.12 \\
(3.54)^{* * *}\end{array}$ & $\begin{array}{c}0.06 \\
(1.75)^{*}\end{array}$ & $\begin{array}{c}0.17 \\
(3.53)^{* * *}\end{array}$ \\
\hline $\begin{array}{l}\text { Municipality } \\
\text { training }\end{array}$ & $\begin{array}{c}-0.06 \\
(1.88)^{*}\end{array}$ & $\begin{array}{c}0.00 \\
(0.12)\end{array}$ & $\begin{array}{l}-0.00 \\
(0.09)\end{array}$ & $\begin{array}{c}-0.13 \\
(2.49)^{* *}\end{array}$ \\
\hline $\begin{array}{l}\text { Agricultural } \\
\text { practices }\end{array}$ & $\begin{array}{c}0.08 \\
(0.98)\end{array}$ & $\begin{array}{c}0.14 \\
(1.73)^{*}\end{array}$ & $\begin{array}{c}0.19 \\
(2.34)^{* *}\end{array}$ & $\begin{array}{c}0.24 \\
(1.68)^{*}\end{array}$ \\
\hline $\begin{array}{l}\text { Agricultural } \\
\text { production }\end{array}$ & $\begin{array}{c}-0.05 \\
(1.71)^{*}\end{array}$ & $\begin{array}{c}0.00 \\
(0.10)\end{array}$ & $\begin{array}{c}0.03 \\
(1.24)\end{array}$ & $\begin{array}{c}-0.21 \\
(6.30)^{* * *}\end{array}$ \\
\hline Water & $\begin{array}{c}0.14 \\
(3.92)^{* * *}\end{array}$ & $\begin{array}{c}0.11 \\
(3.16)^{* * *}\end{array}$ & $\begin{array}{c}0.09 \\
(2.39)^{* *}\end{array}$ & $\begin{array}{c}0.09 \\
(1.84)^{*}\end{array}$ \\
\hline $\begin{array}{l}\text { Environmental } \\
\text { management }\end{array}$ & $\begin{array}{c}-0.08 \\
(1.37)\end{array}$ & $\begin{array}{c}0.01 \\
(0.16)\end{array}$ & $\begin{array}{c}0.08 \\
(1.40)\end{array}$ & $\begin{array}{c}-0.06 \\
(0.68)\end{array}$ \\
\hline Gender & $\begin{array}{c}0.16 \\
(2.35)^{* *}\end{array}$ & $\begin{array}{c}0.20 \\
(2.91)^{* * *}\end{array}$ & $\begin{array}{c}0.10 \\
(1.53)\end{array}$ & $\begin{array}{c}0.12 \\
(1.14)\end{array}$ \\
\hline $\begin{array}{l}\text { Post-harvest } \\
\text { program }\end{array}$ & $\begin{array}{l}-0.05 \\
(0.72)\end{array}$ & $\begin{array}{l}-0.04 \\
(0.53)\end{array}$ & $\begin{array}{c}0.05 \\
(0.73)\end{array}$ & $\begin{array}{l}-0.12 \\
(1.03)\end{array}$ \\
\hline Days & 0.01 & 0.00 & 0.00 & 0.01 \\
\hline $\begin{array}{l}\text { participated } \\
\text { Cost for }\end{array}$ & $\begin{array}{l}(0.53) \\
-0.00\end{array}$ & $\begin{array}{c}(0.24) \\
0.00\end{array}$ & $\begin{array}{c}(0.15) \\
0.00\end{array}$ & $\begin{array}{c}(0.44) \\
0.00 \\
(0.24)\end{array}$ \\
\hline$\frac{\text { farmers }}{R^{2}}$ & $(0.45)$ & $(0.25)$ & $(0.11)$ & $(0.24)$ \\
\hline $\begin{array}{l}R^{2} \\
N\end{array}$ & $\begin{array}{c}0.02 \\
5,148\end{array}$ & $\begin{array}{c}0.08 \\
5,148\end{array}$ & $\begin{array}{c}0.12 \\
5,148\end{array}$ & $\begin{array}{c}0.02 \\
5,148\end{array}$ \\
\hline
\end{tabular}

Source: Author's calculation

It is also noteworthy that traditional intervention activities such as agricultural practices and waterrelated activities show positive correlation with sales income. Our findings confirm the positive link between farm extension services and market linkage that research suggests (e.g. Bignebat \& Vagneron, 2011; Carletto et al., 2011; Kersting \& Wollni, 2012; Subervie \& Vagneron, 2013). While such traditional intervention activities do not show positive effect on commercialization, they play important role in contributing to household income, and therefore reduction of poverty. 


\subsection{Conclusions}

Commercialization of agricultural commodities has been seen essential for economic development and alleviation of poverty. Recognizing the importance and potential of market linkage, a number of development agencies are launching on projects that focus on smallholder commercialization. However, empirical research to date lacks evidences to show whether such projects have effect on commercialization and by how much. Corresponding to such shortcomings, our research scrutinizes one NGO-based project in order to understand impact pathways how donor-funded interventions can influence smallholder commercialization. As a case study, we select an NGO-project undertaken in rural Nicaragua between 2007 and 2012. We conduct our analysis on staple bean farmers.

Using an unbalanced panel data set recorded by the NGO, we test whether training farmers regarding entrepreneurial practices has positive effect on commercialization outside local wholesales markets. In our analysis, we define linked markets as sales directed to farmer cooperatives, intermediaries and private companies. We measure commercialization with absolute quantity and share of beans sold in linked markets. In order to draw causal links, we employ the difference-in-differences approach and account for unobserved heterogeneity. The DID estimators suffer from serial autocorrelation. Thus, we solve this problem by applying a two-stage estimation procedure suggested by Bertrand et al. (2004).

The results indicate that activities regarding entrepreneurial practices have positive and statistically significant effect on commercialization. We also find that increased commercialization is positively correlated with total bean sales income, suggesting a positive indirect effect of the activities. Other activities demonstrate no positive and robust effect on commercialization while direct positive effects on sales income can be observed. This implies that market linkage of smallholder farmers require different sets of intervention tools than traditional farm technical assistance.

We recognize limitations in our study. There is no information available outside project participants in our data set. While the DID approach eliminates unobserved heterogeneity, future studies must account for selection bias into intervention activities by applying different estimation methods (e.g. instrumental variables approach, matching). Another untouched aspect is sustainability of donor-funded effort to link small farmers to commercial markets. While effect of donor-based interventions are not always maintained by smallholders (Holzapfel \& Wollni, 2014), we are not able to test long-term effects of market linkage-related projects. Studies in the future may address this question by further developing longitudinal data which include information after the duration of projects. 


\section{Intensive and Extensive Margins of NGO Interventions ${ }^{13}$}

\subsection{Introduction}

The empirical literature to date shows that product commercialization by poor producers is a necessary step in order to alleviate rural poverty in the developing world (Barrett et al., 2010; Collier \& Dercon, 2014; Dethier \& Effenberger, 2012). Particularly in the recent years, the potential of modern market channels has received considerable attention as a catalyst against poverty. While retail companies select individuals with specific endowments (Boselie et al., 2003; Dolan \& Humphrey, 2000; Farina \& Reardon, 2000; Michelson et al., 2012; Reardon et al., 2003), participation in integrated supply chains can be beneficial for small agricultural producers (Gulati et al., 2007; Markelova et al., 2009; Michelson, 2013; Minten et al., 2009; Nagaraj et al., 2008; Vieira, 2008).

However, commercialization by small agricultural producers is often hindered by a number of factors that increase transaction costs. In many of the developing economies, poor producers lack appropriate infrastructure that enables participation in commercial markets. When marketing transaction cost is high, farming households do not gain from product specialization or trade (de Janvry et al., 1991; Omamo, 1998a). As a result, only a small fraction of farmers in rural areas manage to participate in commercialization while others remain in the semi-subsistence system (Barrett et al., 2012). Generally speaking, such semi-subsistence production system is characterized with low productivity, and little to no update of production technology (Balat et al., 2009; Barrett et al., 2012; Bellemare \& Barrett, 2006; Fay \& Morrison, 2007; Goetz, 1992). As a result, the majority of small producers in developing countries are kept in the poverty trap (Barrett \& Swallow, 2006).

Heterogeneity among agricultural producers is considered as key to understanding the commercialization mechanisms. The ability to adopt improved production and processing technology is one of the most important factors that enable small agricultural producers to participate in integrated markets (Gulati et al., 2007; Narayanan \& Gulati, 2002). Another important factor is access to irrigation where farmers participating in supermarket supply chains are found to be equipped with irrigation more than non-participants (Berdegué et al., 2005; Hernández et al., 2007; Michelson, 2013; Neven et al., 2009). Geographic location and access to improved transportation infrastructure also enable small farmers to be integrated in global supply chains (Michelson, 2013; Neven et al., 2009). Examples of vertically integrated supply chains show that such production and marketing assets are provided to suppliers by retail companies (Reardon et al., 2009; Swinnen, 2007), implying the importance of these assets. As effort to link smallholders to commercial markets involves multiple levels of policy interventions (Barrett, 2008; Barrett \&

\footnotetext{
${ }^{13}$ This essay is a joint work with Manuel Hernandez at the International Food Policy Research Institute (IFPRI) in Washington, D.C.
} 
Swallow, 2006), leaving the decisions solely in private companies' hands may result in further marginalization of the poor (Jaffee et al., 2011; Whitfield, 2012).

In this context, interventions through development organizations are considered as an effective tool for policy makers to assist smallholder market participation. Development agencies- and NGObased interventions can benefit small agricultural producers by providing services necessary for commercialization (e.g. production technology upgrade, stakeholder communication, provision of inputs and credit, access to market information, and value chain development) (Humphrey, 2009; Carletto et al., 2011; Dethier \& Effenberger, 2012; Whitfield, 2012; Kersting \& Wollni, 2012). In fact, a number of donor agencies (e.g. USAID, DFID, GIZ, FAO, and IFAD) have launched projects to develop integrated supply chains that include smallholder farmers (Bignebat \& Vagneron, 2011; FAO, n.d.; Humphrey, 2009; IFAD, 2012; Stoian et al., 2012). However, the attempt to link smallholders to commercial markets undertaken by development projects is relatively new (Jaffee et al., 2011), thereby lacking empirical evidences on their effectiveness and success (Barrett, 2008; Humphrey \& Navas-Alemán, 2010; Mithofer, 2011; Stoian et al., 2012).

While the previous chapter of the thesis addresses this shortcoming explicitly, this chapter extends the analysis to shed light on heterogeneity among small producers when reflecting NGO-based intervention activities onto commercial marketing. The literature shows that differences in terms of individual and production characteristics are crucial in commercial marketing. Thus, we investigate whether NGO-based capacity building activities affect producers who entered commercial markets after the interventions differently than those who had already participated in such markets prior to the interventions.

More specifically, our paper tests two hypotheses: 1. external support has positive effect on commercialization at the extensive and intensive margins and 2. the effect is different for entrant farmers than those already in commercial markets prior to the NGO interventions.

We apply the identical data set of staple bean farmers in Nicaragua as in the previous chapters of the thesis. Staple grains provide less inventive for smallholder farmers to commercialize than highvalue fresh vegetables and fruits. This is because there is little product differentiation that fetches increased producer prices (Berdegué, 2002; Hellin et al., 2009). However, staple grain commercialization is necessary in order to facilitate shifts away from semi-subsistence system to more market-based production of high value commodities (Barrett, 2008). Therefore, our analysis continues to focus on staple bean producers.

The rest of the chapter is organized as follows. Section 4.2 explains the empirical estimation strategy by presenting the conceptual framework, data, and the econometric model. In Section 4.3, we show the econometric results at the intensive and extensive margins. Section 4.4 discusses the empirical findings in the context of policy implementation. Finally, Section 4.5 summarizes and concludes. 


\subsection{Empirical estimation strategy}

\subsubsection{Conceptual framework}

This section outlines the theoretical foundation in estimating effects of individual activity participation on commercialization in linked markets at the intensive and extensive margins. Linked markets in our study refer to all but local wholesale markets. This is because we focus on commercialization outside wet markets or traditional markets. In the context of Nicaraguan bean sales, only local markets are characterized with little to no quality requirements, immediate payment, and little long-term seller-buyer relationship. Therefore, we classify all but local wholesale markets in our data set as "linked market".

We borrow the concept of intensive and extensive margins from the trade literature. In the context of international trade, intensive margins refer to the change in the size of exchange (e.g. quantity of commodities exchanged) while extensive margins refer to participation in the international market itself (e.g. market entry or exit) (Besedeš \& Prusa, 2011; Chaney, 2008; Felbermayr \& Kohler, 2006; Li et al., 2012). Building up on the margins discussed in the trade literature, we assess whether undertaking NGO activities had distinct effects at the intensive and extensive margins.

In our context, the identification of extensive margin is expressed as follows:

$\mathrm{P}\left(\mathrm{S}_{\mathrm{it}}=1 \mid \mathrm{S}_{\mathrm{it}-1}=1\right)=\mathrm{f}(\mathrm{X}, \varepsilon)$

$\mathrm{P}\left(\mathrm{S}_{\mathrm{it}}=1 \mid \mathrm{S}_{\mathrm{it}-1}=0\right)=\mathrm{f}(\mathrm{X}, \varepsilon)$

where $\mathrm{P}$ is the probability, $\mathrm{S}_{\text {it }}$ denotes sales in linked markets by producer $\mathrm{i}$ in year $\mathrm{t}, \mathrm{X}$ is a vector of covariates that explain the probability of linked market commercialization, and $\varepsilon$ is the error term. Equation (4.1) shows the case where producer i had commercialized in linked markets in the previous year continued sales in these markets. On the contrary, Equation (4.2) explains the probability of producers entering the linked markets given that they did not sell in linked markets in the previous year.

For the identification of influence of NGO program participation at the intensive margin, the general specification is:

$\mathrm{Y}_{\mathrm{it}}=\mathrm{g}(\mathrm{Z}, \mathrm{u})$

where $Y_{i t}$ is the volume of beans sold in linked markets by producer $i$ at time $t, Z$ is a vector of covariates that explains $\mathrm{Y}_{\mathrm{it}}$ and $\mathrm{u}$ is the error term. $\mathrm{X}$ and $\mathrm{Z}$ are not necessarily identical.

In order to identify the effect of the market linkage program, first we divide the bean producers in our sample in two groups: those who sold beans outside local markets and those who did not in 2006 and/or 2007. Interviews with CRS staffs reveal that the interventions at the household level commenced only in late 2007 or early 2008. Therefore, we categorize those who had already commercialized beans in linked markets prior to 2008 as "early linkage producers" and the rest as "late linkage producers". In the following sections, we refer to the former as Group 1 and the latter as Group 2. 
The descriptive statistics in Table 4.1 show that the two groups of producers differ statistically significantly in basic, marketing and production characteristics. Among those who commercialized outside local market in 2006 and/or 2007, there are less female farmers compared with the group that did not. $46 \%$ of farmers who did not sell outside traditional markets are household heads while only $26 \%$ of those who did are. There is no statistically significant difference regarding cooperative membership. 39\% of those who did not sell to non-local markets during the first two years are in leading positions of a cooperative contrary to the other group where no farmer is in leading positions.

Table 4.1. Comparison between market linkage program participants and non-participants

\begin{tabular}{lccc}
\hline & $\begin{array}{c}\text { Sold in } \\
\text { '06-07 } \\
\text { (Group 1) }\end{array}$ & $\begin{array}{c}\text { Not sold in } \\
\text { 06-07 } \\
\text { (Group 2) }\end{array}$ & $\begin{array}{c}\text { Differences } \\
\text { (Group 2 - } \\
\text { Group 1) }\end{array}$ \\
\hline Characteristics variables & & & \\
Sex (= 1, if female) & 0.04 & 0.20 & $0.15^{* *}$ \\
Household head (= 1, if household head) & 0.26 & 0.46 & $0.20^{* *}$ \\
Cooperative membership (= 1, if member) & 0.87 & 0.88 & 0.01 \\
Leadership (=1, if in a leadership position) & 0.00 & 0.39 & $0.39^{* * *}$ \\
& & & \\
Marketing and production variables & & & \\
Commercial diversification & 0.24 & 0.19 & $-0.06^{*}$ \\
(=1, if sell other crops besides beans) & 1.12 & 1.24 & 0.12 \\
Area (Ha) & 46.29 & 45.07 & -1.22 \\
Total production cost (USD) & 31.8 & 28.76 & -3.03 \\
Total quantity of beans sold (qq) & 42.56 & 29.01 & $-13.55^{* * *}$ \\
Bean yield (qq/Ha) & 233 & 9,960 & \\
\hline Observations $\quad 35(15 \%)$ & $1,162(12 \%)$ & \\
$\quad$ Participated in the Market Linkage program & $16(7 \%)$ & $597(6 \%)$ & \\
$\quad$ Entrepreneurial practices & $20(9 \%)$ & $615(6 \%)$ & \\
\hline Municipality engagement & &
\end{tabular}

${ }^{*} p<0.10,{ }^{* *} p<0.05,{ }^{* * *} p<0.01$

Source: Authors' calculation

In terms of marketing- and production-related variables, two groups demonstrate statistically significant differences solely in terms of commercial diversification and bean yield. Producers in Group 2 on average sell other commodities besides beans less often than those in Group 1. Moreover, bean yield of producers in Group 1 is statistically significantly higher than those in Group 2. The difference is large (14qq/ha), considering that the national average of bean yield was approximately 15qq/ha between 2006 and 2012 (FAO, n.d.-a). While farmers in both groups are productive, these observations suggest that farmers in Group 2 show disadvantages regarding production of beans. This also indicates that project participants demonstrate higher productivity than the national average. 
In total, we have 9,960 observations of those who were initially not linked to non-local markets and 233 observations for those who were. For Group 1 and Group 2, 35 out of 233 and 1,162 out of 9,960 observations are treated with activities in the market linkage program, respectively. These figures are approximately $15 \%$ and $12 \%$ of the total number of producers in both groups. In terms of individual activities, 7\% and 6\% of the observations in Group 1 and Group 2 received activities regarding entrepreneurial practices, respectively. Similarly, municipality engagement activities were undertaken in 9\% and 6\% of the total observations in Group 1 and Group 2, respectively. We test whether participation in the market linkage program assisted those in Group 2 when initiating commercialization in linked markets more than those in Group 1.

\subsubsection{Data}

We utilize the same data set as in the previous chapter, which contains a total of 5,054 bean farmers and 10,193 observations on bean sales. CRS field extension staffs recorded all information throughout the project intervention period. The maximum recall period of sales information is three months, approximately one production cycle of beans. Regardless of participation in capacity building activities, CRS recorded all information. Records for all producers in the project are available as no sampling strategy was applied. We exploit the full unbalanced panel data set.

At the intensive margin, the outcome variable is defined as quantity of beans sold in linked markets (i.e. cooperatives, intermediaries, and private companies). At the extensive margin, we replace the outcome variable with a dummy variable with 1 if individuals sold beans to linked markets and 0 otherwise.

Variables related to individual characteristics are gender, head of household, and leadership positions in a cooperative. The production-related variables are total annual production area of beans and total annual production cost of beans. Instead of using the production variables in levels, we replace with the same variables observed in the previous sales activity. Lagged variables are used since production variables may generate reverse causality. While larger production area may mean that producers have surplus to sell to linked markets, producers may utilize a large piece of land as a result of commercialization. Therefore, we avoid the endogeneity problem by replacing production variables with their lagged values in all estimations.

We have information regarding who received what intervention activities throughout the five years. We generate cumulative dummy variables to control for participation in eight activity categories: 1 . agricultural practices and 2. agricultural production (production program), 3. water and 4. environmental management (environmental program), 5. gender (gender program), 6. post-harvest management (post-harvest program), 7. entrepreneurial practices and 8. municipality engagement (market linkage program). Our main interest lies in dummy variables seven and eight, the market linkage program. As in Chapter 3, individuals are noted as " 1 ” once they received interventions and " 0 " in the years before. In other words, individuals are considered as "treated" even if they did not 
receive the particular interventions in a specific given year. This is because capacity buildings are concerned with disseminating knowledge and experiences, thus having long-term effect than shorttime effect.

In addition to the dummy variables, we apply variables capturing how many days of capacity buildings individuals participated and how much producers incurred to receive activities in a given year. The first variable intends to assess whether receiving many activities has positive influence on the outcome while the second is a proxy for willingness to participate in individual activities.

\subsubsection{Econometric model}

This section discusses the identification strategy of the effect of the market linkage program participation at the intensive and extensive margins. In doing so, we deal with two specification problems: endogeneity in explanatory variables concerning participation in NGO programs, and unobserved effect, $\mathrm{c}_{\mathrm{i}}$. In general, it is argued that strict exogeneity assumption such that:

$\mathrm{c}_{\mathrm{i}} \mid \mathrm{x}_{\mathrm{i}} \sim \operatorname{Normal}\left(0, \sigma_{\mathrm{c}}^{2}\right)$

is rarely achieved (Wooldridge, 2010). For our data set, both Hausman test (Wooldridge, 2010) and Smith-Blundell test (Smith \& Blundell, 1986) fail to reject that participation is endogenous. To overcome such problems in assessing the effect of project interventions at both intensive and extensive margins, we apply various econometric methods to cope with the problems in the data set.

For the extensive margin, we employ three specification models. First is a panel probit model expressed as:

$\mathrm{P}\left(\mathrm{S}_{\mathrm{it}}=1\right)=\phi\left(\alpha_{1} \mathrm{P}_{\mathrm{it}}+\alpha_{2} \mathrm{I}_{\mathrm{it}}+\sum_{\mathrm{j}=1}^{7} \mathrm{t}_{\mathrm{j}}+\varepsilon_{\mathrm{it}}\right)$

$\mathrm{P}\left(\mathrm{S}_{\mathrm{it}}=1 \mid \mathrm{S}_{\mathrm{it}=2006,2007}=1\right)=\phi\left(\alpha_{1} \mathrm{P}_{\mathrm{it}}+\alpha_{2} \mathrm{I}_{\mathrm{it}}+\sum_{\mathrm{j}=1}^{7} \mathrm{t}_{\mathrm{j}}+\varepsilon_{\mathrm{it}}\right)$ for Group 1

$\mathrm{P}\left(\mathrm{S}_{\mathrm{it}}=1 \mid \mathrm{S}_{\mathrm{it}=2006,2007}=0\right)=\phi\left(\alpha_{1} \mathrm{P}_{\mathrm{it}}+\alpha_{2} \mathrm{I}_{\mathrm{it}}+\sum_{\mathrm{j}=1}^{7} \mathrm{t}_{\mathrm{j}}+\varepsilon_{\mathrm{it}}\right)$ for Group 2

where $\mathrm{P}_{\mathrm{it}}$ are lagged production variables (production area and cost) of producer $\mathrm{i}$ at time $\mathrm{t}, \mathrm{I}_{\mathrm{it}}$ are eight binary variables that capture participation in NGO activities, total number of activities days participated by each producer in a given year, and cost of activities that producers incurred in a given year and $t_{j}$ 's are time dummies for 2006 through 2012. $\phi$ denotes cumulative distribution functions. Equation (4.5) measures the probability of existing in non-local markets. Equation (4.6) applies for farmers in Group 1, thus probability of continuing to supply in linked markets. Equation (4.7) is for producers in Group 2, or probability to enter linked markets.

The probit estimation method for panel data set does not allow us to control for unobserved heterogeneity (Wooldridge, 2010). However, the likelihood ratio test indicates that the panel probit estimators may be biased due to individual-specific effects. Therefore, we employ the linear probability model (LPM) while using within transformation and first differencing. While LPM estimators can pose problems (e.g. estimated probability can be larger than one or smaller than zero), they can be used to check the credibility of coefficients estimated by nonlinear binary 
outcome models (Wooldridge, 2010). In summary, we apply 1. panel probit model, 2. LPM with within-transformation, and 3. LPM with first differences.

For intensive margins, we estimate the following difference-in-differences (DID) model:

$\Delta \mathrm{y}_{\mathrm{it}}=\xi_{\mathrm{t}}+\beta_{1} \Delta \mathrm{P}_{\mathrm{it}}+\beta_{2} \mathrm{I}_{\mathrm{it}}+\Delta \mathrm{u}_{\mathrm{it}}$

where $\xi_{\mathrm{t}}$ are time period intercepts to control for macro-level shocks specific to a given year and $\Delta$ denotes a change in indicated variables. As DID estimators assume parallel trend for all individuals, we can elicit average treatment effects on treated (ATT).

The DID estimators are criticized to be biased due to serial autocorrelation, which results in upward bias (Bertrand et al., 2004). We applied a diagnostic test suggested by Wooldridge (2010) and find that serial autocorrelation indeed exists in our data. Therefore, we report the corrected DID estimators, following Bertrand et al. (2004) and Michelson (2013).

The correction procedure involves two steps. First, the outcome variable is regressed on time fixed effect, village fixed effect, individual characteristics (gender, household head, cooperative leadership) and production variables (lagged area and cost of production). Then, we calculate the residuals from the first stage and further divide it into observations before and after individuals participated in NGO programs. For more details of the correction procedures, see Bertrand et al. (2004) and Michelson (2013).

\subsection{Estimation results}

First, we present the regression results at the extensive margin in Table 4.2. All presented results are marginal effects. The two LPMs and panel probit model yield different results in terms of magnitude of marginal effects, statistical significance and/or signs of estimated coefficients. This may indicate that taking individual heterogeneity into account is important for the analysis. Therefore, we interpret mainly the results of the two LPMs.

The activities in entrepreneurial practices are positively and statistically significantly correlated with the outcome variable for all producers and those in Group 2 but not Group 1. Both LPM results show that individuals in Group 2 who participated in entrepreneurial practices activities are 2-3 percentage points more likely to sell in non-local markets (columns 6 and 9) while the magnitude of the effect goes up to 39 and 34 percentage points for all and Group 2 producers in the panel probit estimation (Column 1 and 3), respectively. All estimation models indicate that the intervention had positive effects only on those who did not participate in commercial marketing outside local markets prior to the intervention phase. This is ideal since the objective of the program was to link those who were not part of commercialization in linked markets prior to project implementation. Municipality engagement activities, the other activity category of the market linkage program, do not have any statistically significant effect in all estimation models. 
4. Intensive and Extensive Margins of NGO Interventions

Table 4.2. Regression results: extensive margin (t-values in brackets)

\begin{tabular}{|c|c|c|c|c|c|c|c|c|c|}
\hline & \multicolumn{3}{|c|}{ Panel probit } & \multicolumn{3}{|c|}{ Fixed effect LPM } & \multicolumn{3}{|c|}{ LPM with first-differences } \\
\hline & $\begin{array}{l}\text { Total } \\
(1)\end{array}$ & $\begin{array}{l}\text { Group } 1 \\
(2) \\
\end{array}$ & $\begin{array}{l}\text { Group } 2 \\
(3) \\
\end{array}$ & $\begin{array}{l}\text { Total } \\
(4)\end{array}$ & $\begin{array}{l}\text { Group } 1 \\
(5) \\
\end{array}$ & $\begin{array}{c}\text { Group } 2 \\
(6) \\
\end{array}$ & $\begin{array}{c}\text { Total } \\
(7) \\
\end{array}$ & $\begin{array}{l}\text { Group } 1 \\
(8) \\
\end{array}$ & $\begin{array}{c}\text { Group } 2 \\
(9) \\
\end{array}$ \\
\hline Entrepreneurial & 0.39 & 1.71 & 0.34 & 0.03 & 0.12 & 0.03 & 0.02 & 0.04 & 0.02 \\
\hline practices & $(2.83)^{* * *}$ & $(0.56)$ & $(2.28)^{* *}$ & $(1.99)^{* *}$ & (1.09) & $(2.01) * *$ & $(2.93) * * *$ & $(0.47)$ & $(2.24) * *$ \\
\hline Municipality & -0.06 & -2.71 & -0.06 & -0.02 & -0.06 & -0.02 & -0.01 & -0.14 & -0.01 \\
\hline engagement & $(0.39)$ & $(0.71)$ & $(0.41)$ & $(1.06)$ & $(0.47)$ & $(1.05)$ & $(1.01)$ & $(1.92)^{*}$ & $(0.81)$ \\
\hline Agricultural & -4.73 & & -4.57 & -0.08 & -0.60 & -0.06 & -0.02 & -0.70 & -0.01 \\
\hline practices & $(0.00)$ & & $(0.00)$ & $(1.97)^{* *}$ & $(3.20) * * *$ & $(1.54)$ & $(0.80)$ & $(2.83)^{* * *}$ & $(0.56)$ \\
\hline Agricultural & -0.22 & 5.08 & -0.29 & 0.00 & 0.15 & 0.00 & 0.00 & 0.07 & -0.00 \\
\hline production & $(1.96)^{*}$ & (1.49) & $(2.39)^{* *}$ & $(0.25)$ & $(0.77)$ & $(0.01)$ & $(0.33)$ & $(0.87)$ & $(0.01)$ \\
\hline Gender & -0.21 & & -0.16 & -0.02 & -0.24 & -0.01 & 0.01 & -0.01 & 0.01 \\
\hline & $(0.58)$ & & $(0.43)$ & $(0.63)$ & $(1.81)^{*}$ & $(0.19)$ & $(0.50)$ & $(0.06)$ & (1.06) \\
\hline Post-harvest & 0.18 & 4.45 & -0.04 & 0.01 & 0.22 & 0.00 & -0.00 & 0.22 & -0.01 \\
\hline management & $(0.49)$ & $(0.14)$ & $(0.08)$ & $(0.66)$ & (1.36) & $(0.07)$ & $(0.03)$ & (1.34) & $(0.61)$ \\
\hline Water & 0.06 & -8.02 & 0.13 & -0.01 & 0.06 & -0.01 & -0.00 & 0.09 & -0.00 \\
\hline & $(0.35)$ & $(0.24)$ & $(0.76)$ & $(0.35)$ & $(0.43)$ & $(0.49)$ & $(0.52)$ & $(0.63)$ & $(0.20)$ \\
\hline Environ. & 0.23 & 4.96 & -0.00 & 0.03 & 0.44 & 0.02 & 0.01 & 0.48 & 0.00 \\
\hline management & $(0.61)$ & $(0.85)$ & $(0.01)$ & (1.36) & (1.59) & $(0.78)$ & $(0.77)$ & $(2.74)^{* * *}$ & $(0.24)$ \\
\hline Days & 0.14 & 4.60 & 0.17 & 0.01 & 0.00 & 0.01 & 0.00 & -0.02 & 0.00 \\
\hline participated & $(1.87)^{*}$ & $(1.84)^{*}$ & $(1.97)^{* *}$ & $(0.68)$ & $(0.03)$ & $(0.98)$ & $(0.76)$ & (1.04) & $(1.49)$ \\
\hline Cost of & -0.02 & -0.90 & -0.02 & -0.00 & 0.00 & -0.00 & -0.00 & 0.00 & -0.00 \\
\hline intervention & $(2.10)^{* *}$ & (1.19) & $(1.75)^{*}$ & $(2.01)^{* *}$ & $(0.19)$ & $(2.02)^{* *}$ & $(0.28)$ & (1.14) & $(0.71)$ \\
\hline Production area & 0.10 & 0.97 & 0.09 & 0.01 & 0.01 & 0.01 & 0.01 & -0.02 & 0.01 \\
\hline & $(1.92)^{*}$ & $(0.28)$ & $(1.75)^{*}$ & $(2.39)^{* *}$ & $(0.30)$ & $(2.42)^{* *}$ & $(3.22) * * *$ & $(0.90)$ & $(3.89) * * *$ \\
\hline Production cost & -0.00 & -0.17 & -0.00 & -0.00 & -0.00 & -0.00 & -0.00 & 0.00 & -0.00 \\
\hline & $(1.25)$ & $(2.00)^{* *}$ & $(0.78)$ & (1.37) & $(0.30)$ & $(1.25)$ & $(2.43)^{* *}$ & $(0.70)$ & $(2.53) * *$ \\
\hline Pseudo- $R^{2}$ & 0.82 & 0.70 & 0.84 & & & & & & \\
\hline$R^{2}$ (within) & & & & 0.07 & 0.35 & 0.08 & 0.06 & 0.36 & 0.06 \\
\hline$N$ & 4,755 & 168 & 4,587 & 4,755 & 168 & 4,587 & 2,409 & 108 & 2,301 \\
\hline
\end{tabular}

Source: Authors' calculation 
Regarding the number of total capacity building days participated by individual producers, we are unable to confirm its effect. The results show positive and statistically significant coefficients for all groups when estimated using the panel probit method. However, the effect does not show up when using both of the LPMs. As discussed earlier, applying LPM is argued more appropriate than nonlinear models when there is individual heterogeneity (Wooldridge, 2010). Therefore, we are unable to conclude the effect of overall participation in intervention activities on commercialization in linked markets.

Besides the project intervention variables, production area is positively and statistically significantly correlated with commercialization of beans. All estimation models show that Group 2 farmers show the same trend while Group 1 farmers do not. For instance, the panel probit model suggests that an increase in production area by one ha is associated with an increase in the probability of market participation by 10 and 9 percentage points for all and Group 2 farmers, respectively. Similarly, the LPMs show that the probability increases by 1 percentage point for both all and Group 1 producers when production area increases by one ha. This suggests the importance of land size in initiating commercialization, which is consistent with findings in the empirical literature. However, once producers enter commercial markets, the area size increase no longer matters.

Second, Table 4.3 presents the regression results at the intensive margins. All presented results are corrected for serial autocorrelation. Columns 4 through 6 show the results of the models with village fixed effects while models in Columns 7 through 9 are estimated with village and cooperative fixed effects. All models show that the entrepreneurial practices activities show positive and statistically significant relationship to the outcome variable, quantity of beans sold in linked markets, for all farmers and those in Group 2. In the case of Group 2 farmers, individuals who received trainings in entrepreneurial practices on average sell 3.90qq more beans to linked markets than those who did not receive trainings when estimated in a serial autocorrelation-corrected DID model (Column 3). When village and cooperative fixed effects are taken into account, the effect becomes 3.46qq and 2.44qq (Column 6 and 9, respectively). The statistical significance of these estimated coefficients remain significant. Therefore, we confirm the positive influence of the entrepreneurial practices activities on bean sales in non-local markets particularly for those who had not been linked to non-local markets prior to the program intervention.

The standard DID model and DID with village fixed effect results indicate that only observations of those in Group 1 are positively and statistically significantly correlated with activities in environmental management. It is possible that those in Group 1 were able to benefit from environmental sustainability program since their production system had been relatively advanced prior to the interventions. Its marginal effects estimated in both models are also large. Receiving the environmental management interventions is associated with an increase in the quantity sold in linked markets by 4.66qq and 4.01qq in the standard DID model and model with village fixed effect, respectively. As our estimation method only allows us to elicit ATT, however, we are unable to identify whether this indicates reverse causality or not. 
4. Intensive and Extensive Margins of NGO Interventions

Table 4.3. Regression results: intensive margin (t-values in brackets)

\begin{tabular}{|c|c|c|c|c|c|c|c|c|c|}
\hline & \multicolumn{3}{|c|}{ Serial autocorrelation-corrected DID } & \multicolumn{3}{|c|}{ w/ village fixed effect } & \multicolumn{3}{|c|}{ w/ village and cooperative fixed effect } \\
\hline & $\begin{array}{l}\text { All } \\
(1) \\
\end{array}$ & $\begin{array}{c}\text { Group } 1 \\
(2) \\
\end{array}$ & $\begin{array}{c}\text { Group } 2 \\
\text { (3) }\end{array}$ & $\begin{array}{l}\text { All } \\
(4)\end{array}$ & $\begin{array}{l}\text { Group } 1 \\
(5)\end{array}$ & $\begin{array}{c}\text { Group } 2 \\
(6)\end{array}$ & $\begin{array}{l}\text { All } \\
(7) \\
\end{array}$ & $\begin{array}{c}\text { Group } 1 \\
(8)\end{array}$ & $\begin{array}{c}\text { Group } 2 \\
(9)\end{array}$ \\
\hline $\begin{array}{l}\text { Entrepreneurial } \\
\text { practices }\end{array}$ & $\begin{array}{c}3.73 \\
(3.41)^{* * *}\end{array}$ & $\begin{array}{r}0.62 \\
(0.32)\end{array}$ & $\begin{array}{r}3.90 \\
(3.44)^{* * *}\end{array}$ & $\begin{array}{c}3.30 \\
(3.33)^{* * *}\end{array}$ & $\begin{array}{r}-0.25 \\
(0.16)\end{array}$ & $\begin{array}{r}3.46 \\
(3.36)^{* * *}\end{array}$ & $\begin{array}{c}2.30 \\
(2.74)^{* * *}\end{array}$ & $\begin{array}{r}-0.74 \\
(0.49)\end{array}$ & $\begin{array}{r}2.44 \\
(2.79)^{* * *}\end{array}$ \\
\hline $\begin{array}{l}\text { Municipality } \\
\text { engagement }\end{array}$ & $\begin{array}{c}-3.48 \\
(5.46)^{* * *}\end{array}$ & $\begin{array}{l}-1.85 \\
(0.95)\end{array}$ & $\begin{array}{r}-3.47 \\
(5.30)^{* * *}\end{array}$ & $\begin{array}{c}-2.19 \\
(3.70)^{* * *}\end{array}$ & $\begin{array}{l}-2.08 \\
(1.32)\end{array}$ & $\begin{array}{r}-2.15 \\
(3.55)^{* * *}\end{array}$ & $\begin{array}{c}-1.76 \\
(3.12)^{* * *}\end{array}$ & $\begin{array}{r}-1.69 \\
(1.07)\end{array}$ & $\begin{array}{r}-1.79 \\
(3.07)^{* * *}\end{array}$ \\
\hline $\begin{array}{l}\text { Agricultural } \\
\text { practices }\end{array}$ & $\begin{array}{l}-1.42 \\
(1.55)\end{array}$ & $\begin{array}{r}-0.51 \\
(0.15)\end{array}$ & $\begin{array}{r}-1.45 \\
(1.59)\end{array}$ & $\begin{array}{c}1.79 \\
(1.83)^{*}\end{array}$ & $\begin{array}{l}-3.32 \\
(1.17)\end{array}$ & $\begin{array}{r}1.84 \\
(1.87)^{*}\end{array}$ & $\begin{array}{r}0.86 \\
(1.03)\end{array}$ & $\begin{array}{r}-5.82 \\
(1.70)^{*}\end{array}$ & $\begin{array}{r}0.89 \\
(1.07)\end{array}$ \\
\hline $\begin{array}{l}\text { Agricultural } \\
\text { production }\end{array}$ & $\begin{array}{c}-2.88 \\
(5.39)^{* * *}\end{array}$ & $\begin{array}{r}-4.08 \\
(2.10)^{* *}\end{array}$ & $\begin{array}{r}-2.85 \\
(5.25)^{* * *}\end{array}$ & $\begin{array}{l}-0.42 \\
(0.86)\end{array}$ & $\begin{array}{l}-2.28 \\
(1.52)\end{array}$ & $\begin{array}{r}-0.37 \\
(0.74)\end{array}$ & $\begin{array}{l}-0.19 \\
(0.43)\end{array}$ & $\begin{array}{r}-1.64 \\
(1.10)\end{array}$ & $\begin{array}{r}-0.17 \\
(0.37)\end{array}$ \\
\hline Gender & $\begin{array}{c}-5.15 \\
(4.02)^{* * *}\end{array}$ & $\begin{array}{r}-0.33 \\
(0.19)\end{array}$ & $\begin{array}{r}-5.22 \\
(4.09)^{* * *}\end{array}$ & $\begin{array}{c}-4.93 \\
(3.61)^{* * *}\end{array}$ & $\begin{array}{r}0.90 \\
(0.56)\end{array}$ & $\begin{array}{r}-4.99 \\
(3.64)^{* * *}\end{array}$ & $\begin{array}{c}-4.09 \\
(2.83)^{* * *}\end{array}$ & $\begin{array}{r}0.94 \\
(0.67)\end{array}$ & $\begin{array}{r}-4.20 \\
(2.85)^{* * *}\end{array}$ \\
\hline $\begin{array}{l}\text { Post-harvest } \\
\text { management }\end{array}$ & $\begin{array}{c}0.39 \\
(0.45)\end{array}$ & $\begin{array}{r}3.62 \\
(2.07)^{* *}\end{array}$ & $\begin{array}{r}0.42 \\
(0.48)\end{array}$ & $\begin{array}{c}-1.89 \\
(1.88)^{*}\end{array}$ & $\begin{array}{r}1.38 \\
(0.92)\end{array}$ & $\begin{array}{r}-1.87 \\
(1.84)^{*}\end{array}$ & $\begin{array}{c}-2.64 \\
(2.00)^{* *}\end{array}$ & $\begin{array}{r}0.08 \\
(0.03)\end{array}$ & $\begin{array}{r}-2.65 \\
(1.96)^{* *}\end{array}$ \\
\hline Water & $\begin{array}{c}0.92 \\
(1.13)\end{array}$ & $\begin{array}{r}-3.31 \\
(1.05)\end{array}$ & $\begin{array}{r}0.92 \\
(1.11)\end{array}$ & $\begin{array}{l}-0.10 \\
(0.12)\end{array}$ & $\begin{array}{r}0.09 \\
(0.04)\end{array}$ & $\begin{array}{r}-0.10 \\
(0.13)\end{array}$ & $\begin{array}{c}-0.18 \\
(0.25)\end{array}$ & $\begin{array}{r}3.46 \\
(1.15)\end{array}$ & $\begin{array}{r}-0.17 \\
(0.22)\end{array}$ \\
\hline $\begin{array}{l}\text { Environ. } \\
\text { management }\end{array}$ & $\begin{array}{c}0.77 \\
(1.14)\end{array}$ & $\begin{array}{r}4.66 \\
(3.39)^{* * *}\end{array}$ & $\begin{array}{r}0.69 \\
(0.99)\end{array}$ & $\begin{array}{l}-0.54 \\
(0.69)\end{array}$ & $\begin{array}{r}4.01 \\
(2.56)^{* *}\end{array}$ & $\begin{array}{r}-0.65 \\
(0.80)\end{array}$ & $\begin{array}{r}0.35 \\
(0.58)\end{array}$ & $\begin{array}{r}2.00 \\
(0.92)\end{array}$ & $\begin{array}{r}0.32 \\
(0.52)\end{array}$ \\
\hline $\begin{array}{l}\text { Days } \\
\text { participated }\end{array}$ & $\begin{array}{c}0.78 \\
(2.27)^{* *}\end{array}$ & $\begin{array}{r}-0.44 \\
(0.47)\end{array}$ & $\begin{array}{r}0.89 \\
(2.41)^{* *}\end{array}$ & $\begin{array}{r}0.15 \\
(0.45)\end{array}$ & $\begin{array}{r}-0.70 \\
(0.80)\end{array}$ & $\begin{array}{r}0.24 \\
(0.67)\end{array}$ & $\begin{array}{r}0.38 \\
(1.10)\end{array}$ & $\begin{array}{r}-0.43 \\
(0.49)\end{array}$ & $\begin{array}{r}0.48 \\
(1.28)\end{array}$ \\
\hline $\begin{array}{l}\text { Cost of } \\
\text { intervention }\end{array}$ & $\begin{array}{c}-0.05 \\
(1.80)^{*}\end{array}$ & $\begin{array}{r}0.20 \\
(1.49)\end{array}$ & $\begin{array}{r}-0.07 \\
(2.31)^{* *}\end{array}$ & $\begin{array}{c}-0.06 \\
(2.27)^{* *}\end{array}$ & $\begin{array}{r}0.19 \\
(1.67)^{*}\end{array}$ & $\begin{array}{r}-0.08 \\
(2.66)^{* * *}\end{array}$ & $\begin{array}{c}-0.07 \\
(2.15)^{* *}\end{array}$ & $\begin{array}{r}0.16 \\
(1.33)\end{array}$ & $\begin{array}{r}-0.08 \\
(2.48)^{* *}\end{array}$ \\
\hline Constant & $\begin{array}{c}1.12 \\
(2.79)^{* * *}\end{array}$ & $\begin{array}{r}0.90 \\
(0.75) \\
\end{array}$ & $\begin{array}{r}1.10 \\
(2.68)^{* * *}\end{array}$ & $\begin{array}{r}0.40 \\
(1.12) \\
\end{array}$ & $\begin{array}{r}2.12 \\
(2.03)^{* *}\end{array}$ & $\begin{array}{r}0.34 \\
(0.94) \\
\end{array}$ & $\begin{array}{r}0.29 \\
(0.91) \\
\end{array}$ & $\begin{array}{r}1.77 \\
(1.68)^{*} \\
\end{array}$ & $\begin{array}{r}0.24 \\
(0.74) \\
\end{array}$ \\
\hline$R^{2}$ (within) & 0.02 & 0.11 & 0.02 & 0.01 & 0.10 & 0.02 & 0.02 & 0.09 & 0.02 \\
\hline$N$ & 4,755 & 168 & 4,587 & 4,755 & 168 & 4,587 & 4,755 & 168 & 4,587 \\
\hline
\end{tabular}

$* p<0.1 ; * * p<0.05 ; * * * p<0.01$

Source: Authors' calculation 


\subsection{Discussion}

The econometric results at the intensive and extensive margins suggest that the entrepreneurial practices activities demonstrate positive and statistically significant correlation with the measures of market linkage in general. All results at both margins confirm that particularly those who had not been part of the commercialization in non-local market prior to the program intervention benefitted more than those who had sold beans in such dynamic markets. We also find that area size matters for entrant farmers when beginning to commercialize but not for those who had already supplied to linked markets before the interventions. This is consistent with the empirical literature arguing that staple commodity marketing requires relatively large land area and wealth to produce enough quantity to supply the family and have surplus to sell outside the household (Barrett, 2008).

The municipality engagement activities were not found effective. They were mainly designed to provoke changes at the regional-, or meso-, level by working closely with local governments. The literature argues that, at the meso-level, marketing transaction costs should be lowered through improving infrastructure, establishing mechanisms to comply with contracts and agreements, and encouraging spatial price transmission and competition among buyers (Barrett, 2008). However, it is a complex task that is likely to require time and thorough change at all levels. Therefore, the effect may not have been as visible as in the case of entrepreneurial practices activities due to the lack of time after the intervention took place as well as the complexity of required support at all levels.

Regarding entrepreneurial practices, our findings suggest substantial heterogeneity among producers when realizing their benefits. As shown in the descriptive statistics, farmers who had not supplied in linked markets in 2006 and 2007 demonstrate lower production yield and less marketing diversification than those in Group 1. Therefore, the interventions were successful in linking those who had been outside linked markets. In other words, the program fulfilled its major objective.

Our result not only indicates the positive correlation between program participation and commercialization of beans but also suggests that training those already commercializing may not be necessary. There are a total of 613 activities were undertaken in the entrepreneurial practices category, 16 of which were allocated to those in Group 1. For future implementation of similar programs, development agencies may choose to focus solely on those who had not commercialized prior to interventions, thereby maximizing the outreach of activities to those who benefit the most.

Caution must be taken, however, to draw conclusions as to how effective the market linkage program was and will be. Smallholder commercialization must be facilitated at multiple policy levels (Barrett, 2008; Barrett \& Swallow, 2006; Stoian et al., 2012). Producers who do not have production and institutional capacity to participate in commercialization are unlikely to benefit from interventions before obstacles are overcome (Stoian et al., 2012). Moreover, the semisubsistence farming with crop diversification is a result of strategic thinking to secure income 
and food sources (Omamo, 1998a). Therefore, future development projects must assess ex-ante empirical contexts in order to maximize their outcome and allocate implementation resources efficiently.

We acknowledge the limitations of our study. We are unable to control for selection bias into receiving NGO-based activities among producers in the sample given our data set. To overcome this problem, future research must obtain information on producers outside the NGO project participants in order to derive average treatment effect (ATE) rather than ATT as in our study. Moreover, we lack a number of variables regarding individual and household characteristics such as education level, age of producers, household assets, and conditions of transportation infrastructure to name a few. These variables may enable more comprehensive econometric approaches (e.g. application of instrumental variables).

In addition, lack of observations outside project participants prevents us from investigating how those whose productivity is below the national average would respond to treatments. From Table 4.1, we know that beneficiaries of the project demonstrate higher productivity than the rest of the country. In order to target those with enough capacity, future studies may address characteristics of producers who benefit from interventions most. This is beyond the scope of our research.

\subsection{Conclusions}

Evidences suggest that heterogeneity among small producers in developing countries is a key to understanding how donor-funded projects can facilitate commercialization by small farmers, and therefore poverty reduction, in rural areas. In this notion, we extend the findings from the previous chapter to assess whether NGO-based effort to enable commercialization was received differently by farmers who had been linked to non-local markets and those who had not before the intervention was undertaken. Borrowing the concept of intensive and extensive margins from the trade literature, we study the probability and magnitude of commercialization. The analysis is conducted, using an unbalanced panel data of more than 5,000 farmers who produced staple beans between 2006 and 2012 in rural Nicaragua.

We find that farmers who had sold in linked markets prior to program interventions demonstrate higher productivity and more diversification in commercial activities than those who did not. Less producers who had commercialized before the interventions are female and/or household heads. There was no farmer in a leading position of a cooperative among those who sold in linked markets in 2006 and 2007. For both groups of producers, approximately 12-15\% received the interventions.

The activities in "entrepreneurial practices" category are positively and statistically significantly correlated with both the probability and magnitude of commercialization. Entrant farmers benefitted from the interventions at both margins while those who had been linked to non-local markets before did not show any effect. Given that entrants are less productive and engaged in commercialization of multiple crops, the program was successful in linking those who had faced obstacles prior to the interventions. 
While our results indicate that donor-funded projects may prioritize entrant farmers over those already in linked markets, care is needed in coming to such conclusion. Enabling small farmers to commercialize poses a number of challenges at the micro-, meso- and macro-levels. When most, if not all, enabling conditions are not met, project interventions are likely to bring little positive effect on participants. Thus, development projects must analyze empirical obstacles prior to implementation and identify effective pathways to assist commercialization in rural areas.

We acknowledge the limitation in our study. We are unable to obtain information on producers outside the project participants. Therefore, it is only possible to obtain ATT with the available data. Moreover, we lack a number of variables that may allow more complex and comprehensive analyses such as application of instrumental variables. Future research is encouraged to overcome such challenges. 


\section{Conclusions}

As outlined in the introduction, agricultural development and commercialization is crucial in order to achieve poverty reduction and economic development. In this context, this thesis motivates providing policy makers with clear guidance as to what intervention activities are most effective in promoting smallholder commercialization by how much. The present work approaches this question from two distinct aspects that have not received adequate attention. All analyses were conducted, using an unbalanced panel data of a total of approximately 5,000 small-scale bean producers in rural Nicaragua.

The first shortcoming addressed is quantification of benefits realized from rural road infrastructure development at the household level as pointed out in Jacoby \& Minten (2009) and Jacoby (2000). Investigating bean producer prices, Chapter 2 quantifies benefit gained by smallholder farmers through reducing transportation costs measured in time and distance traveled. The result indicates that decreasing travel time by $25 \%$ would increase bean producer prices by between $3 \%$ and $12 \%$. In absolute terms, this translates to an increase in bean sales income of between \$24 and \$110 per year per household. As this figure ignores effects reaching producers outside the sample, all crops but staple beans and other industries, the actual monetary benefits is expected to be higher than derived in our study. Thus, we challenge the view expressed by studies solely based on transportation costs (e.g. Jacoby \& Minten (2009), Jacoby (2000)) that benefits from rural road development are small at the household-level.

Further, we shed light on estimating effectiveness of donor-funded development projects, another overlooked aspect of smallholder commercialization in the literature. Using detailed records of NGO-based activities, Chapter 3 differentiates intervention activities with distinct objectives. We test if activities related to marketing practices had positive influence on market linkage. Market linkage is measured with the volume of beans sold in linked markets. Using difference-in-differences approach corrected for serial autocorrelation, we find that the marketing-related activities show positive effect on market linkage. Participating in entrepreneurial training increases bean sales volume to dynamic markets by between 0.2 and 0.5 percentage points. Furthermore, our analysis indicates that the larger the proportion of beans sold in dynamic markets is, the higher annual bean income becomes. Therefore, the effect of marketing-related activities participation extends to welfare increase.

Chapter 4 builds up on the findings from Chapter 3 and investigates heterogeneity among producers in taking advantage of intervention activities. We divide all bean producers into two groups: those who had commercialized in dynamic markets prior to project interventions and those who had not. Referring to the trade literature, we test whether marketing-related activities show positive influence on commercialization at the intensive and extensive margins. The result suggests a positive linkage between intervention activities and commercialization only for those who had not participated before, confirming heterogeneous responses to treatment.

In summary, this thesis provides 1 . quantification of benefit from road infrastructure development from the farm-gate price aspect, and 2. guidance as to what intervention has positive effect on smallholder commercialization. As any institution is constrained with limited 
budget, our findings can lead policy makers to strategically place intervention resources to where assistance is most needed and effective.

We acknowledge the limitations of our studies. Information on non-participants of the project is not available. This is a shortcoming that future research should address with sampling strategy prior to project interventions. While NGOs and donor-funded projects often possess bulky information that can be used for academic research, they tend to allocate only a small fraction of total budget on monitoring and evaluation (Humphrey \& Navas-Alemán, 2010). Therefore, (longitudinal) data collection must be an initiative from research-oriented institutions. Moreover, selection of beneficiaries is seldom, if not never, random (Barrett, 2008). Thus, utilization of such data must address selection bias early on so that appropriate estimation strategy can be applied through instrumental variables approach and/or matching techniques. Future research may overcome such problems by establishing a long-term partnership between research-based organizations and grassroots institutions that implement interventions.

Another suggestion for future research is careful identification of potential "survivors" as agricultural producers. As pointed out in the introductory chapter, shrinking the share of the agricultural sector as source of both income and employment is central to achieving agricultural development and commercialization (Timmer, 1988). In other words, the majority of smallholder farmers must be encouraged to exit agriculture in the long-run in order to reduce poverty (Barrett, 2008). This is demonstrated with the emergence of vertical integration and increased trade. Exiting agricultural production yet participating as labor is found to have positive effect on poverty reduction (Maertens \& Swinnen, 2009). In this context, the empirical challenge is to identify who are potential surviving producers. With the existing data set, however, we are unable to draw link between specific characteristics and capacities of survival as agricultural producers. Thus, future research may identify characteristics of current smallholders who remain and exit agricultural production or agricultural sector completely in order to achieve alleviation of poverty. 


\section{Annex}

\subsection{Description of the project ACORDAR: 2007-2012}

This dissertation utilizes data collected by CRS as a part of monitoring and evaluation for a project called Alliance to Create Rural Business Opportunities through Agro-Enterprise Relationships (ACORDAR). This section provides details of the project.

\subsubsection{General background}

ACORDAR was funded by the United States Agency for International Development (USAID) and a few other international NGOs. The entire project lasted for five years between September 2007 and October 2012, with two 30-month-long project phases. The official project report says that there were a total of 7,000 participants over the 5 years. The first phase targeted 5,400 producers, which was extended to include another 1,600 farmers for the second phase. In reality, the project worked with approximately 10,000 farmers. This was because some farmers dropped out of the project due to emigration, death, unwillingness to continue participating, terminating agricultural production, and so on. Since the project needed to maintain the number of farmers they are working with at a time, the NGO recruited new participants to replace the dropouts.

Figure 6.1. Map of Nicaragua with departments

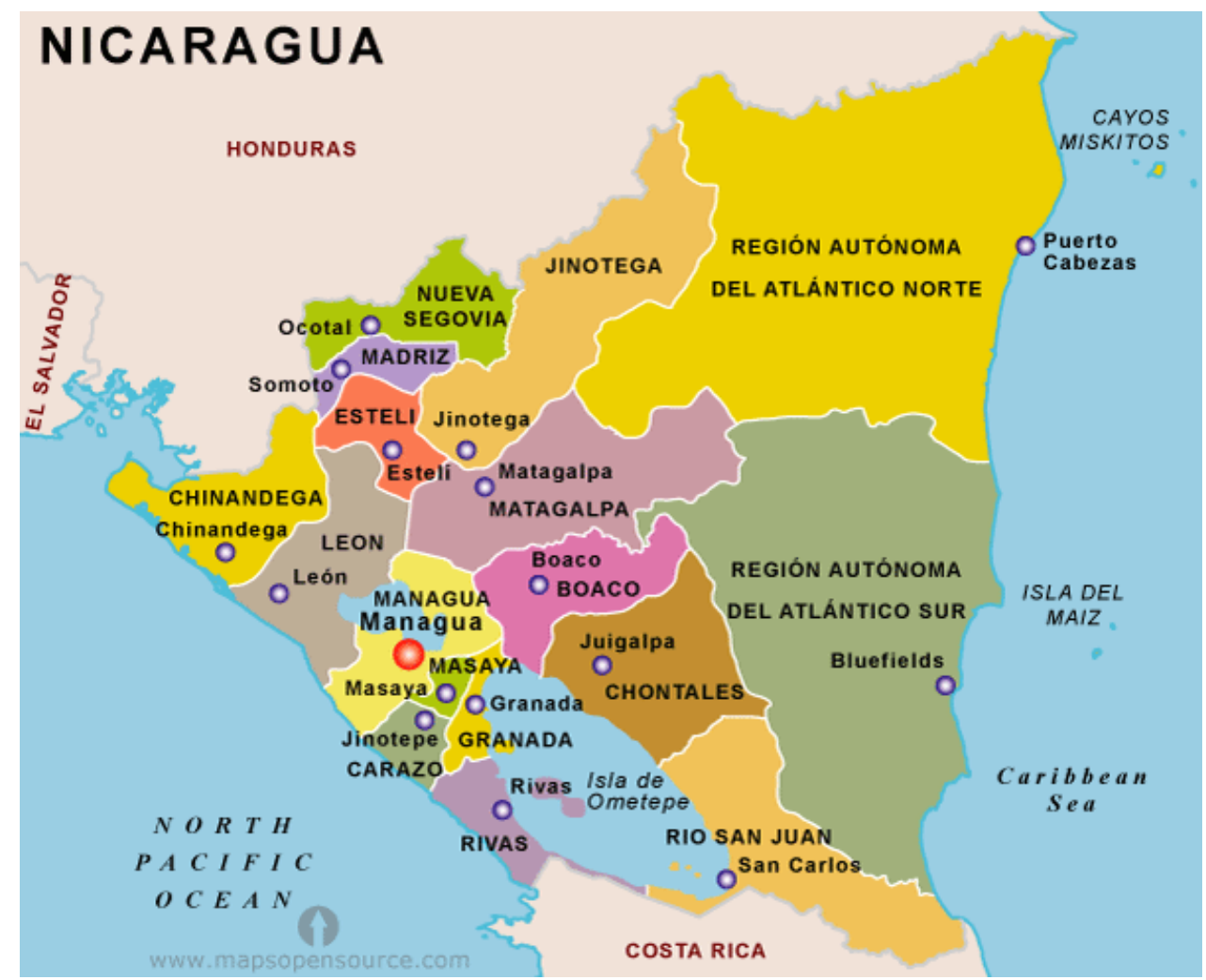

Source: http://www.mapsopensource.com/nicaragua-map.html 
Participating producers are located throughout Nicaragua. At the departmental level, the project worked in the capital region (Managua), the northern highlands (Estelí, Jinotega, Madriz, Matagalpa, Nueva Segovia), the Rio San Juan region (Boaco), the southern pacific coast (Rivas) and the Caribbean regions (Región Autónoma del Atlántico Norte (RAAN), Región Autónoma del Atlántico Sur (RAAS)). The majority of producers are located in the departments of Estelí, Jinotega and Matagalpa. The project targeted producers of cacao, coffee, beans, vegetables, fruits, and roots and tubers. Vegetables included tomatoes, onions, cabbage and cucumbers while fruits can be papaya, pineapple, orange and so on. Roots and tubers are mainly potatoes, cassava, malanga, and carrots amongst others.

Nicaragua's national statistics show that the project targeted commodities of importance in agriculture-based regions. Table 6.1 shows the results of the national census conducted in 2011. Jinotega, Matagalpa, RAAN and RAAS are amongst the largest departments in terms of total agricultural land area. We can also see that large amount of land are used for production of maize, beans, coffee, cacao, cassava, malanga and vegetable crops.

Figure 6.2 shows the composition of project funding based on its sources. USAID granted the project with a total of US\$9,530,391 for the first phase (from September 2007 to March 2010). For the second phase (from April 2010 to October 2012), the fund from the USAID was US\$9,256,821, which gives a total of US\$18,787,212 from USAID for ACORDAR. On top of the donation from USAID, the project has received additional US\$2,925,713 from CRS counterparts as well as US\$31,282,955 of leveraged funds. Therefore, over the course of entire project implementation, CRS has received a total of US\$52,995,880.

Figure 6.2. Project funding distribution: September 2007-October 2012

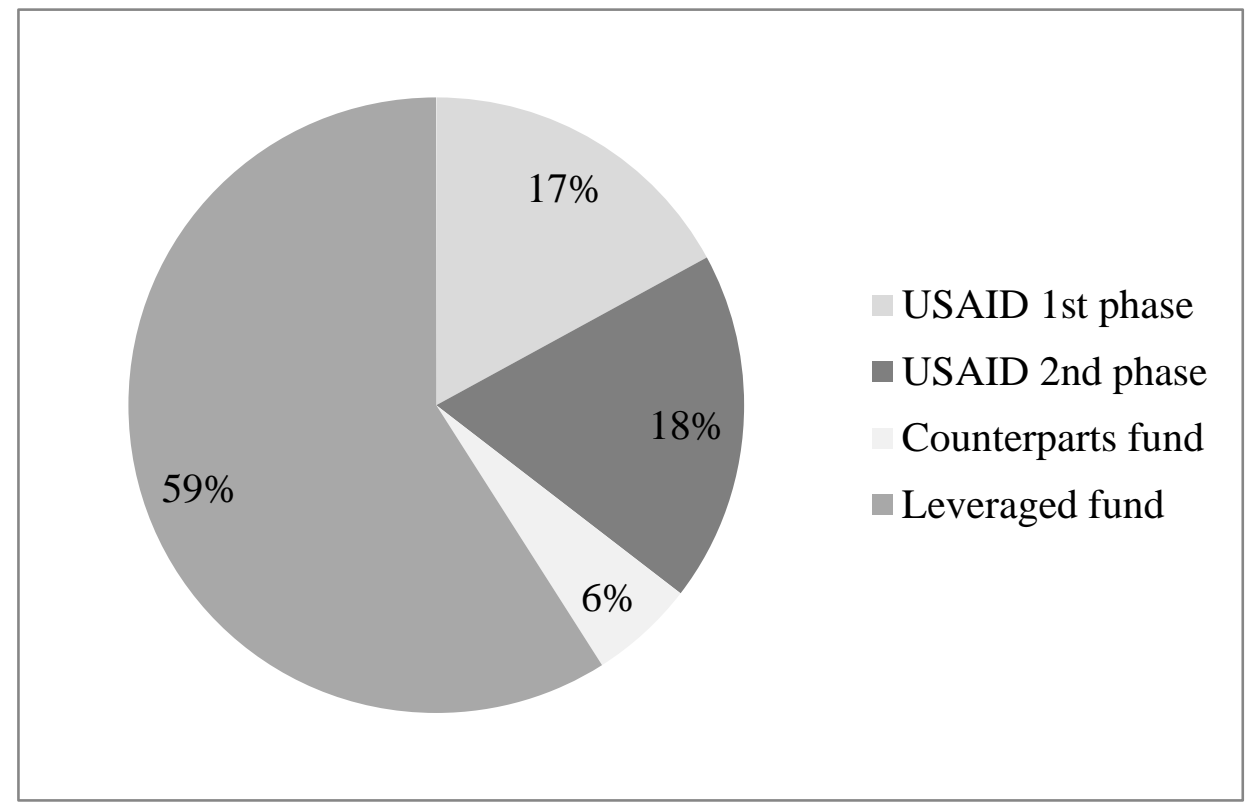

Source: Escoto et al. (2012) 
Table 6.1. Agricultural area (Ha) reported in the national statistics: 2011 census

\begin{tabular}{|c|c|c|c|c|c|c|c|c|c|c|c|c|}
\hline \multirow{2}{*}{ Department } & \multirow{2}{*}{$\begin{array}{c}\text { Total } \\
\text { agricultural } \\
\text { land* } \\
\end{array}$} & \multicolumn{3}{|c|}{ Basic grains } & \multicolumn{3}{|c|}{ Permanent/semi-permanent crops } & \multicolumn{5}{|c|}{ Others } \\
\hline & & Total & Maize & Bean & Total & Coffee & Cacao & Total & Cassava & Malanga & Tomato & Zucchini \\
\hline Nueva Segovia & 12,488 & 9,163 & 8,652 & 8,463 & 19,691 & 17,632 & 64 & 1,021 & 179 & 73 & 198 & 18 \\
\hline Jinotega & 21,352 & 15,401 & 14,717 & 14,093 & 52,880 & 43,866 & 1,017 & 3,249 & 945 & 670 & 432 & 15 \\
\hline Madriz & 9,676 & 7,034 & 6,700 & 6,182 & 10,934 & 10,000 & 49 & 568 & 64 & 15 & 126 & 40 \\
\hline Estelí & 7,710 & 6,248 & 5,843 & 5,296 & 3,359 & 2,517 & 2 & 1,129 & 13 & 16 & 372 & 96 \\
\hline Chinandega & 10,819 & 7,531 & 7,064 & 1,781 & 50,218 & 363 & 21 & 1,501 & 301 & 5 & 65 & 330 \\
\hline León & 12,865 & 7,937 & 7,401 & 2,528 & 5,178 & 118 & 3 & 1,567 & 1,155 & 14 & 56 & 286 \\
\hline Matagalpa & 20,445 & 16,246 & 15,246 & 14,163 & 40,109 & 32,085 & 2,898 & 3,734 & 1,124 & 391 & 358 & 188 \\
\hline Boaco & 8,791 & 6,241 & 5,947 & 4,951 & 7,493 & 3,997 & 24 & 1,312 & 411 & 288 & 105 & 40 \\
\hline Managua & 9,244 & 5,671 & 5,124 & 2,585 & 11,026 & 4,858 & 18 & 1,485 & 438 & 4 & 262 & 358 \\
\hline Masaya & 10,493 & 3,201 & 2,518 & 2,324 & 8,648 & 2,274 & 36 & 1,585 & 736 & 4 & 159 & 367 \\
\hline Chontales & 5,890 & 3,569 & 3,352 & 2,728 & 2,297 & 34 & 29 & 1,193 & 511 & 110 & 50 & 32 \\
\hline Granada & 3,954 & 1,926 & 1,454 & 1,450 & 6,538 & 1,411 & 38 & 503 & 208 & 2 & 71 & 109 \\
\hline Carazo & 5,603 & 3,412 & 2,812 & 2,620 & 8,226 & 4,695 & 17 & 576 & 144 & 0 & 47 & 35 \\
\hline Rivas & 8,618 & 4,803 & 3,556 & 3,497 & 14,802 & 92 & 10 & 687 & 160 & 4 & 53 & 108 \\
\hline Río San Juan & 6,433 & 4,808 & 4,439 & 4,204 & 10,625 & 47 & 984 & 1,548 & 831 & 95 & 8 & 9 \\
\hline RAAN & 14,461 & 12,507 & 11,280 & 10,644 & 17,568 & 2,646 & 4,408 & 6,998 & 5,248 & 829 & 55 & 10 \\
\hline RAAS & 15,991 & 11,758 & 11,158 & 9,558 & 23,955 & 239 & 1,473 & 8,957 & 9,628 & 1,256 & 59 & 27 \\
\hline
\end{tabular}

*The sum of all land use exceeds the total agricultural land because intercropped areas are double-counted.

Source: INIDE (2011) 
The project's objectives were:

- To increase net income of $75 \%$ of a total of 7,000 small producers by $20 \%$ compared to the baseline;

- To create permanent employment opportunities in the participating communities;

- To strengthen commercial capacity of producers;

- To develop value chains by training 6,328 producers on topics related to value chains;

- To produce 9,094 hectares of production area with improved management practice technologies.

\subsubsection{Selection process of beneficiaries}

Reports submitted by CRS to USDA over the five years provide useful information regarding the selection process of project participants. Beneficiaries of the project were selected, following four steps. The project was designed to be implemented through consortium members (so-called "socios"), sub-consortium members ("sub-socios"), and farmer cooperatives. Therefore, the project first selected consortium members, which then selected several subconsortium members. The chosen sub-consortium members selected local farmer cooperatives, which nominated individual farmers to be participants. Despite the selection process based on cooperatives, beneficiaries include a small fraction of individuals who do not belong to cooperatives Table 6.2 shows that about $90 \%$ of beneficiaries were members of a cooperative. Producers are not able to belong to more than one cooperative. Therefore, there is no duplication in counting cooperative members.

Table 6.2. Number and percentage of the project participants who belong to a cooperative

\begin{tabular}{lcccccccc}
\hline Year/Coop & 2006 & 2007 & 2008 & 2009 & 2010 & 2011 & 2012 & Total \\
\hline Coop & 423 & 2,257 & 5,413 & 3,782 & 3,132 & 3,695 & 3,495 & 22,197 \\
Total & 505 & 2,508 & 5,639 & 4,276 & 3,551 & 4,255 & 3,743 & 24,477 \\
\% coop & 83.8 & 90.0 & 96.0 & 88.5 & 88.2 & 86.8 & 93.4 & 90.7
\end{tabular}

Source: CRS data base modified by authors

Figure 6.3 visualizes the selection process. The project worked with a total of three consortium members, 14 sub-consortium members, and 178 cooperatives. The criteria that the project imposed on producer characteristics to be participants for the first phase are as follows.

1. Producers must possess less than 10 hectares of land in an ecologically vulnerable area of the project's targeted areas;

2. Producers must be engaged in the production of one or more of the targeted commodities;

3. Producers must be facing technical difficulties such as low production yields and lack of access to appropriate inputs. In addition, they must be applying low technology for agricultural production as well as processing of commodities;

4. Producers must have limited ability to compete in commercial markets due to poor infrastructure for post-harvest management, lack of information about markets, poor organizational structure, and lack of physical as well as financial capitals. 
Figure 6.3. Selection process of project participants

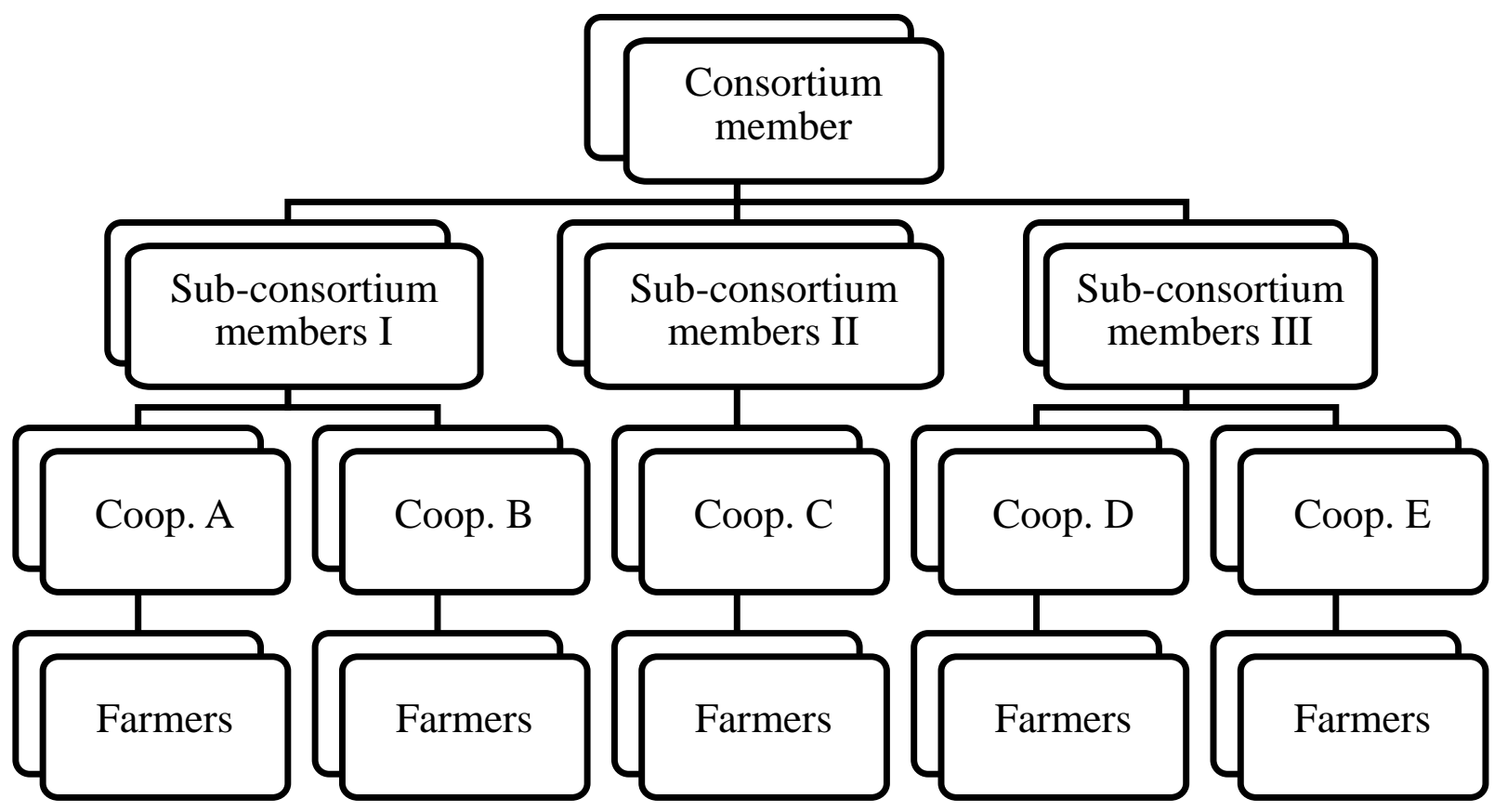

Source: Escoto et al. (2012) depicted by authors

Through the selection process, local cooperatives have identified producers who fulfill these criteria.

Since the project was first granted with funding for 30 months, the project first worked with 5,400 producers. After the 30 months, a new set of participants was selected, which gave a total of 7,000 participants. The selection for the second phase was not identical to that of the first phase, which needs some attention. Besides the aforementioned criteria used during the first phase, additional conditions were imposed on the new participants starting in the second phase. Namely, new-coming cooperatives must:

1. have the potential to achieve financial and institutional development in the time remaining until the end of the project;

2. be capable of identifying market opportunities and developing linkages to expand their commercial activities;

3. have the capacity and willingness to work with other cooperatives to enforce marketing channels by sharing infrastructure (e.g. post-harvest processing centers) as well as market contacts;

4. be able to expand organizational size by integrating producers who possess economic potentials ${ }^{14}$.

The selection of ACORDAR beneficiaries was done from two different aspects (Escoto et al., 2012). The first is to reach poor farmers who face unfavorable production, processing and marketing conditions. The second is to develop producer organizations as successful business

\footnotetext{
${ }^{14}$ This criterion was applied particularly for the cacao value chain as it was not included as one of the targeted value chains to be developed during the first phase.
} 
enterprises. As mentioned above, the project was granted two 30-month-long project funding. However, CRS was not certain whether the funding would be renewed after the first phase. As a result, the selection of beneficiaries included those who are struggling to participate in markets and those who already had experiences and resources in establishing as well as maintaining business relationships with buyers. For the second phase, preference towards alreadyestablished individuals was even stronger. As the project intervention team knew that there was no second extension and therefore the project has to come to an end after two and half years, individuals and cooperatives with more potential were selected compared with the first phase. The next section will go into details of producer characteristics in order to understand potential selection biases that were applied to the project participants.

\subsubsection{Project beneficiaries}

As mentioned above, project beneficiaries were located throughout the country, yet the majority is found in the departments of Estelí, Jinotega and Matagalpa (Table 6.3).

Table 6.3. Number of the project participants by department: 2006-2012

\begin{tabular}{lccccccc}
\hline Year/Dep. & 2006 & 2007 & 2008 & 2009 & 2010 & 2011 & 2012 \\
\hline Boaco & - & - & - & - & 82 & 87 & 54 \\
Estelí & 287 & 610 & 791 & 974 & 677 & 928 & 517 \\
Jinotega & 38 & 541 & 1,168 & 1,031 & 1,012 & 1,098 & 855 \\
Madriz & - & 63 & 209 & 260 & 199 & 156 & 129 \\
Managua & - & 2 & 3 & 2 & - & - & - \\
Matagalpa & 180 & 854 & 2,613 & 1,392 & 1,139 & 1,124 & 1,171 \\
N. Segovia & - & 231 & 219 & 172 & 145 & 368 & 364 \\
RAAN & - & 60 & 473 & 313 & 47 & 74 & 241 \\
RAAS & - & 46 & 73 & 35 & 79 & 80 & 51 \\
Rivas & - & 101 & 90 & 97 & 171 & 151 & 137 \\
Rio S.Juan & - & - & - & - & - & 188 & 224 \\
\hline Total & 505 & 2,508 & 5,639 & 4,276 & 3,551 & 4,254 & 3,743 \\
\hline
\end{tabular}

Source: CRS data base modified by authors

Some individuals were already registered in 2006 before the project intervention started. This is why there are some records from the earlier years in the data collected by CRS.

Table 6.4. Number of project participants by commodity: 2006-2012

\begin{tabular}{lccccccc}
\hline Year/Crop & 2006 & 2007 & 2008 & 2009 & 2010 & 2011 & 2012 \\
\hline Cacao & 0 & 20 & 200 & 334 & 33 & 330 & 356 \\
Coffee & 10 & 357 & 1,398 & 1,520 & 1,401 & 1,659 & 1,522 \\
Beans & 357 & 1,155 & 3,213 & 1,556 & 1,086 & 1,572 & 1,366 \\
Vegetables & 130 & 567 & 589 & 736 & 721 & 743 & 474 \\
Fruits & 32 & 82 & 57 & 94 & 142 & 130 & 81 \\
R\&T & 35 & 577 & 730 & 468 & 431 & 375 & 180 \\
\hline Total $^{15}$ & 564 & 2,758 & 6,187 & 4,708 & 3,814 & 4,809 & 3,979 \\
\hline
\end{tabular}

Source: CRS data base modified by authors

${ }^{15}$ Due to the duplication in counting, the total number of participants in Table 6.3 and Table 6.4 differ. 
The project worked with producers of cacao, coffee, beans, vegetables, fruits, and roots and tubers. Table 6.4 shows that many of them were engaged in production and sales of coffee and beans.

Among the producers, approximately $10 \%$ sold more than one commodity in a given year (Table 6.5). For instance, in 2007, 309 farmers out of 2,508 producers harvested and sold more than one commodity. The available data provide information solely about sales. Therefore, we are not able to assess how many farmers have diversified production system but sold only one crop.

Table 6.5. Number of project participants who sold more than one crop: 2006-2012

\begin{tabular}{cccc}
\hline Year & $\begin{array}{c}\text { \# of farmers who sold } \\
\text { more than one crop }\end{array}$ & $\begin{array}{c}\text { Total \# of } \\
\text { participants }\end{array}$ & $\begin{array}{c}\text { \% of farmers who sold } \\
\text { more than one crop }\end{array}$ \\
\hline 2006 & 62 & 505 & 12.3 \\
2007 & 309 & 2,508 & 12.3 \\
2008 & 553 & 5,639 & 9.8 \\
2009 & 419 & 4,276 & 9.8 \\
2010 & 339 & 3,551 & 9.5 \\
2011 & 498 & 4,254 & 11.7 \\
2012 & 317 & 3,743 & 8.5 \\
\hline
\end{tabular}

Source: CRS data base modified by authors

In addition, Table 6.6 shows how many farmers in each commodity chain sold how many crops in total. For example, out of 1,269 farmers who sold cacao in the five-year period, 1,126 sold only cacao, 139 sold cacao and one other crop, 3 sold cacao in addition to two other crops, and so on. From the table, we can see that bean, vegetables, and roots \& tubers farmers sold multiple crops yet most farmers sold only one other crop.

Table 6.6. Number of the project participants by the number of crops they produced

\begin{tabular}{lcccccc}
\hline \# of crops & Cacao & Coffee & Beans & Veg & Fruits & R \& T \\
\hline 1 & 1,126 & 7,160 & 8,287 & 2,327 & 282 & 1,841 \\
2 & 139 & 579 & 1,709 & 1,214 & 198 & 741 \\
3 & 3 & 52 & 186 & 163 & 70 & 111 \\
4 & 1 & 11 & 12 & 11 & 4 & 9 \\
\hline Total & 1,269 & 7,802 & 10,194 & 3,715 & 554 & 2,702 \\
\hline
\end{tabular}

Source: CRS data base modified by authors

In order to show the size distribution, we divide all producers in four categories. Farmers belong to the Size 1, 2, 3, and 4 groups if they possess less than 0.5ha, between 0.5 ha and 1 ha, between 1ha and 2ha, and more than 2ha of land, respectively. Landholdings are calculated based on the area that producers utilized for the production of goods sold in a given year. In other words, we only count areas that were put into production and therefore, we do not know the total land area that is owned by each producer. The details of the data set will be explained in Section 6.1.6. Table 6.7 shows how many farmers belong to which size categories in a given year. We also 
present mean, standard deviation, minimum and maximum values. As seen in the maximum values in the table, there are some producers with relatively large land areas. Those tend to possess orchards to produce fruits, which generally take up a larger space. On average, approximately $64 \%$ of the farmers in the sample own less than 1 ha of land under production.

Table 6.7. Producers divided by size categories (ha): 2006-2012

\begin{tabular}{|c|c|c|c|c|c|c|}
\hline Year & Size & $\mathrm{n}$ & Mean & s.d. & Min & Max \\
\hline \multirow{4}{*}{2006} & Size1 & 234 & 0.18 & 0.12 & 0.00 & 0.38 \\
\hline & Size2 & 168 & 0.63 & 0.14 & 0.39 & 0.99 \\
\hline & Size3 & 64 & 1.26 & 0.24 & 1.01 & 1.85 \\
\hline & Size4 & 39 & 3.45 & 2.14 & 2.01 & 11.97 \\
\hline \multirow{4}{*}{2007} & Size1 & 936 & 0.15 & 0.13 & 0.00 & 0.38 \\
\hline & Size2 & 794 & 0.67 & 0.14 & 0.39 & 0.99 \\
\hline & Size3 & 505 & 1.36 & 0.23 & 1.00 & 1.97 \\
\hline & Size4 & 273 & 3.49 & 2.52 & 2.00 & 24.64 \\
\hline \multirow{4}{*}{2008} & Size1 & 1,370 & 0.18 & 0.13 & 0.00 & 0.38 \\
\hline & Size2 & 2,012 & 0.69 & 0.12 & 0.38 & 1.00 \\
\hline & Size3 & 1,402 & 1.38 & 0.23 & 1.00 & 1.98 \\
\hline & Size4 & 855 & 3.50 & 2.59 & 2.01 & 35.20 \\
\hline \multirow{4}{*}{2009} & Size1 & 1,038 & 0.21 & 0.12 & 0.00 & 0.38 \\
\hline & Size2 & 1,437 & 0.68 & 0.13 & 0.39 & 1.00 \\
\hline & Size3 & 1,083 & 1.36 & 0.24 & 1.00 & 1.98 \\
\hline & Size4 & 718 & 3.62 & 2.59 & 2.01 & 36.61 \\
\hline \multirow{4}{*}{2010} & Size1 & 1,236 & 0.21 & 0.12 & 0.00 & 0.38 \\
\hline & Size2 & 1,048 & 0.66 & 0.14 & 0.39 & 1.00 \\
\hline & Size3 & 757 & 1.34 & 0.25 & 1.01 & 1.98 \\
\hline & Size4 & 510 & 3.45 & 2.25 & 2.01 & 21.30 \\
\hline \multirow{4}{*}{2011} & Size1 & 1,196 & 0.21 & 0.11 & 0.00 & 0.38 \\
\hline & Size2 & 1,437 & 0.67 & 0.13 & 0.39 & 1.00 \\
\hline & Size3 & 967 & 1.37 & 0.24 & 1.00 & 2.00 \\
\hline & Size4 & 654 & 3.26 & 1.84 & 2.01 & 17.60 \\
\hline \multirow{4}{*}{2012} & Size1 & 987 & 0.21 & 0.12 & 0.00 & 0.38 \\
\hline & Size2 & 1,106 & 0.68 & 0.11 & 0.39 & 1.00 \\
\hline & Size3 & 1,006 & 1.36 & 0.24 & 1.01 & 2.00 \\
\hline & Size4 & 644 & 3.09 & 1.58 & 2.01 & 21.12 \\
\hline
\end{tabular}

Size 1: less than 0.5ha

Size 2: between 0.5 ha and 1 ha

Size 3: between 1ha and 2ha

Size 4: more than 2ha

Source: CRS data base modified by authors

FAO and National Institute of Development Information (INIDE, Spanish acronym) indicate that approximately $33 \%$ of all Nicaraguan farmers possess less than 1.8ha of cultivated land at the national level (Table 6.8). This observation shows that the project worked predominantly with those who possess small land area for agricultural production. 
Table 6.8. Landholdings in Nicaragua: 2010

\begin{tabular}{lccc}
\hline Area size (ha) & Number & $\%$ & Area \\
\hline$<0.4$ & 31,758 & 12.15 & $5,131.63$ \\
$0.4-0.7$ & 16,660 & 6.38 & $10,358.98$ \\
$0.7-1.8$ & 38,149 & 14.60 & $47,694.81$ \\
$1.8-3.5$ & 35,580 & 13.62 & $94,591.07$ \\
$3.5-7$ & 33,591 & 12.85 & $178,225.78$ \\
$7-14$ & 29,775 & 11.39 & $313,725.32$ \\
$14-35$ & 37,246 & 14.25 & $891,076.89$ \\
$35-70$ & 21,074 & 8.06 & $1,085,292.86$ \\
$70-140$ & 10,768 & 4.12 & $1,091,202.35$ \\
$140-350$ & 5,318 & 2.04 & $1,170,229.34$ \\
$350<$ & 1,402 & 0.54 & $1,158,751.67$ \\
\hline Total & 261,321 & & $6,046,280.70$ \\
\hline
\end{tabular}

Source: (INIDE, 2011)

\subsubsection{The interventions}

The intervention took place through farmer cooperatives in local communities, and the NGO provided participants with technical assistance, physical assets, and capacity building in establishing business relationships with buyers of the agricultural commodities.

Table 6.9. Number of the project participants by capacity building activity: 2006-2012

\begin{tabular}{lccccccc}
\hline Year/Activity & 2007 & 2008 & 2009 & 2010 & 2011 & 2012 & Total \\
\hline $\begin{array}{l}\text { Production-related } \\
\text { Agricultural Practices }\end{array}$ & 0 & 2 & 8 & 175 & 257 & 117 & 559 \\
Agricultural Production & 562 & 1,941 & 823 & 1,169 & 492 & 267 & 5,254 \\
\hline Environment-related & & & & & & & \\
Water & 0 & 0 & 1529 & 574 & 573 & 47 & 2,723 \\
Environmental Manag. & 0 & 21 & 0 & 227 & 398 & 22 & 668 \\
\hline Gender & 0 & 140 & 11 & 365 & 227 & 128 & 871 \\
\hline Processing-related & & & & & & & \\
Manufact. Practices & 0 & 0 & 3 & 6 & 0 & 0 & 9 \\
Post-Harvest & 0 & 0 & 0 & 241 & 360 & 326 & 927 \\
\hline Market linkage-related & & & & & & & \\
Entrepren. Practices & 247 & 633 & 497 & 451 & 543 & 236 & 2,607 \\
Municipality Engag. & 0 & 288 & 133 & 222 & 286 & 381 & 1,310 \\
\hline Total & 1,056 & 3,967 & 5,166 & 5,151 & 5,296 & 2,536 & \\
\hline Source: CRS data base
\end{tabular}

Source: CRS data base modified by authors

Based on the content, we divided all intervention activities in five categories: production-, environment-, gender-, processing-, and market linkage-related activities. Table 6.9 shows the number of producers who received each capacity building in a given year. Since the intervention was initiated in September of 2007, there was no activity conducted in 2006. From the 58 | P a g e 
observations, we can see that the project focused particularly on production-related field and market linkage program. Improvement of access to safe water sources was also given a higher weight than other activities.

The content of the interventions covered a wide range of topics. The intervention team trained individual producers to participate in the Good Agricultural Practices (GAP) and other certification programs. At the same time, investments were made to improve access to water supply for agricultural usage such as irrigation as well as domestic needs (e.g. drinking water). Individual cooperatives were also given opportunities to receive training on how to maintain successful business practices as rural enterprises. Project staffs have worked closely with cooperatives to establish business relationships with buyers and exporters to market products. Issues concerning gender equality were also integrated in intervention policies and objectives by actively encouraging women's participation in the organizational structure.

Capacity buildings were implemented as workshops, field days, excursions, and lectures. For information exchange, some activities were conducted through participating in national as well as international trade and business fairs and conferences. A complete list of activities is found in Section 6.2.

The project is unique in that it intended to train farmer cooperatives as business enterprises. Reflecting this policy, the project offered opportunities for farmers and their organizations to learn about successful organizational structure that enables expansion of the institutions as economic entities. We can observe this through market linkage-related activities such as workshops on organizational structure, adequate accounting, establishing and sustaining partnerships in commercialization, and development of groups based on cooperative identity. In addition, the project initiated communication between farmer enterprises and local governments so that local governments can assist development of value chains. This can be done through negotiating the spending of municipality budget on building roads and improving other infrastructure.

The determination of what interventions are to be undertaken in which communities and/or cooperatives was done both according to the centralized project's planning and individual consortium member's wishes. Activities were first roughly designed by the operating NGO. After that, consortium members nominated particular activities to be implemented based on evaluation at the community level (Herrera Mora, 2014).

\subsubsection{Market linkage and its structure}

After harvesting crops, the project's participants sold products to a number of buyers. There were 149 different buyers and markets recorded in the data set. We categorized them in five groups: farmer organization, intermediary, local market, private company, private-export company. Out of the 149 buyers and markets, 58 are local, mostly wholesales, markets, 40 are farmer organizations, 28 are private-export companies, 13 are private companies, and the remaining 10 are intermediaries (Table 6.10). We classify small local supermarkets as local markets since it offers identical economic transactions to spot markets such as local wholesales 
markets. Private companies, both non-export and export, include some large international retail companies such as Walmart and Ritter Sport.

Table 6.10. Type of buyers

\begin{tabular}{|c|c|}
\hline Buyer type & $\mathbf{N}$ \\
\hline Farmer organization & 40 \\
\hline Intermediary & 10 \\
\hline Local market & 58 \\
\hline Private company & 13 \\
\hline Private-export company & 28 \\
\hline
\end{tabular}

Table 6.11 shows the number of observations where farmers sold their products to specific buyers in a given year. The choice of product destination largely differs across commodities. Generally speaking, export-oriented crops such as coffee, cacao and roots and tubers are sold directly to private companies more often than beans, vegetables, and fruits.

According to the information given by CRS (Palma Munguia, 2014), some buyers had agreements with cooperatives in order to secure product supply. In some cases, companies provided financial support to cooperatives by helping storage of the final products, indicating a closer relationship between the two parties than spot-market transactions. On the contrary, the majority of beans, vegetables and fruits, and roots and tubers were sold at local markets. CRS indicates that, in the case of beans and roots and tubers, products sold to intermediaries are further transferred to companies that export these products. However, in most cases, individual farmers and even farmer organizations were not able to establish direct contracts with retail companies. It was because the production was done at a relatively smaller scale and retail companies were not willing to work with small individual producers and their organizations. In addition, cooperatives were not able to facilitate access to credits in order for producers to make investment and increase production volumes.

\subsubsection{Recorded information}

Descriptive statistics presented so far are based on the record tracked by the NGO for the five years. All data are divided into three parts: basic beneficiary information, capacity building records, and sales activities.

Beneficiary information includes the following: gender, education level, cooperative they belong to, status of being a household head, leadership status in cooperatives, status of participating in the project in the final stage, location (department, municipality, and village), consortium they belong to, and sub-consortium they belong to.

Capacity building activities are recorded through the following variables: date of capacity building, content of capacity building, details of capacity building, type of capacity building (e.g. workshop, field trials), duration, total cost, cost covered by the USAID, cost covered by consortiums, cost covered by producers, location of the activities, and facilitating organization. 
If a producer received more than one activity in a given year, s/he has the corresponding number of observations for the particular year.

Table 6.11. Product destination by commodities: 2006-2012

\begin{tabular}{|c|c|c|c|c|c|c|c|}
\hline Year & 2006 & 2007 & 2008 & 2009 & 2010 & 2011 & 2012 \\
\hline \multicolumn{8}{|l|}{ Cacao } \\
\hline \multicolumn{8}{|l|}{ Farmer organization } \\
\hline \multicolumn{8}{|l|}{ Intermediary } \\
\hline Local market & & & 142 & 182 & 36 & 271 & 143 \\
\hline \multicolumn{8}{|l|}{ Private company } \\
\hline Private-export company & & 20 & 163 & 371 & 70 & 274 & 226 \\
\hline \multicolumn{8}{|l|}{ Coffee } \\
\hline Farmer organization & & 50 & 52 & 187 & 69 & 531 & 1,115 \\
\hline \multicolumn{8}{|l|}{ Intermediary } \\
\hline Local market & 10 & 177 & 944 & 747 & 854 & 1,272 & 1,279 \\
\hline Private company & & & & 2 & & & 75 \\
\hline Private-export company & & 157 & 1,194 & 1,504 & 1,326 & 1,379 & 1,003 \\
\hline \multicolumn{8}{|l|}{ Beans } \\
\hline Farmer organization & & & 34 & & & & \\
\hline Intermediary & & & 590 & & & & \\
\hline Local market & 518 & 2,144 & 2,827 & 1,695 & 1,862 & 2,121 & 1,415 \\
\hline Private company & & & 462 & 11 & & & \\
\hline Private-export company & 10 & 53 & & 21 & 181 & 19 & \\
\hline \multicolumn{8}{|l|}{ Vegetables and fruits } \\
\hline Farmer organization & & 1 & & & & 36 & \\
\hline Intermediary & 1 & 10 & & & 2 & & \\
\hline Local market & 207 & 1,573 & 3,096 & 4,198 & 4,735 & 4,860 & 2,757 \\
\hline Private company & 47 & 231 & 321 & 59 & 32 & 47 & 7 \\
\hline Private-export company & & 22 & 149 & 100 & 28 & 47 & 11 \\
\hline \multicolumn{8}{|l|}{ Roots and tubers } \\
\hline Farmer organization & & 2 & 210 & 116 & & 13 & \\
\hline Intermediary & & & 3 & & & & \\
\hline Local market & 48 & 518 & 828 & 1,948 & 1,012 & 886 & 449 \\
\hline Private company & 8 & 22 & & 4 & 1 & & \\
\hline Private-export company & & 341 & 2,157 & 1,296 & 819 & 114 & 1,024 \\
\hline
\end{tabular}

Source: CRS data base modified by authors

Finally, sales activities are reported by: date of sales, type of crops sold, type of crop category sold, product quality, type of production practices used (e.g. organic, certified organic), type of production technology (e.g. traditional, advanced), area in $\mathrm{Mz}$ that corresponds to the quantity of products being sold, quantity, unit, price sold in Nicaraguan Córdobas, type of market (e.g. national, international, regional), type of buyers, country of product destination, labor cost measured in days, total production cost, and exchange rate between US dollars and Nicaraguan Córdobas.

Table 6.12 shows an example of the original data set. First, land area owned and used by each producer was recorded based on the area corresponding to each sales volume. For instance, Producer A sold 12qq of Product 1 in March of 2008. It was produced in a one-Mz area and cost 
25USD. Producer A received 40USD per unit of sales. The production cost and area reported correspond only to this specific economic transaction. As a result, the second transaction of the year 2008, even though Producer A produced and sold the same product, Product 1, shows different figures. Based on the two observations, we calculate annual cost, annual area, and annual price (Columns (h), (i), and (j)). These three values are for the particular product that we are concerned with at a moment. Therefore, we apply the same procedure separately for Product 1 and Product 2. Annual cost is a simple sum of both production costs from Column (d) while annual area and price are the sum of observations from Columns (e) and (g) divided by the number of observations (in this case, two). The same procedure is applied for Product 2 in the year 2008. At the end, we obtain total cost and total area (Columns (k) and (l)) for Farmer A in the year 2008.

Table 6.12. Example of available data

\begin{tabular}{llcccccccccc}
\hline (a) & (b) & $(\mathrm{c})$ & $(\mathrm{d})$ & $(\mathrm{e})$ & $(\mathrm{f})$ & $(\mathrm{g})$ & $(\mathrm{h})$ & $(\mathrm{i})$ & $(\mathrm{j})$ & $(\mathrm{k})$ & $(\mathrm{l})$ \\
\hline ID & $\begin{array}{c}\text { Date } \\
\text { sold }\end{array}$ & Crop & $\begin{array}{c}\text { Production } \\
\text { cost } \\
(\mathrm{USD} / \mathrm{Mz})\end{array}$ & $\begin{array}{c}\text { Area } \\
(\mathrm{Mz})\end{array}$ & $\begin{array}{c}\text { Quantity } \\
(\mathrm{qq}) \\
\text { produced }\end{array}$ & $\begin{array}{c}\text { Price } \\
\text { received } \\
(\mathrm{USD})\end{array}$ & $\begin{array}{c}\text { Cost/ } \\
\text { year }\end{array}$ & $\begin{array}{c}\text { Area/ } \\
\text { year }\end{array}$ & $\begin{array}{c}\text { Price/ } \\
\text { year }\end{array}$ & $\begin{array}{c}\text { Total } \\
\text { cost }\end{array}$ & $\begin{array}{c}\text { Total } \\
\text { area }\end{array}$ \\
\hline A & Mar-08 & 1 & 25 & 1 & 12 & 40 & 75 & 1.5 & 40 & 215 & 2.5 \\
A & Sep-08 & 1 & 50 & 2 & 25 & 40 & 75 & 1.5 & 40 & 215 & 2.5 \\
A & Oct-08 & 2 & 140 & 1 & 700 & 11 & 140 & 1 & 11 & 215 & 2.5 \\
A & May-09 & 2 & 130 & 0.8 & 500 & 13 & 130 & 0.8 & 13 & 205 & 2.8 \\
A & May-09 & 1 & 75 & 2 & 40 & 30 & 75 & 2 & 30 & 205 & 2.8 \\
\hline B & Apr-07 & 1 & 12 & 1 & 20 & 18 & 12 & 1 & 18 & 77 & 4 \\
B & Apr-07 & 3 & 65 & 3 & 5 & 350 & 65 & 3 & 350 & 77 & 4 \\
B & May-08 & 1 & 12 & 1 & 5 & 22 & 12 & 1 & 22 & 12 & 1 \\
B & Mar-10 & 3 & 60 & 3 & 5 & 520 & 145 & 3 & 535 & 342 & 10 \\
B & May-10 & 1 & 13 & 2 & 7 & 20 & 26 & 2 & 25 & 342 & 10 \\
B & Sep-10 & 1 & 13 & 2 & 7 & 30 & 26 & 2 & 25 & 342 & 10 \\
B & Oct-10 & 3 & 85 & 3 & 10 & 550 & 145 & 3 & 535 & 342 & 10 \\
\hline
\end{tabular}

Source: Authors

Second, some participants were involved in sales of multiple crops. Therefore, we find same individuals across different commodity chains in a year. For instance, Producer B sold Product 1 and 3 in the year 2007. S/he sold only Product 1 in 2008 but both products in 2010. In other words, we do not observe the same producers in the same commodity chains every year.

Third, when producers did not sell any products in a given year, they appear as missing observations in terms of all production variables in the data set. For example, Producer B did not sell any products in 2009. Therefore, the information is missing for this particular year. In addition, s/he was less active during 2008. As a result, it seems that Producer B significantly reduced his/her land area, which is not necessarily true in reality.

These observations highlight that our data set is directly linked to sales activities. In other words, we are not able to understand how much total land each farmer owns or possesses. Put it in another perspective, we have the access to information in much detail, such as quality, quantity, prices and buyers of products for a specific economic transaction. 


\subsection{Detailed list of intervention activities}

\subsubsection{Market Linkage Program}

\section{Entrepreneurial practices}

SISTEMAS CONTABLES

TALLER DEL PLAN DE DESARROLLO

21 FERIA ANUAL SCAA 2009

ACTIVIDAD DE MERCADEO

ACTUALIZACIÓN DE LOS REGISTROS CONTABLES Y DE CARTERA.

ADMINISTRACIÓN

ADMINISTRACION DE NEGOCIOS

ADMINISTRACIÓN DE EMPRESAS ASOCIATIVAS RURALES

ADMINISTRACIÓN DE EMPRESAS ASOCIATIVAS RURALES.

ADMINISTRACIÓN DE FONDOS REVOLVENTES

ADMINISTRACIÓN DE NEGOCIOS: GRUPO COMIDER

ADMINISTRACIÓN DE NEGOCIOS: GRUPO COMIDER

ADMINISTRACIÓN DE PEQUENOS NEGOCIOS

ADMINISTRACIÓN Y CONTROLES BÁSICOS CONTABLES

ADMON DE CREDITO

AGRO- NEGOCIO

AGROPROCESAMIENTO DE PRODUCTOS

ALIANZA DE APRENDIZAJE

ALIANZA DE APRENDIZAJE (ADA)

ALIANZAS DE APRENDIZAJE

ALIANZAS DE APRENDIZAJE CON ENFOQUE DE CADENAS DE VALOR

ALIANZAS PARA EL APRENDIZAJE

ANÁLISIS DE ESTADOS FINANCIEROS

ANÁLISIS DE RAZONES Y RENTABILIDAD FINANCIERA

ANÁLISIS DEL MODELO DE NEGOCIO DE COOPERATIVA APODER.

ANÁLISIS FINANCIERO

ANALISIS FINANCIERO DE LAS EMPRESAS ASOCIATIVAS RURALES

ANIVERSARIO DEL TLC CAFTA CON PROFCAFTA.

APLICACIÓN DE HERRAMIENTA ADA Y PRESENTACIÓN DE PLAN ESTRATEGICO

APLICACIÓN DE LAS RAZONES FINANCIERAS A LOS ESTADOS FINANCIEROS

APROBACION DEL REGLAMENTO DEL ESTATUTO DE CECOSEMAC

ASAMBLEA DE DELEGADO

ASAMBLEA GENERAL EXTRAORDINARIA

ASESORIA CONTABLE

ASESORIA LEGAL PARA FONDOS REVOLTES

ASESORIA PARA MANEJO DE FONDOS REVOLVENTES

ASPECTO DE COMERCIALIZACIÓN DE RAIICES Y TUBÉRCULOS CON EMPRESA DAISA

AUTO EVALUACIÓN ADA

AUTO EVALUACIÓN FACILITADA

AUTOEVALUACIÓN CON HERRAMIENTA ADA

AUTOEVALUACIÓN CON HERRAMIENTA ADA EVALUACION INTERMEDIA

AUTOEVALUACIÓN DE COMULSAN CON HERRAMIENTA ADA

AUTO-EVALUACIÓN DEL PROCESO DE CERTIFICACIÓN CON RAINFOREST ALLIANCE

AUTOEVALUACION FACILITADA ADA

AUTOEVALUACIÓN PARA LA GESTIÓN DE EMPRESA

B.P.A

BASE LEGAL DE COOPERATIVA

BASE LEGAL DE LA COOPERATIVA (ÓRGANOS DE DIRECCIÓN)

BASE LEGAL DE LAS COOPERATIVAS BASADA EN LA LEY \# 499 (ORGANOS DE DIRECCIÓN)

BENEFICIADO HUMEDO

BENEFICIADO HUMEDO ECOLOGICO

BUENAS PRACTICAS EMPRESARIALES A EMPRESAS RURALES EN FINANZAS Y ADMON

CADENA DE VALOR R\&T

CADENAS DE VALOR

CAPACITACION COOPERATIVISMO

CAPACITACION DE GRUPOS GIAR

CAPACITACION EN LEY DE COOPERATIVISMO

CAPACITACION GIAR

CAPACITACIÓN PARA PREPARACION PARA LA TAZA DE LA EXCELENCIA

CAPACITACIÓN SOBRE CONTABILIDAD; METODOLOGÍA LAS LAVES PARA EL ÉXITO FINANCIERO

CAPACITACIÓN SOBRE COOPERATIVISMO A 36 SOCIOS COOPANG.

CATACION DE CAFÉ

CHARLA SOBRE ELABORACIÓN DE PRESUPUESTOS

CIERRE DE OPERACIONES 
COMISION TERRITORIAL DE CACAO

COMO REALIZAR ASAMBLEA GENERAL DE SOCIOS Y PROCEDIMIENTOS PARA ELEGIR NUEVOS DIRECTIVOS CONCEPTOS BÁSICOS DE ADMINISTRACIÓN DE EMPRESAS ASOCIATIVAS.

CONCEPTOS BASICOS DE MERCADEO

CONCEPTOS BÁSICOS SOBRE ADMINISTRACIÓN DE EMPRESAS ASOCIATIVAS RURALES

CONCEPTOS BÁSICOS SOBRE CONTABILIDAD.

CONCEPTOS SOBRE CRÉDITO RURAL

CONCEPTOS SOBRE CRÉDITO Y ADMINISTRACIÓN DE EMPRESAS ASOCIATIVAS RURALES

CONDUCCIÓN DE REUNIONES Y PREASAMBLEAS DEL COMITÉ ALDEA

CONFERENCIA FERIA SCAA VIDA VERDE

CONGRESO CA DE CIENCIA Y TECNOLOGIA Y ALIMENTO

CONSTITUCION CENTRAL DE COOPERATIVAS

CONTABILIDAD

CONTABILIDAD BASICA

CONTABILIDAD BÁSICA

CONTABILIDAD DE CRÉDITO

CONTABILIDAD Y CARTERA

CONTABILIDAD Y CARTERA CON DIRECTIVOS DE ORGANOS DE GESTIÓN

CONTROL DE PLAGAS EN FRUTALES

CONTROL DE PLAGAS EN PLATANO

CONTROL DEL FONDO DE EFECTIVO

CONTROL INTERNO INFORME COSO

CONTROL Y MANEJO BODEGA

CONTROL Y MANEJO DE CRÉDITOS

COOPERARTIVISMO 40 HORAS

COOPERATIVISMO

COOPERATIVISMO Y GÉNERO

COOPERATIVISMO/CERTIFICACION/COSTOS DE PRODUCCION

CURSO INTERNACIONAL "FORMACIÓN DE CATADORES DE CACAO".

CURSO WORKSHOP INTERNACIONAL DE CATACIÓN DE CACAO Y CHOCOLATE

DEFINICIÓN DEL MODELO DE NEGOCIO DE COOPERATIVA APODER.

DESARROLLO DE CAPACIDADES EN LA FIJACION DE PRECIOS, NEGOCIACION DE CONTRATOS COMERCIALES DESARROLLO DE MODULO 3 ADA

DESARROLLO EMPRESARIAL

DESARROLLO EMPRESARIAL

DESARROLLO EMPRESARIAL / COMERCIALIZACIÓN

DESARROLLO EMPRESARIAL A APROBACION DE POLITICA DE ACOPIO DE CECOSEMAC

DESARROLLO EMPRESARIAL Y GENERO A MUJERES

DESARROLLO ORGANIZACIONAL

DESARROLLO Y ADMISTRACIÓN EMPRESARIAL

DESARROLLO Y ADMON EMPRESARIAL

DEVOLUCIÓN DE RESULTADOS DE CATACIÓN

DIAGNOSTICO COOSMPROJIN R.L - INDE - PROSEDE

DIAGNOSTICO DE HERRAMIENTA ADA, EVALUACIÓN INTERMEDIA PARA COOPANG

DIAGNOSTICO DE HERRAMIENTA ADA, EVALUACIÓN INTERMEDIA PARA COOPEMET

DIAGNOSTICO DE LA COOPERATIVA

DIAGNÓSTICO EVALUACIÓN INTERMEDIA ALIANZA PARA APRENDIZAJE (ADA)

DIÁLOGO CON EL SECTOR CACAO PARA EL DASARROLLO SOSTENIBLE DE LA PRODUCCIÓN DE CACAO FINO.

DISEÑO Y ELABORACIÓN DEL PLAN DE AUTOSUFICIENCIA

DISEÑO Y PREPARACIÓN DE UN PLAN PARA COOPERATIVAS PARA LOGRAR LA AUTO SOSTENIBILIDAD.

DIVERSIFACIÓN, VISIÓN EMPRESARIAL Y MICRO EMPRESA

DIVULGACION DE MATERIAL PARA ACCESO A SERVICIOS FINANCIEROS Y BANACARIOS DIRIGIDO A

COOPERATIVAS

EDUCACIÓN COOPERATIVISMO

ELABORACIÓN DE PLAN DE ACCIÓN

ELABORACIÓN DE PLAN DE AUTOSUFICIENCIA CON COOPERATIVA APODER.

ELABORACION DE PLAN DE AUTOSUFICIENCIA COOPERATIVA EL CHIMBORAZO

ELABORACIÓN DE PLAN DE AUTOSUFICIENCIA DE COOPERATIVA ECOLÓGICA 15 DE MAYO.

ELABORACIÓN DE PLAN DE AUTOSUFICIENCIA DE COOPERATIVA NUEVO AMANECER.

ELABORACIÓN DE PLAN DE AUTOSUFICIENCIA DE COOPERTATIVA CON SOCIOS Y DIRECTIVOS DE COOPERATIVA APODER.

ELABORACION DE PLAN DE NEGOCIOS DE LA COOPERATIVA

ELABORACIÓN DE PLAN ESTRATÉGICO

ELABORACIÓN DE PLANES DE NEGOCIO DEL COLECTIVO DE MUJERES DE LA COOPERATIVA APODER

ELABORACION DE PLANES DE NEGOCIOS

ELABORACIÓN DE PLANES DE NEGOCIOS

ELABORACION DE PLANES DE NEGOCIOS PARA COOPERATIVAS

ELABORACION DE PLANES PARA MEJORAMIENTO DE CARTERA Y CARTERA Y RECEPCION DE CREDITOS

ELABORACION DE POAS DE COOPERATIVAS

ELABORACIÓN DE UN PLAN DE ACCIÓN DE LAS COOPERATIVAS

ELABORACIÓN PLAN AUTOSUFICIENCIA COOPERATIVA NUEVO AMANECER 
ELABORACIÓN PLAN DE AUTOSUFICIENCIA COOPERATIVA ECOLÓGICA 15 DE MAYO.

ELABORACIÓN PLAN DE AUTOSUFICIENCIA DE COOPERATIVA APODER.

ELABORACIÓN PLAN DE AUTOSUFICIENCIA DE COOPERATIVA ECOLÓGICA 15 DE MAYO

ELABORACIÓN PLAN DE DESARROLLO

EMPRESAS ASOCIATIVAS

ENTRENAMIENTO ESTRUCTURA COOPERATIVA

ESTRATEGIA DE MERCADOS LOCALES

ESTRATEGIAS DE COMERCIALIZACIÓN

ESTRATEGIAS DE COMERCIALIZACIÓN COLECTIVA

ESTRATEGIAS DE COMERCIALIZACIÓN DE FRIJOL

ESTRATEGIAS DE COMERCIALIZACIÓN MALANGA

ESTRETAGIAS EMPRESARIAL CON CONSEJO Y GERENCIA DE LAS COOP.

ESTRUCTURA Y FUNCIONAMIENTO C. CRÉDITO

ESTUDIO DE ESTATUTOS CECOOPSEMEIN

ESTUDIO DE MANUALES,FUNCIONES ADMINISTRATIVAS Y CONTROL INTERNO

ESTUDIO DE POLITICAS Y PROCEDIMIENTOS DE CREDITO

EVALUACION INTERMEDIA DE ADA

EVALUACION Y PLANIFICACION DE TRAZABILIDAD DEL RUBRO CAFÉ

EVALUACIÓN Y SEGUIMIENTO AL POA COOP DALIA Y ECOLÓGICA

EXPO FERIA TECNOLOGICA IMNOVADORA MATERIAL GENETICO Y ALIMENTOS TRADICIONALES

EXPO FERIA TECNOLOGICA INNOVADORA MATERIAL GENETICO Y ALIMENTOS TRADICIONALES

EXPOAPEN

EXPOSICIÓN DE APENN

FACILITACION DE EVENTOS EDUCATIVOS

FACILITACION MODULO NO 2 "FORTALECIMIENTO DE PROCESOS ORGANIZATIVOS", PARTE 1

FACILITACION MODULO NO 2 "FORTALECIMIENTO DE PROCESOS ORGANIZATIVOS", PARTE 2

FERIA ANUAL SCAA EN PORTLAND-OREGON - USA

FERIA DE SEGURIDAD ALIMENTARIA "FAO"

FERIA DEL APRENDIZAJE DE LA ADA

FERIA DEL V ANIVERSARIO DEL CAFTA

FERIA EXPO APEN

FERIA EXPO APEN

FERIA EXPOAPEN

FERIA FAO

FERIA PROCAFTA

FERIA SCAA

FERIA TECNOLOGICA DE MAIZ Y FRIJOL

FILOSOFIA ADMINISTRATIVA Y LEGISLACION COOPERATIVA A NUEVOS ASOCIADOS DE ECOVEGETALES

FILOSOFIA DE COOPERATIVISMO

FILOSOFIA DEL COOPERATIVISMO

FILOSOFIA DEL COOPERATIVISMO Y PROCEDIMIENTOS PRACTICOS

FILOSOFIA Y NOCIONES BASICAS DE COOPERATIVISMO

FILOSOFIA, ADMINISTRACION Y PRINCIPIOS COOPERATIVOS A NUEVOS SOCIOS

FILOSOFÍA, GESTIÓN Y LEGISLACIÓN COOPERATIVA

FINANCIAMIENTO DE PLAN DE NEGOCIO DEL CHIMBORAZO

FOLOSOFIA COOPERATIVISMO

FORMULACIÓN DE ESTRATEGIA DE LAS COOPERATIVAS A TRAVÉS DEL ANALISIS FODA.

FORO DE LA CADENA DE FRIJOL

FORTALECER CAPACIDADES EN LA POLITICA DE ACOPIO DE CECOSEMAC

FORTALECER CAPACIDADES GERENCIALES

FORTALECIMEINTO ORGANIZATIVO DEL SECTOR CACAO DE NICARAGUA

FORTALECIMIENTO A ESTRUCTURA

FORTALECIMIENTO AL PROCESO DE GRADUACIÓN DE COOPERATIVAS A.C SANDINO Y LA ESPERANZA DE

CECOCAFEN

FORTALECIMIENTO COOPERATIVA

FORTALECIMIENTO COOPERATIVO

FORTALECIMIENTO COOPERATIVO

FORTALECIMIENTO COOPERATIVO, ASAMBLEA CONSTITUTIVA Y ESTATUTOS

FORTALECIMIENTO DE CAPACIDADES COMERCIALES Y GERENCIALES

FORTALECIMIENTO DE CAPACIDADES GERENCIALES

FORTALECIMIENTO DE CAPACIDADES GERENCIALES Y ADMON

FORTALECIMIENTO DE CAPACIDADES GERENCIALES Y COMERCIALES POLITCA ACOPIO ACOPIO

CECOSEMAC

FORTALECIMIENTO DE CAPACIDADES Y ADMINISTRACION DE LAS COOPERATIVAS

FORTALECIMIENTO DE LAS EXPORTACIONES DE FRIJOL CAFTA DR

FORTALECIMIENTO DE PROCESOS ORGANIZATIVOS QUE SUSTENTAN LA GESTION DE LAS EMPRESAS

ASOCIATIVAS RURALES

FORTALECIMIENTO EMPRESARIAL

FORTALECIMIENTO EMPRESARIAL - CERTIFCADO FLO CERT

FORTALECIMIENTO INSTITUCIONAL

FUNCION DE ORGANOS DE GESTION 
FUNCION DE ORGANOS DE GESTION EN COOPERATIVA COOSEMES

FUNCION DE ORGANOS DE GESTION EN COOPERATIVA COOSENSAN

FUNCIONAMIENTO COOPERATIVO

FUNCIONES DE JUNTA DIECTIVA.

FUNCIONES DE LAS JUNTAS DIRECTIVAS

FUNCIONES DEL CONSEJO DE ADMINISTRACIÓN Y PLAN DE NEGOCIOS

FUNCIONES Y ROLES DEL AGROSERVICIO DE COOPERATIVA ECOLÓGICA 15 DE MAYO.

FUNDAMENTOS CONTABLES

GESTION COOPERATIVA EMPRESARIAL

GESTION COOPERATIVA Y GENERO

GESTIÓN ORGANIZATIVA

GESTION Y ADM COOPERATIVA

GESTION Y ADMON COOPERATIVA

GESTORES DE INNOVACIÓN DE AGROINDUSTRIA RURAL (GIAR)

GESTORES DE INNOVACIÓN DE AGROINDUSTRIA RURAL: MAPEO CADENA DE FRIJOL.

GIRA DE COMERCIALIZACIÓN A EMPRESA DAISA

GIRA DE COMERCIALIZACIÓN DE CACAO

GIRA DE INTERCAMBIO EN COMERCIALIZACION EN HORTIFRUTI

GIRA DE INTERCAMBIO EN EL AREA DE COMERCIALIZACION

GIRA DE NEGOCIOS BUSQUEDA DE MERCADOS PARA MALANGA

GIRA INTERNA A FINCA SANTA CLARA - AGROINDUSTRIA

HERRAMIENTA DE DIAGNOSTICO ADEA

HERRAMIENTA DIAGNÓSTICO DE LA COOPERATIVA

IBI IMPUESTO DE BIENES INMUEMBLES Y REGISTRO MUNICIPAL

IDENTIFICACIÓN DE LAS COOPERATIVAS Y ELABORACIÓN DEL MAPA ESTRATEGICO DE LAS

COOPERATIVAS.

IDENTIFICACION DE OPORTUNIDADES DE MERCADO

II TALLER DE FORTALECIMIENTO AL PROCESO DE GRADUACIÓN DE COOPERATIVAS A.C SANDINO Y LA

ESPERANZA DE CECOCAFEN

IMPLEMENTACIÓN DE HERRAMIENTA ADA - MÓDULO \# 2: "FORTALECIMIENTO DE LOS PROCESOS SOCIO-

ORGANIZATIVOS QUE SUSTENTAN LA GESTIÓN DE LAS EMPRESAS ASOCIATIVAS RURALES"

INDICADORES DE GESTIÓN DE LA CARTERA DE CRÉDITO

INFORMACIÓN SOBRE PUESTO DE BOLSA DE LA FISE.

INFORME DE EJECUCION PRESUPUESTARIA

INTERCAMBIO CONTROL INTERNO

INTERCAMBIO DE EXPERIENCIA CON MUJERES DE UNA COOPERATIVA DE YALI

INTERCAMBIO DE EXPERIENCIA EN EL USO Y MANEJO DE BIODIGESTORES

INTERCAMBIO DE EXPERIENCIA ENTRE LAS COOPERATIVAS COOPANG, COOPEMET Y GTG.

INTERCAMBIO DE EXPERIENCIA ENTRE MUJERES PROMOTORAS

INTERCAMBIO DE EXPERIENCIA PARA CONOCER EL FUNCIOMIENTO ORGANIZATIVO DE LA COOPERATIVA

RIOS DE AGUA VIVA.

INTERCAMBIO DE EXPERIENCIAS AGROSERVICIOS

INTERCAMBIO DE EXPERIENCIAS MODELOS DE COOPERATIVISMO

INUGURACIÓN DE PLATAFORAMA AGROINDUSTRIAL

IV FERIA CAMPESINA

LET'S COFFEE

LEY DE COOPERATIVISMO

LEY TRIBUTARIA Y CATASTRO

LIDERAZGO

LIDERAZGO EMPRESARIAL

LIDERAZGO EMPRESARIAL A LOS MIEMBROS DE LA ASAMBLEA DE CECOOPSEMEIN

LIDERAZGO ORGANIZACIONAL

LIDERAZGO-DESARROLLO EMPRESARIAL

LINEAMIENTOS EMPRESARIALES PARA LA CENTRAL DE COOPERATIVAS

LLAVES DEL EXITO FINANCIERO I

LLENADO LIBROS DE REGISTROS PARA CERTIFICACIÓN

MANEJO DE CAFÉ

MANEJO DE CRÉDITO

MANEJO DE FONDOS REVOLVENTES.

MANEJO DE LOS RECURSOS CONTABLES

MANEJO DE SOFWARE CONTABLE CONTAPYME

MANEJO Y USO DE CREDITO.

MANEJO Y USO DE MANUAL DE SERVICIOS FINANCIEROS

MANUAL DE PROCEDIMIENTO DE CREDITO

MECANISMO PARA LA COMERCIALIZACIÓN DE LA CANELA.

MECANISMOS DE COMERCIALIZACION DE FRIJOL NEGRO

MERCADEO Y CAFÉ ORGANICO FLO

MESA DEL FRIJOL

MESA NACIONAL DE CACAO, FORTALECIMEINTO ORGANIZATIVO DEL SECTOR CACAO DE NICARAGUA

DENTRO DEL MARCO ESTRATEGICO DEL PLAN DE AGROINDUSTRIA RURAL.

METEDOLOGIA PARA CAPACITACION

$66 \mid \mathrm{P}$ a g e 
METODOLOGÍA DE ELABORACIÓN DE PLANES DE ACCIÓN.

METODOLOGÍA PARA LA ELABORACIÓN DE PLANES DE ACCIÓN.

METODOLOGÍA PARA EL DISEÑO Y

FACILITACIÓN DE EVENTOS EDUCATIVOS

METODOLOGÍA PARA ELABORACIÓN DE PLANES DE ACCIÓN.

METODOLOGIAS DE PROMOTORIA

MÓDULO 3, I PARTE: ORIENTACIÓN ESTRATÉGICA CON ENFOQUE DE CADENA DE VALOR PARA EMPRESAS

ASOCIATIVAS RURALES

MODULO AGROINDUSTRIA

MODULO III DESARROLLO EMPRESARIAL PROMOTORAS DE GENERO

MÓDULO IV DE ALIANZA DE APRENDIZAJE: PLANES DE NEGOCIOS.

MONTAJE DEL SISTEMA DE CARTERA DE LAS COOPERATIVAS NUEVO AMANECER Y ECOLÒGICA 15 DE

MAYO.

MOTIVACION Y CONCIENTIZACION COOPERATIVA

NEGOCIACIONES CON PROVEEDORES TECNOLOGIAS Y LAS COOPERATIVAS.

OBLIGACIONES LEGALES DE LA COOPERATIVA

OBLIGACIONES LEGALES DE LA COOPERATIVAS CON LA D.G.I CONFORME LEY DEL I.R.

ORGANIZACIÓN COOPERATIVISMO(FUNCIONES JUNTA DE VIGILANCIA Y COMITÉS DE EDUCACIÓN)

ORGANIZACIÓN DE GRUPO DE MUJERES.

ORGANIZACIÓN Y CONDUCCIÓN DE REUNIONES Y ASAMBLEAS

ORGANIZACION Y LIDERAZGO

ORIENTACION ESTRATEGICA CON ENFOQUE DE CADENA DE VALOR PARA LA GESTION DE EMPRESAS

RURALES, SESION 1

ORIENTACION ESTRATEGICA CON ENFOQUE DE CADENA DE VALOR PARA LA GESTION DE EMPRESAS

RURALES, SESION 2

ORIENTACION ESTRATEGICA CON ENFOQUE DE CADENA DE VALOR PARA LA GESTION DE EMPRESAS

RURALES, SESION 3

PANEL DE CATACIÓN DE CACAO NICARAGÜENSE

PARTICIPACION EN EVENTO TAZA DE LA EXCELENCIA

PARTICIPACION EN FERIA

PARTICIPACION EN FERIA DE CAFESES ESPECIALES SCAA

PARTICIPACION EN FERIA GROPECUARIA FENACOOP

PARTICIPACION EN FERIA PROCAFTA

PARTICIPACIÓN EN FERIA SOBRE SEGURIDAD ALIMENTARIA Y NUTRICIONAL ORGANIZADA POR LA FAO

PASOS PARA EL MONITOREO DE LOS SISTEMAS DE CONTROL INTERNO

PLAN DE ACCION DE LA COOPERATIVA

PLAN DE ACCIÓN DE LA COOPERATIVA

PLAN DE AUTOSUFICIENCIA DE COOPERATIVA ECOLÓGICA 15 DE MAYO.

PLAN DE COMPETITIVIDAD DE CADENA DE VALOR DE FRIJOL

PLAN DE DESARROLLO

PLAN DE DESARROLLO COSAPUR

PLAN DE NEGOCIOS

PLAN DE NEGOCIOS ECOVEGETALES

PLAN ESTRATÉGICO

PLAN ESTRATEGICO CON JUNTA DIRECTVA DE COOPANG

PLANEACION ESTRATEGICA MISION Y VISION

PLANEACIÓN ESTRATÉGICA, DER

PLANES DE ACCIÓN COMUNITARIA

PLANES DE NEGOCIO

PLANES DE NEGOCIO ALIANZA DE APRENDIZAJE ADA NICARAGUA.

PLANES DE NEGOCIO COOPERATIVISMO

PLANES DE NEGOCIO PARA GESTION DE EMPRESAS ASOCIATIVAS RURALES

PLANES DE NEGOCIOS

PLANIFICACIÓN DEL ASESORAMIENTO DE ACTIVIDADES PRODUCTIVAS EN SAF CON LA RED DE

PROMOTORES.

PLANIFICACIÓN DEL ASORAMIENTO DE ACTIVIDADES PRODUCTIVAS EN SAF CON LA RED DE PROMOTORES.

PLANIFICACIÓN ESTRATEGICA COMISIÓN TERRIOTORIAL DE CACAO

PLANIFICACIÓN ESTRATEGICA PARTICIPATIVA CON COOPERATIVAS

PLANIFICACION ESTRATEGICA Y EMPRESARIAL DE LAS ORGANIZACIONES

PLANIFICACIÓN ESTRATEGICO

PLANIFICACIÓN ORGANÍCA DE FINCAS DE LA COOPERATIVA COODEPROSA

PLANIFICACIÓN PARA LA ELABORACIÓN DE PRODUCTOS DE CHOCOLATE Y PIMIENTA FERIA EXPO APEN PLANIFICACIÓN PARA MONTAJE DE SISTEMAS CONTABLES.

PLANIFICACION PARA PROCESO DE CERTIFICACION DE MERCADO JUSTO EN FRIOL FLO

PLANIFICACION Y EJECUCION DEL SISTEMA DE CONTROL INTERNO PARA CAFÉ ORGANICO Y COMERCIO

JUSTO

PLATANOS EN EL MARCO DEL CAFTA DR

POLITICAS DE CREDITO

POLITICAS DE CREDITO ECOVEGETALES

POLITICAS DE SERVICIO DE LAS COOPERATIVA

POLITICAS DE SERVICIOS DE DESARROLLO EMPRESARIAL 
POLITICAS DE SERVIVIOS DE LA COOPERATIVA COOSEMTRI

PRECENTACION DE CACAO FINO

PRECIOS DE EXPORTACIÒN DE CAFÈ

PRE-COOPERATIVISMO

PRESENTACIÓN :PROYECTO FONDO DE INNOVACIÓN DE APODER

PRESENTACIÓN :PROYECTO FONDO DE INNOVACIÓN DE CECOOP

PRESENTACIÓN :PROYECTO FONDO DE INNOVACIÓN DE PROCONTSA

PRESENTACIÓN :PROYECTO FONDO DE INNOVACIÓN DE VINICUQ

PRESENTACIÓN DE MANUALES DE CONTROL INTERNO, CRÉDITO Y FUNCIONES

PRESENTACIÓN DE PLAN ESTRATÉGICO

PRESENTACION DE PROPUESTA DE POA 2010-2011

PRESENTACION DE REVICION DE MANUALES DE FUNCIONES DE CECOOPSEMEIN A DIRECTIVOS

PRESENTACION PILOTAJE CRS WALMART, A PRODUCTORES SOCIOS DE COOSMPROJIN

PRESENTACION PLAN DE DESARROLLO COOPERATIVA COOPANG R.L

PRESENTACION PLAN DE DESARROLLO COOPERATIVA COOPEMET R.L

PRESENTACION PLAN DE DESARROLLO COOPERATIVA GTG.

PRESENTACIÓN Y REVISIÓN DE PROPUESTA DE MANUALES DE CONTROL INTERNO, CRÉDITO Y FUNCIONES PRIMER FERIA AGROPECUARIA DE OCCIDENTE PROMOVIDA POR UPANIC

PRINCIPIOS DE ADMINISTRACION

PRINCIPIOS DE LIDERAZGO

PRINCIPIOS Y VALORES DEL COOPERATIVISMO

PROCAFTA DE VEGETALES Y MINIVEGETALES

PROCESO DE EXPORTACIÓN DE CAFÉ

PROMOCIÓN DE LA RSE

PROMOCION DE VENTA DE PLANTULAS DE RAICES Y TUBERCULOS

PROMOTORIA /TALLER CON GRUPOS FOCALES CON JÓVENES PONTENCIALES PROMOTORES

PROMOVER LA INTEGRACIÓN DE LA COMISIÓN DE HORTALIZAS

PROYECTO FONDOS DE INNOVACIÓN DE INNOVACIÓN

RAZONES FINANCIERAS Y CONTROL DE BODEGA

REFLEXION ORGANIZATIVA

REFORMA DE ESTATUTOS DE COOSMESA

REGIMEN PRESUPUESTARIO

REGISTRO Y ORGANIZACIÓN DE OPERACIONES DIARIAS

REPLICA ADA (ALIANZA DE APRENDIZAJE)

REPLICA ADA MÓDULO IV "PLANES DE NEGOCIOS"

REPLICA M II COOPERATIVISMO POR PARTE DE LAS PROMOTORAS DE GENERO

REPLICA M-III DESARROLLO EMPRESARIAL POR PARTE DE LAS PROMOTORAS DE GENERO

REPLICA MODULO CUATRO ADA PLANES DE NEGOCIO

REPLICA MÓDULO II COOPERATIVISMO DE LAS PROMOTORAS

REPLICA MÓDULO III: ORIENTACIÓN ESTRATÉGICA CON ENFOQUE DE CADENA DE VALOR. ADA NICARAGUA. REUNIÓN CON CONSEJOS DE ADMINISTRACION DE LAS COOPERATIVAS

REUNIÓN COOPROCAFUC, COODEPROSA, ECOM-ATLANTIC

REUNIÓN DE JUNTAS DIRECTIVAS CON COMERCIALIZADORA DE FRIJOL

REUNIÓN DE SOSTENIBILIDAD DEL SCAA

REUNIÓN DE TRABAJO COMISIÓN TERRITORIAL DE CACAO

REUNIÓN DEL SECRETARIADO EJECUTIVO DE LA MESA NACIONAL DE CACAO.

REVISAR POLITICAS DE MANEJO DE TIENDAS DE INSUMOS

REVISION DEL REGLAMENTO INTERNO Y MANUAL DE CREDITO.

RONDA DE NEGOCIOS

RONDA DE NEGOCIOS ENTRE PROVEEDORES DE TECNOLOGÍAS Y ORGANIZACIONES DE PRODUCTORES/AS

RONDA DE NEGOCIOS: PRODUCTOS ALTERNATIVOS PARA LA PRODUCCIÓN DE GRANOS BÁSICOS Y

HORTALIZAS.

RUEDA DE NEGOCIO

RUEDA DE NEGOCIO CON PROVEEDORES DE SERVICIO E INSUMOS

RUEDA DE NEGOCIO EN COMPRA Y VENTA DE PRODUCTOS AGROPECUARIOS

RUEDA DE NEGOCIOS

SENSIBILIZACION DEL ADA

SESION DE EVALUACION DE AVANCES DE EJECUCION DEL FONDO DE INNOVACION CARLOS ILABACA

SESION DE EVALUACION DE AVANCES DE EJECUCION DEL PROYECTO FONDO DE INNOVACION CON BURKE AGRO CARLOS ILABACA

SESION DE EVALUACION DEL FONDO DE INNOVACION

SISTEMA DE PLANIFICACIÓN MUNICIPAL

SISTEMA ORGANIZACIONAL DE ALDEA GLOBAL

SISTEMAS DE TRAZABILIDAD ( CUADERNO DE REGISTRO DE FINCA )

SISTEMATIZACION DE MODULO 2 DE LA ALIANZA DE APRENDIZAJE / RECOMENDACIONES Y SUGERENCIAS

PARA NUEVA VERSION DE MODULO 2 DE LA ADA

TALLER "LLAVES PARA EL ÉXITO FINANCIERO II" PRESUPUESTO

TALLER "LLAVES PARA EL ÉXITO FINANCIERO"

TALLER ADA

TALLER ALIANZA DE APRENDIZAJE MODULO AUTOEVALUACIÓN

TALLER ALIANZA DE APRENDIZAJE MODULO I AUTOEVALUACIÓN

$68 \mid \mathrm{P}$ a g e 
TALLER ALIANZA DE APRENDIZAJE (ADA)

TALLER ALIANZA DE APRENDIZAJE MODULO II FORTALECIMIENTO DE LOS PROCESOS SOCIOORGANIZATIVOS

TALLER CADENAS DE VALOR

TALLER DE CONSOLIDACIÓN DE FONDOS REVOLVENTES

TALLER DE CONTABILIDAD, DESARROLLANDO CAPACIDADES FINANCIERAS

TALLER DE DESARROLLO EMPRESARIAL PARA COOSEMTRI

TALLER DE FORTALECIMIENTO AL PROCESO DE GRADUACIÓN DE COOPERATIVAS A.C SANDINO Y LA

ESPERANZA DE CECOCAFEN

TALLER DE FORTALECIMIENTO PARA COMITÉ DE VIGILANCIA Y COMISIÓN DE EDUCACIÓN COOPERATIVO

TALLER DE GRUPO GIAR CAFÉ CECOSEMAC

TALLER DE LA MESA NACIONAL DE CACAO

TALLER DE MARCO JURIDICO

TALLER DE PRESUPUESTO

TALLER DE VALOR AGREGADO DE PRODUCTOS AGRICOLAS

TALLER DOMINADO CHOCOLATERÍA EN PRIMERA ESCALA

TALLER EN MANEJO DE LA CALIDAD EN EL PROCESO DE ACOPIO DE CACAO EN BABA

TALLER FORTALECIMIENTO COOPERATIVO

TALLER GESTION COOPERATIVA Y LIDERAZGO

TALLER INCIDENCIA

TALLER INTRODUCTORIO SOBRE EL MANEJO DE SISTEMAS CONTABLES

TALLER PARA LA ELABORACION DE PLAN DE ACCION PARA EL FORTALECIMIENTO ORGANIZATIVO

TALLER PARA LA ELABORACION DEL PLAN DE ACCION PARA EL FORTALECIMIENTO ORGANIZATIVO

TALLER PARA LA PLANIFICACION ESTRATEGICA DE LA COOPERATIVA DE SERVICIOS MULTIPLES LA

TRINIDAD(COOSEMTRI)

TALLER PARTICIPATIVO PARA ELABORAR PLAN DE DESARROLLO DE COMULSAN

TALLER PARTICIPATIVO PARA ELABORAR PLAN DE DESARROLLO DE WISCOYOL

TALLER PROCAFTA FORTALECIMIENTO DE LAS EXPORTACIONES DE FRIJOLES

TALLER SOBRE CATACIÓN DE CACAO PARA DETERMINAR LA CALIDAD

TALLER SOBRE CONTABILIDAD Y CARTERA DIRIGIDO A ORGANIZACIONES DE PRODUCTORES EN PROCESO DE GRADUACIÓN DE ACORDAR

TALLER SOBRE COOPERATIVISMO

TALLER SOBRE EL MANEJO DE CENTROS DE ACOPIO DE CACAO PARA LOGRAR OBTENER UN PRODUCTO DE CALIDAD.

TALLER SOBRE LEGISLACIÓN COOPERATIVA LEY 499 LEY GENERAL DE COOPERATIVAS Y SU REGLAMENTO. TALLER SOBRE LEGISLACIÓN COOPERATIVA LEY 499, LEY GENERAL DE COOPERATIVAS Y SU REGLAMENTO TALLER SOBRE MECANISMO PARA LA COMERCIALIZACIÓN DE CANELA.

TALLER SOBRE PARAMETROS DE COSECHA

TALLER SOBRE PLANEACIÓN ESTRATEGICA DE LAS COOPERATIVAS

TALLER SOBRE PLANEACIÓN ESTRATEGICA DE LAS COOPERATIVAS.

TALLER SOBRE PLANIFICACIÓN COMISIÓN TERRITORIAL DE CACAO R.S.J.

TALLER SOBRE PLANIFICACIÓN ESTRATEGICA DE LA COOPERATIVA COODEPROSA R,L COMO

FORTALECIMIENTO A LA CADENA DE VALOR DE CACAO.

TALLER SOBRE REGLAMENTO INTERNO APROBACIÓN

TALLER SOBRE REGLAMENTO INTERNO.III

TALLER: ANÁLISIS Y ESTUDIO DE POLÍTICAS NICARAGUENSES DE FRIJOL.

TALLER: CAPACITACIÓN Y CONFORMACIÓN DE LOS GESTORS DE INNOVACIÓN DE AGROINDUSTRIA RURAL (GIAR).

TALLER: SEGUIMIENTO A GRADUACIÓN DE COOPERTIVAS, APODER Y CECOOP

TALLES SOBRE PLANIFICACIÓN ESTRATEGICA DE LAS COOPERATIVAS.

TÉCNICAS DE APRENDIZAJE PARA DESARROLLAR CAPACITACIONES A TRAVÉS DE LA METODOLOGÍA DE INVESTIGACIÓN POPULAR

TECNICAS DE VENTAS

TERCERA FERIAS AGROINDUSTRIAL DESARROLLO WALMART-HORTIFRUTI

TRAMITES DE EXPORTACION

TRANSFORMACION DE PRODUCTOS

TRAZABILIDAD

TRAZABILIDAD ( CUADERNO DE REGISTRO )

TRAZABILIDAD DEL CACAO

TRAZABILIDAD E INOCUIDAD DE ALIMENTOS

TRAZABILIDAD EN CACAO

TRAZABILIDAD EN FINCAS DE CAFÉ

USO Y MANEJO DE LIBRO CONTABLE

USO DE LIBRO AUXILIAR Y MAYOR

USO DE LIBROS CONTABLES DIARIO

USO Y MANEJO DE SERVICIOS FINANCIEROS Y NO FINANCIEROS

USO Y MANEJO DE CRÉDITO

USO Y MANEJO DE CRÉDITO.

USO Y MANEJO DE LIBROS EN COOPERATIVAS

USO Y MANEJO DE TECNICAS DE CREDITO

USO Y MANEJO DE TÉCNICAS DE CRÉDITO 
VALIDEZ Y EVALUACION DE LAS INSPECCIONES INTERNAS DE CERTITIFICACION ORGANICA VISIÓN EMPRESARIAL Y CADENAS DE VALOR DE CAFÉ PROMOCIÓN CONGLOMERADO DE CAFÉ

ROL ADMINISTRATIVO

SISTEMA DE CONTROL INTERNO

\section{Municipality engagement}

ACOMPAÑAMIENTO TÉCNICO PARA LA ELABORACIÓN DE PLANES DE ACCIÓN

ANALISIS Y EVALUACIÓN DE LA LEY AMBIENTAL Y DE AGUA CON CAP'S

APOYO A CABILDO MUNICIPAL DE RANCHO GRANDE

ASAMBLEA COMUNITARIA

ASAMBLEA COMUNITARIA SOBRE MUNICIPALISMO

ASAMBLEA CON AUT. MUNIC Y PROD. P ENTREGAR PROP DE DEMANDA

ASAMBLEA CON AUT. MUNIC. Y PROD. P ENTREGAR PROP DE DEMANDA

ASAMBLEA CON LIDERES COMUNITARIOS

ASAMBLEA PARA PRESENTAR DEMANDA ANTE ACTORES CLAVES Y PRODUCTORES/AS

CABILDO CON AUTORIDADES MUNICIPALES

CABILDO DE SAN NICOLAS

CABILDO INFORMATIVO CON AUTORIDADES MUNICIPALES

CABILDO MUNICIPAL

CABILDO MUNICIPAL

CABILDO MUNICIPAL CONSULTIVO 2010

CABILDO MUNICIPAL DE PRESUPUESTO SAN RAMON

CABILDO MUNICIPALES PARA PRESUPUESTO 2012

CAPACITACIÓN A LOS CAP'S EN LEY NACIONAL DE AGUA 620 Y LEY 722

CONSULTA AL PRESUPUESTO MUNICIPAL

CONSULTA ANTE EL CONSEJO MUNICIPAL

CONTEXTO PARTICIPACION CIUDADANA Y ELABORACION DE PRESUPUESTO MUNISIPAL

DELITO AMBIENTAL

DISCUSION ORDENANZA MUNICIPAL AMBIENTAL ALCALDIA ESQUIPULAS

ELABORACION DE PLANES DE ACCIÓN PARA LA INCIDENCIA EN LA MUNICIPALIDAD

ELABORACIÓN DE PLANES DE ACCION PARA LA INCIDENCIA.

ELABORACION DE PLANES DE ACCION Y MODIFICAR PRESUPUESTOS DE DEMANDA

ELABORACION DE PROPUESTA DE NECESIDADES DE LAS COOP. DEL MUNICIPIO DE MATAGALPA

ELABORACION DE PROPUESTAS Y PRESUPUESTOS MUNICIPALES

EVALUACIÓN Y PLANIFICACIÓN DEL PLAN DE ACCIÓN DE MUNICIPALISMO

FORMACIÓN DE COORDINADORES DE COMUNIDADES SOBRE EL PROCESO DE CONSULTA MUNICIPAL

FORTALECIMIENTO ORGANIZATIVO DE CAP'S

FUNCIONES DE FUNCIONARIOS DE LA ALCALDÍA

FUNCIONES DE LAS INSTUTUCIONES DE GOBIERNO PRESENTES EN EL MUNICIPIO Y FUNCIONARIOS DE LA

ALCALDÍA.

GESTIÓN DE RIESGO Y PLANIFICACIÓN MUNICIPAL

GOBERNABILIDAD Y PARTICIPACIÓN CIUDADANA

I CABILDO ORDINARIO 2012

INCIDENCIA

INCIDENCIA MUNICIPAL

INCIDENCIA POLTICA

LANZAMIENTO DEL PROCESO DE CONSULTA

LEVANTAR DEMANDAS DE NECESIDADES DE LAS COMUNIDADES

LEY 620 Y 217

LEY DE AGRICULTURA ORGÁNICA

LEY DE AGUA Y ANA

LEY DE CATASTRO MUNICIPAL

LEY DE DELITO AMBIENTAL

LEY DE FOMENTO A LA AGRICULTURA ORGANICA

LEY DE MEDIO AMBIENTE

LEY DE MUNICIPIO

LEY DE MUNICIPIO

LEY DE PARTICIPACIÓN CIUDADANA

LEY DE PARTICIPACION CIUDANA

LEY DE PARTICIPACIÓN CUIDADANA

LEY DE SOBERANIA Y SEGURIDAD ALIMENTARIA

LEY GENERAL DE MUNICIPIO

LEY GENERAL DE MUNICIPIO LEY 40

LEY IBIS

LEY SEGURIDAD ALIMENTARIA

LEYES AMBIENTALES Y PARTICIPACIÓN CIUDADANA

LEYES SOBRE LA PROTECCIÓN DEL MEDIO AMBIENTE

MANEJO DE PRESUPUESTO MUNICIPAL

MARCO JURIDICO 
MARCO JURIDICO

MARCO JURIDICO (PRESUPUESTO MUNICIPAL)

MARCO JURIDICO MUNICIPAL

MARCO JURIDICO Y PRESUPUESTO MUNICIPAL

MUNICIPALISMO

MUNICIPALISMO Y PARTICIPACION CIUDADANA

MUNICIPALISMO, TRIBUTACIÓN, CATASTRO.

MUNICIPALISMO: BARRIDO CATASTRAL Y RECUADACIÓN

MUNICIPALISMO: LEY DE IMPUESTOS DE BIENES INMUEBLES (IBI)

MUNICIPALISO:FORO DE NEGOCIACION DE LAS INVERSIONES PARA EL DESARROLLO SOSTENIBLE

ORDENANZAS MUNICIPALES SOBRE MEDIO AMBIENTE Y RECURSOS NATURALES.

ORDENANZAS MUNICIPALES, MEDIO AMBIENTE Y RECURSOS NATURALES

ORGANIZACIÓN Y LEGISLACIÓN DE CAP'S

PARTICIPACION CIUDADANA

PARTICIPACIÓN CIUDADANA

PARTICIPACION DE LA POBLACIÓN EN CONSULTA PRESUPUESTARIA

PARTICIPACION EN CABILDO MUNICIPAL PRESUPUESTO 2011

PLAN ARBITRIO

PLAN ARBITRIO

PLAN DE INCIDENCIA MUNICIPAL

PLAN DE INSIDENCIA

PLANES DE ACCCION

PLANES DE ACCIÓN PARA LA INCIDENCIA MUNICIPAL

PLANES DE INCIDENCIA

PLANES DE INCIDENCIA EN MUNICIPIO DE TERRABINA

PLANES DE INCIDENCIA MUNICIPAL

PLANES DE INSIDENCIA DEL MUNICIPIO DE JINOTEGA

POLÍTICAS PÚBLICAS EN EL MARCO DEL SISTEMA DE PLANIFICACION MUNICIPAL

PRESENTACION DAMANDAS ALCALDIA MUNICIPAL SRN

PRESENTACION DE ORDENANZA MUNICIPAL

PRESENTACIÓN DE PLANES DE INCIDENCIA

PRESENTACION DEL PLAN MUNICIPAL ALCALDIA SAN NICOLAS

PRESENTACION DEL PROYECTO AL CONSEJO MUNICIPAL

PRESENTACION DEL PROYECTO AL NUEVO CONSEJO MUNICIPAL

PRESUPUESTO MANICIPAL

PRESUPUESTO MUNICIPAL

PRIMER CABILDO INFORMATIVO

PROCESO DE ELABORACION DE PROPUESTA Y PRIORIZACION DE PROYECTOS MUCNICIPALES

REGIMEN PRESUPUESTARIO MUNICIPAL.

REUNIÓN /PRESENTACIÓN DE RESULTADOS DE INVERSIÓN EN EL MUNICIPIO POR ACORDAR.

REUNION LIDERES COMUNALES "DEMANDAS ALCALDIA"

REVISIÓN DE ORDENANZAS

REVISION DE ORDENANZAS AMBIENTALES

REVISION, ELABORACION DE PLANES DE ACCION Y PROPUESTAS DE DEMANDA

SEGUIMIENTO A PLANES DE ACCIÓN

SEGUNDO CABILDO ORDINARIO

SESION PLANIFICACION ESTRATEGICA DIRECTIVOS DE JUNTA DE VIGILANCIA

SESION PLANIFICACION ESTRATEGICA DIRECTIVOS DE JUNTA DE VIGILANCIA Y ORGANOS DE GESTION

SISTEMA DE PALNIFICACION MUNICIPAL

SISTEMA DE PLANIFICACION MUNICIPAL

SISTEMA DE PLANIFICACIÓN MUNICIPAL Y GÉNERO

SISTEMA DE PLANIFICAION MUNICIPAL

TALLER A LOS CAP'S EN AGUA Y SANEAMIENTO

TALLER DE ELABORACIÓN DE PLANES DE ACCIÓN

TALLER DE EVALUACIÓN Y PLANIFICACIÓN DE ACCIONES EN MUNICIPALISMO

TALLER DE GOBERNABILIDAD

TALLER DE REGULACIONES LOC ALES (LEY DE RECAUDACION TRIBUTARIA Y LEY 431 TRANSPORTE)

TALLER DIVULGACIÓN DE ORDENANZAS

TALLER PARA DAR A CONOCER LOS PROCESOS DE CONSULTA

TALLER PUBLICA EN EL PROCESO DE PLANIFICACION MUNICIPAL

TALLER REGULACIONES LOCALES - PLANIFICACION TERRITORIAL Y CONTROL URBANO

TALLER REGULACIONES LOCALES-LEY DEIBI

TALLER SOBRE LEY DE PARTICIPACIÓN CIUDADANA

TALLER SOBRE PLANES DE ACCION

TALLER SOBRE REGIMEN PRESUPUESTARIO MUNICIPAL

TALLER: DESARROLLO DEL PROCESO DE CONSULTA COMUNITARIA

TALLER: PLANES DE ACCIÓN COMUNITARIA

VINCULACION DEL PLAN AMBIENTAL MUNICIPAL, RECUPERACION DE LA CUENCA DE RIO VIEJO 


\title{
6.2.2. Production Program
}

\author{
Agricultural practices \\ BPA \\ BPA CALIDAD E INOCUIDAD DE PRODUCTOS AGRICOLAS MOTSA \\ BPA CALIDAD E INOCUIDAD EN MOTSA \\ BPA EN COSECHA DE OKRA Y SALUD E HIGIENE DEL PERSONAL A 70 TRABAJADORES \\ BPA SOBRE MANEJO DE PLAGUICIDAS \\ BPA/OKRA Y SALUD E HIGIENE DEL PERSONAL \\ BUENAS PRACTICAS AGRICOLAS \\ BUENAS PRÁCTICAS AGRICOLAS \\ BUENAS PRÁCTICAS AGRICOLAS \\ BUENAS PRÁCTICAS AGRÍCOLAS \\ BUENAS PRACTICAS AGRICOLAS (B.P.A) \\ BUENAS PRACTICAS AGRICOLAS (BPA) \\ BUENAS PRÁCTICAS AGRÍCOLAS (BPA) \\ BUENAS PRACTICAS AGRICÓLAS BPM \\ BUENAS PRACTICAS AGRICOLAS EN CAFÉ \\ CAPACITACIÓN SOBRE PRINCIPIOS DE BPA \\ CERTIFICACIÓN ORGÁNICA \\ CERTIFICACIONES EN BPA,BPM,HACCP Y GLOBAL GAP \\ COMPORTAMIENTO SANITARIO DEL PERSONAL DE LA PLANTA DE ACOPIO \\ ECA - WISCOYOL, TRAZADO DE BARRERAS MUERTAS A NIVEL. \\ ENTRENAMIENTO EN BPA \\ ESPECIFICACIONES SOBRE CERTIFICACIÓN DE FINCAS CON BPA. \\ GENERALIDADES DE LAS BPA \\ GIRA DE INTERCAMBIO DE EXPERIENCIA PAR CONOCER COMO DEBE ESTAR EQUIPADA UNA FINCA CON BPA \\ (CHARLA DEL MAGFOR SOBRE FINCAS BPA) \\ IMPLEMENTACION EN BPA EN FINCAS MOTSA \\ INOCUIDAD Y BUENAS PRACTICAS AGRICOLAS \\ INTERCAMBIO EN FINCA CON ENFOQUE EN BUENAS PRACTICAS AGRICOLAS (BPA) \\ INTRODUCCION A BPA, CALIDAD E INOCUIDAD DE ALIMENTOS Y ENFERMEDADES TRASMITIDAS X LOS \\ ALIMENTOS \\ LANZAMIENTO DE CERTIFICACION BPA \\ LANZAMIENTO DE CERTIFICACIÓN DE FINCAS BPA \\ LINEAMIENTOS PARA CERTIFICACIÓN DE FINCAS EN BUENAS PRACTICAS AGRICOLAS (BPA) \\ LLENADO DE REGISTRO BPA \\ MANEJO DE FINCAS EN PROCESO DE BUENAS PRACTICAS AGRICOLA (BPA) \\ MANEJO INTEGRADO DE PLAGAS BPA PARA AGRICULTURA FAMILIAR \\ MANEJO INTEGRADO DE PLAGAS EN CANELA \\ NORMAS DE INOCUIDAD \\ PRESENTACIÓN DE TECNOLOGÍAS ALTERNATIVAS: BIODINSUL, HONGO MIRABIOL,AMIGOS DE LA \\ MONTAÑA,MICRORIEGO POR GOTEO,HORNOS MEJORADOS Y BIODIGESTORES. \\ REVISIÓN DE OBRAS Y CHECK LIST EXIGIDAS POR MAGFOR PARA CERTIFICACIÓN DE BPA. \\ SEMINARIO BASICO DE PRIMEROS AUXILIOS Y USO DE EXTINTORES \\ TALLER BPA Y MANEJO INTEGRADO DE PLAGAS. \\ TALLER DE BUENAS PRÁCTICAS PARA EL MANEJO DE AGUA DE CONSUMO \\ TALLER DE EVALUACIÓN Y PLANIFICACIÓN DE PLAN DE ACCIÓN DE LAS COOPERATIVAS \\ TALLER DE FINCAS BPA Y DEMOSTRACIÓN PRACTICA DEL PRODUCTO ZAPICOL 53. \\ TRAZABILIDAD EN LA PRODUCCIÓN DE ALIMENTOS. \\ VIAJE DE INTERCAMBIO DE EXPERICIAS EN FINCAS BPA
}

\section{Agricultural production}

PRODUCCIÓN DE SEMILLA DE FRÍJOL

ABONOS ORGANICOS

ACTUALIZACIÓN DE CÓSTOS DE PRODUCCIÓN DE HORTALIZAS Y USO DEL PERSUAP

ACTUALIZACIÓN DE COSTOS DE PRODUCCIÓN DEL CULTIVO DE LA MALANGA

ACTUALIZACION DE CÓSTOS DE PRODUCCIÓN DEL FRIJOL Y TOMATE

ACTUALIZACIÓN DE CÓSTOS DE PRODUCCIÓN Y PERSUAP

ADECUADO ESTABLECIMIENTO Y MANEJO DE SEMILLEROS Y VIVEROS DE CAFÉ

AGICULTURA PROTEGIDA EN PAPA

AGROFORESTERIA EN CACAO

ALTERNATIVAS PARA MEJORAR LA PRODUCTIVIDAD DE HORTALIZAS EN AMBIENTE DE ALTA PLUVIOCIDAD

ANALISIS DE COSTOS DE PRODUCCION

ANALISIS DE COSTOS SEGÚN CUADERNO DE REGISTRO

ANALISIS DE SUELO

ANALISIS DE UN AGRO ECOSISTEMA

ANALISIS E INTERPRETACION DE RESULTADOS DE CATACION DE CAFÉ 
ANÁLISIS SOBRE PRÁCTICAS PREVENTIVAS DE LA ECA

APLICACIÓN DE FERTILIZANTES HIDROSOLUBLES

ARBOLES SUPERIORES Y BIOLOGIA REPRODUCTIVA DE CACAO

ASAMBLEA GENERAL ORDINARIA

ASAMBLEA INFORMATIVA CON SOCIOS DE LAS COOPERATIVA SABANA GRANDE.

ASPECTO PRODUCTIVOS EN FRIJOL

ASPECTOS PRODUCTIVOS DE CACAO

ASPECTOS PRODUCTIVOS EN FRIJOL

BALANCE NUTRICIONAL PARA CAFÉ

BENEFICIADO DE LA SEMILLA DE FRIJOL

BENEFICIADO HÚMEDO DE CAFÉ Y SU GESTIÓN AMBIENTAL.

BENEFICIADO HUMEDO DEL CAFÉ

BENEFICIADO HÚMEDO DEL CAFÉ

BENEFICIADO Y CALIDAD DEL CAFÉ

BENEFICIO HUMEDO

BENEFICIO HÚMEDO CAFÉ

BENEFICIO HÚMEDO DEL CAFÉ

BUENAS PRACTICAS AGRICOLAS

BUENAS PRACTICAS AGRÍCOLAS

BUENAS PRÁCTICAS AGRICOLAS

BUENAS PRÁCTICAS AGRÍCOLAS / USO DE PERSUAP/HORTALIZAS

BUENAS PRACTICAS AGRICOLAS EN CAFÉ (BPA)

BUENAS PRACTICAS AGRICOLAS EN CAFÉ (BPA)

BUENAS PRACTICAS AGRICOLAS EN RAÍCES Y TUBERCULOS

BUENAS PRACTICAS AGRÍCOLAS/RAÍCES Y TUBÉRCULOS

BUENAS PRACTICAS DE MANUFACTURA

BUENAS PRÁCTICAS DE MANUFACTURA

BUENAS PRACTICAS DE MANUFACTURA (POSTCOSECHA)

BUENOS PRACTICAS AGRICOLAS

CALIBRACION DE BOMBAS DE MOCHILAS Y PREPARACION DE BIOFERTILIZANTES

CALIBRACION DE EQUIPOS

CALIBRACIÓN DE EQUIPOS Y DOSIFICACIÓN DE PRODUCTOS

CALIBRACIÓN DE EQUIPOS, DOSIFICACIÓN DE PLAGUICIDAS Y MIP

CALIBRACIÓN DE MÁQUINAS DESPULPADORAS

CALIBRACION Y AJUSTES DE MOCHILAS EN PRODUCTOS QUIMICOS

CALIDAD CORTE Y BENEFICIADO

CALIDAD DE APLICACIÓN CON BOMBA DE MOCHILA

CALIDAD DE LA SEMILLA DE FRIJOL

CALIDAD DEL BENEFICIADO HUMEDO DEL CAFÉ

CALIDAD DEL CAFÉ

CALIDAD DEL CAFÉ

CALIDAD Y PROCESOS DE EXPORTACIÒN DE CAFÈ

CALIDAD Y PRODUCTIVIDAD

CAPACIT EN PLAGAS Y ENFERMEDADES DE HORTALIZAS

CAPACITACION A PROMOTORES EN AGROFORESTERIA

CAPACITACION A PROMOTORES EN BENEFICIADO HUMEDO

CAPACITACION A PROMOTORES EN ESTIMADO DE COSECHA EN CAFÉ

CAPACITACION A PROMOTORES EN MANEJO DE PLAGAS EN CAFÉ

CAPACITACION A PROMOTORES EN MANEJO DE PLAGAS Y ENFERMEDADES EN CAFÉ

CAPACITACION A PROMOTORES EN MANEJO DE VIVERO Y SEMILLERO

CAPACITACION A PROMOTORES SOBRE ESTIMADO DE COSECHA

CAPACITACION A PROMOTORES SOBRE MANEJO DE SEMILLERO Y VIVERO EN CAFÉ

CAPACITACION DE SISTEMA FORESTALES

CAPACITACION DIRECTIVOS: POLITICAS Y ESTRATEGIAS DE GENERO DEL PROYECTO ACORDAR

CAPACITACION EN MANEJO DE VIVERO EN CAFÉ

CAPACITACIÓN EN ASPECTOS PRODUCTIVOS EN FRIJOL

CAPACITACIÓN EN BPA, DIAGNOSTICO SOBRE LA PROBLEMÁTICA DE COMERCIALIZACIÓN EN RAÍCES Y

TUBÉRCULOS.

CAPACITACION EN ESTIMADO DE COSECHA Y FERTILIZACION EN CAFÉ

CAPACITACION EN INJERTO DE CACAO E IDENTIFICACION

DE ARBOLES SUPERIORES DE CACAO

CAPACITACION EN MANEJO DE SEMILLERO Y VIVERO, Y FERTILIZACION DE CAFÉ

CAPACITACION EN MANEJO DE TEJIDOS EN CAFÉ

CAPACITACION EN MANEJO DE TEJIDOS EN CAFÉ

CAPACITACION EN MANEJO DE TEJIDOS Y BENEFICIADO HUMEDO

CAPACITACION EN PODA O MANEJO DE TEJIDO EN CAFÉ

CAPACITACIÓN EN PRODUCCIÓN DE FRIJOL CON NUEVAS TÉCNICAS

CAPACITACIÓN EN PRODUCCIÓN DE FRIJOL, PROGRAMA FRIJOL NICA DE RAMAC

CAPACITACION EN SISTEMAS AGROFORESTALES

CAPACITACION SISTEMA AGROFORESTALES

CAPACITACION SOBRE AGROFORESTERIA 
CAPACITACION SOBRE FERTILIDAD DE CAFÉ

CAPACITACION SOBRE FERTILIZACION DE CAFÉ Y BENEFICIADO HUMEDO

CAPACITACION SOBRE IDENTIFICACION DE DEFICIENCIA Y FERTILIZACION EN CAFÉ

CAPACITACION SOBRE MANEJO DE BIODIGESTORES.

CAPACITACION SOBRE MANEJO DE TEJIDOS EN CAFÉ

CAPACITACION SOBRE MANEJO DE TEJIDOS EN EL CAFÉ

CARACTERISTICAS AGRONOMICAS DE INTA CARDENAS Y FITOPROTECCION DUWEST EN CULTIVO DE FRIJOL CARBONIZANDO CASCARILLA DE ARROZ PARA USO COMO SUSTRATO EN PRODUCTORES DE PLANTULAS

CERFICACION DE FINCAS ECOLGOICAS

CERFICACION DE FINCAS ECOLGOICAS

CERTIFICACIÓN

CERTIFICACIÓN DE CACAO

CERTIFICACION DE FINCAS

CERTIFICACIÓN DE FINCAS

CERTIFICACIÓN DE FRUTALES Y VEGETALES

CERTIFICACIÓN DEL CAFÉ

CERTIFICACION ORGANICA DE CAFÉ

CHARLA PRACTICA EN ELABORACIÓN DE BIOFERTILIZANTES.

CHILE PICANTE

COMERCIALIZACION DE FRIJOL

COMO HACER INSTALACION DE SISTEMA DE RIEGO POR ASPERSION Y SUS BENEFICIOS

COMO PREPARAR EL TERRENO Y SIEMBRA DE SEMILLA DE ZANAHORIA

COMPOSICIÓN DE ABONOS ORGANICOS

CONCEPTOS PRACTCOS SOBRE EL CULTIVO DE MELÓN

CONGRESI INTERNACIONAL MIP

CONOCIENDO LOS PLAGUICIDAS, INGREDIENTES ACTIVOS.

CONSIDERACIONES PARA UN ADECUADO ESTABLECIMIENTO DE SEMILLEROS Y VIVEROS CAFÉ CONSIDERACIÓNES PARA UN ADECUADO ESTABLECIMIENTO DE SEMILLEROS Y VIVEROS DE CAFÉ

CONTAMINANTES ORGANICOS

CONTOL DE MALEZAS Y FERTILIZACION EN MUSACEAS

CONTROL BIOLOGICO DE LA BROCA

CONTROL DE BACTERIAS EN TOMATE.

CONTROL DE CALIDAD EN BENEFICIADO SECO

CONTROL DE CALIDAD EN RAICES Y TUBERCULOS

CONTROL DE CALIDAD Y CAMBIO CLIMATICO

CONTROL DE ENFERMEDADES FUNGOSAS

CONTROL DE ERWINIA Y PSEUDOMONAS EN MUSACEAS

CONTROL DE PLAGAS Y ENFEMEDADES EN FRUTALES Y MUSACEAS

CONTROL DE PLAGAS Y ENFERMEDADES EN FRUTALES

CONTROL DE PLAGAS Y ENFERMEDADES EN GRANADILLA

CONTROL DE SIGATOCA Y PUNTA NEGRA

CONTROLADOR BIOLOGICO DE ENFERMEDADES FUNGICAS CON TRICHODERMA HARZIANUM

CORTE, DESPULPADO Y GRADO DE FERMENTACION DEL CAFE

COSECHA Y BENEFIADO HÚMEDO DE CAFÉ ORGÁNICO

COSECHA Y POST COSECHA DE R\&T

COSECHA Y TRANSPORTE DE TOMATE CON MANEJO BPA

COSTO DE PRODUCCION CAFÉ

COSTO DE PRODUCCIÓN DEL CULTIVO DE CACAO

COSTOS DE PROD. FRIJOL Y CAFÉ

COSTOS DE PRODUCCION

COSTOS DE PRODUCCIÓN DE RAICES Y TUBERCULOS

COSTOS DE PRODUCCION FRIJOL

COSTOS DE PRODUCCION FRIJOL/TOMATE/CHILTOMA

COSTOS DE PRODUCCION MALANGA LILA

COSTOS DE PRODUCCION PLATANO

COSTOS DE PRODUCCION PLATANO Y MALANGA LILA

COSTOS DE PRODUCCION REPOLLO Y PAPA

COSTOS DE PRODUCCION TOMATE

COSTOS Y MARGENES DE PRODUCCIÓN Y COMERCIALIZACIÓN.

CROMATOLOGIA Y FERTILIDAD SUELOS

CUIDO Y MANEJO DE LA LOMBRICULTURA

CULTIVO DE CACAO

CULTIVO DE FRIJOL

CULTIVO DE RAICES Y TUBERCULOS

CULTIVO DEL CACAO

CURSO EN PRODUCCIÓN DE HONGOS ENTOMOPATOGENOS: TRICHODERMA HARSIANUM Y BEAUVERIA BASSIANA.

DEFICIENCIAS NUTRICIONALES EN HORTALIZAS.

DEMOSTRACIÓN DE PRÁCTICAS BPA Y EVALUACIÓN DE TECNOLOGÍAS EN LAS ECAS.

DEMOSTRACION DE TRABAJO EN ECA

DEMOSTRACIÓN PRÁCTICA DE ZAPICOL 53 EN TOMATE Y FRIJOL. 
DESINFECCIONY PREPARACION DE SUELO.

DIA DE CAMPO

DIA DE CAMPO A TOMATOYA

DÍA DE CAMPO CARRETA QUEBRADA CULTIVO DE TOMATE

DIA DE CAMPO COSTOS DE PRODUCCION Y USO DE PESTICIDAS

DIA DE CAMPO DE FRIJOL NEGRO

DÍA DE CAMPO ECA TOMATE, EL COYOL

DIA DE CAMPO EN CACAO

DIA DE CAMPO EN EL CULTIVO DE CACAO

DIA DE CAMPO EN EL CULTIVO DE FRIJOL

DIA DE CAMPO EN FRIJOL

DÍA DE CAMPO EN HORTALIZAS PARA EVALUAR DOS HIBRIDOS DE TOMATE( PONYS Y HALYANA) EN

TOMATOYA - JINOTEGA

DIA DE CAMPO INSTALACIÓN DE SISTEMA DE RIEGO POR GOTEO

DIA DE CAMPO PARA ESTABLECIMIENTO DE PARCELAS DE VALIDACIÓN EN FRIJOL

DIA DE CAMPO SOBRE EL CULTIVO DE REPOLLO

DIA DE CAMPO, REPRODUCCIÓN DE PLANTULAS

DÍA DE CAMPO: HORTALIZAS E INTERCAMBIO DE EXPERIENCIA

DIAGNÓSTICO CAFÉ ORGÁNICO

DIAGNOSTICO FITOSANITARIO COMO BASE DEL MANEJO INTEGRADO DE DE PLAGAS EN CACAO

DIAGNOSTICO FITOSANITARIO COMO BASE DEL MANEJO INTEGRADO DE PLAGAS

DIAGNOSTICO FITOSANITARIO COMO BASE DEL MANEJO INTEGRADO DE PLAGAS

DIAGNÓSTICO FITOSANITARIO COMO BASE DEL MANEJO INTEGRADO DE PLAGAS

DIAGNÓSTICO FITOSANITARIO COMO BASE DEL MANEJO INTEGRADO DE PLAGAS EN CACAO

DIAGNOSTICO PRODUCTIVO DE CAFÉ Y ELABORACIÓN DE TRAMPAS MANEJO DE BROCA

DIAGNOSTICO PRODUCTIVO Y RECUENTO DE PLAGAS Y ENFERMEDADES

DIAGNOSTICO Y PLANIFICACION DE FINCA

DIÁNOSTICO PRODUCTIVO DE CAFETALES PARCELAS VALIDACIÓN

DIFERENCIAS DE RESISTENCIA A

VIROSIS DE SHANTY, XAMAN Y NATIVO

DISEÑO DE SISTEMAS AGROFORESTALES

DISEÑO Y ESTABLECIMIENTO DE CACAO EN SISTEMAS AGROFERESTALES

DISEÑO Y ESTABLECIMIENTO DE SISTEMAS AGROFORESTALES

DIVERSIFICACIÓN DE LA PRODUCCIÓN

DIVERSIFICACIÓN PRODUCTIVA

ECA - WISCOYOL; IDENTIFICAR TOXICIDAD DE PLAGUICIDAS

ECA - WISCOYOL; RECUENTO DE COSECHA.

ECA FRIJOL NEGRO; VALIDACIÓN DE PROGRAMA FRIJOL NICA

ECA FRIJOL; CALIBRACIÓN DE EQUIPOS DE FUMIGACIÓN

ECA FRIJOL; CONTROL DE MALEZAS DE FRIJOL

ECA FRIJOL; CONTROL DE MALEZAS, PREPARACIÓN DEL TERRENO

ECA FRIJOL; CONTROL DE PLAGAS Y ENFERMEDADES DE FRIJOL.

ECA FRIJOL; GERMINACIÓN Y CÁLCULO DE DENSIDAD POBLACIONAL DE ÁREA DE FRIJOL

ECA FRIJOL; IMPORTANCIA DE LOS REGISTROS DE PRODUCCIÓN.

ECA FRIJOL; MANEJO INTEGRADO DE PLAGAS

ECA FRIJOL; MUESTREO DE PLAGAS Y ENFERMEDADES

ECA FRIJOL; SIEMBRA Y FERTILIZACIÓN DE FRIJOL

ECA, CONTROL DE ENFERMEDADES Y ESTAQUILLADO

ECA, ELABORACIÓN DE CALDO SULFOCÁLSICO Y BIOFERTILIZANTES

ECA, INSTALACIÓN DE SISTEMA DE RIEGO

ECA, PRUEBA DE GERMINACIÓN Y PREPARACIÓN DE TERRENO

ECA, PRUEBA DE GERMINACIÓN Y PREPARACIÓN DE TERRENO II PARTE

ECA, TRASPLANTE DE TOMATE

ECA, TUTOREO DE TOMATE

ECA, TUTOREO DE TOMATE Y CONTROL DE MALEZAS

ECA/IDENTIFICACIÓN DE ENFERMEDADES

ECA; ACUERDOS DE RESULTADOS DE LA COSECHA DE TOMATE

ECA; ARRANCA (COSECHA Y POST COSECHA) DE FRIJOL

ECA; CONCLUSIONES Y RECOMENDACIONES DE POST COSECHA CULTIVO DE TOMATE

ECA; CONTROL DE MALEZAS

ECA; COSECHA DE TOMATE

ECA; ESTIMADO DE COSECHA DE FRIJOL

ECA; LEVANTAMIENTO DE RASTROJOS DE TOMATES

ECA; PRÁCTICAS DE ENTUTORADO

ECA; USO Y UBICACIÓN DE TRAMPAS OLOROSAS

ECA-CACAO

EL PROCESO DE INSPECCIÓN INTERNA EN FINCAS ORGÁNICAS DE LAS FAMILIAS DE COOPROCAFUC ELABORACION DE BIOFERTILIZANTES

ELABORACION DE BIOFERTILZANTES, CALDOS E IMPORTANCIA DEL TRIPLE LAVADO

ELABORACIÓN DE CALDOS BORDELES Y SULFOCÁLCICOS PARA EL CONTROL DE PLAGAS Y ENFERMEDADES

ELABORACIÓN DE PLANES DE FINCA 
ELABORACIÓN DE PRODUCTOS AGROECOLOGICO PARA EL CONTROL DE PLAGAS DE CACAO. ELABORACION DE PRODUCTOS AGROECOLOGICOS PARA EL CONTROL DE PLAGAS EN CACAO ELABORACIÓN DE PRODUCTOS AGROECOLOGICOS PARA EL CONTROL DE PLAGAS EN CACAO. ELABORACIÓN DE PRODUCTOS AGROECOLÓGICOS PARA EL CONTROL DE PLAGAS Y ENFERMEDADES EN CACAO

ELABORACION DE PRODUCTOS ORGANICOS PARA DE AGRICOLA, SULFOCALCIO Y BIOFERMENTADOS ELEMENTOS ESENCIALES EN LA METODOLOGIA DE CAMAPESINO A CAMPESINO.

ENCUETRO LATINOAMERICANO DE AGRICULTURA ECOLOGICA

ENFERMEDADES DE LA CHILTOMA.

ENFERMEDADES DEL CACAO

ENMIENDAS DE SUELO Y MANEJO NUTRICIONAL PARA EL CULTIVO DE PIÑA MD- 2

ENMIENDAS EDAFICAS, MANEJO DE NUTRINTES Y MANEJO DE CUCURBITACEAS

ENMIENDAS MINERALES Y ORGÁNICAS

ESCUELA DE CAMPO EN EL CULTIVO DE LECHUGA 3RA EDICION

ESCUELA DE CAMPO EN EL CULTIVO DE LECHUGA-SEGUNDA EDICION

ESCUELA DE CAMPO EN EL CULTIVO DE REPOLLO

ESCUELA DE CAMPO, IMPORTANCIA, IDENTIFICACION DE LOS PRINCIPALES PROBLEMAS DEL CULTIVO DE CACAO.

ESCUELA DE CAMPO, IMPORTANCIA, IDENTIFICACIÓN DE LOS PRINCIPALES PROBLEMAS DEL CULTIVO DE CACAO.

ESCUELA DE CAMPO/DIAGNOSTICO FITOSANITARIO COMO BASE DEL MANEJO INTEGRADO DE PLAGAS

ESCUELA DE CAMPO/MANEJO DE ENFERMEDADES

ESCUELA DE CAMPO: CULTIVO DE LECHUGA / PRIMERA EDICION

ESCUELAS DE CAMPO/ DIAGNOSTICO FITOSANITARIO COMO BASE DEL MANEJO INTEGRADO DE DE PLAGAS EN CACAO

ESCUELAS DE CAMPO/DIAGNOSTICO FITOSANITARIO COMO BASE DEL MANEJO INTEGRADO DE DE PLAGAS

EN CACAO

ESTABLECIMIENTO DE CACAO EN SAF

ESTABLECIMIENTO DE CACAO EN SISTEMAS AGROFORESTALES

ESTABLECIMIENTO DE CULTIVO DE CHILE

ESTABLECIMIENTO DE ESCUELA DE CAMPO (ECA)

ESTABLECIMIENTO DE PLANTULAS DE REPOLLO

ESTABLECIMIENTO DE SEMILLEROS Y MANEJO DE VIVEROS DE CAFÉ

ESTABLECIMIENTO DE SEMILLEROS Y VIVEROS

ESTABLECIMIENTO DE TRAMPAS PARA INSECTOS

ESTABLECIMIENTO DE VIVEROS DE CACAO

ESTABLECIMIENTO SISTEMAS AGROFORESTALES

ESTABLECIMIENTO Y MANEJO DE VIVEROS DE CACAO

ESTABLECIMIENTOS DE VIVEROS EN CACAO

ESTANDARES DE CALIDAD EN R\&T

ESTIMADO DE COSECHA EN PAPA

ESTRATEGIAS DE MANEJO DE PARATRIOZA

EVALUACIÓN DE ANALISIS DE SUELO

EVALUACIÓN DE DISEÑOS DE SIEMBRA

EVALUACIÓN DEL PROCESOS DE INSPECCIÓN INTERNA EN NUEVA QUEZADA

EVALUACIÓN SOBRE SIEMBRA DE FRÍJOLES

EXPERIENCIAS CON PRODUCTORES QUE CULTIVAN CHILE JALAPEÑO

FABRICACION DE BIOFERTILIZANTE Y ABONO TIPO BOCASHI.

FERIA AGRICOLA NAVIDEÑA

FERIA AGROALIMENTARIA FAO

FERIA AGROPECUARIA

FERIA AMBIENTAL

FERIA CAMPESINA

FERIA CAMPESINA

FERIA CAMPESINA DE PRODUCTOS ECOLOGICOS

FERIA DE CONOCIMIENTO

FERIA DE EXPO APEN

FERIA DE LA PAPA Y EL MAÍZ

FERIA DE MAIZ

FERIA DE SEGURIDAD ALIMENTARIA

FERIA E INAUGURACIÓN " CENTRO DE ACOPIO Y EMPAQUE DE RAÍCES TROPICALES".

FERIA EXPICA

FERIA HORTICOLA

FERIA HORTICULA

FERIA LATINOAMERICANO DE PRODUCTOS ECOLOGICOS

FERIA MICRO REGIONAL DEL MAIZ

FERIA NACIONAL DE LA PAPA

FERIA REGIONAL ECOLOGICA

FERIA SEGURIDAD ALIMENTARIA

FERTILIDAD DE LOS SUELOS

FERTILIDAD DE SUELO 
FERTILIDAD INOCUIDAD Y MANEJO DE SUELOS

FERTILIZACION

FERTILIZACION CACAO

FERTILIZACIÓN DE CACAO

FERTILIZACION DEL CULTIVO DEL CAFÉ

FERTILIZACIÓN DEL CULTIVO DEL CAFÉ

FERTILIZACIÓN EN CACAO

FERTILIZACION FOLIAR

FERTILIZACIÓN FOLIAR Y USO DE MOTOBOMBAS

FERTILIZACION SOLUBLE PARA HORTALIZAS

FERTILIZACIÓN Y MANEJO DE TEJIDO

FERTILIZANTES FOLIARES

FERTILIZANTES FOLIARES EN HORTALIZAS

FERTIRRIGACIÓN

FICHA AGRICOLA DE HORTALIZAS

FISIOLIGIA Y NECESIDADES NUTRICIONALES DEL CULTIVO DE CAFÉ

FISIOLOGÍA DEL CAFÉ

FISIOLOGÍA DEL CULTIVO DE CAFÉ

FISIOLOGÍA VEGETAL Y NECESIDADES NUTRICIONALES DEL CAFÉ

FORO DE RAICES Y TUBERCULOS

FORO PRODUCCION DIVERSIFICADA Y PROVISION DE SERVICIOS AMBIENTALES EN EL SECTOR CACAOTERO FORTALECIMIENTO DE LAS CAPACIDADES TECNICAS EN CERTIFICACIÓN ORGANICA Y SIC.

FORTALECIMIENTO ORGANIZATIVO Y SISTEMA DE RIEGO POR GOTEO

FRIJOL DE RIEGO (PRODUCCION DE SEMILLA)

FUNCION DEL INOCULANTE NITRONAT EN FRIJOL

FUNCIONAMIENTO AGROECOLOGICO DE LOS SISTEMAS AGROFORESTALES

GENERALIDADES DE BPA Y MIP

GIRA "MANEJO AGRONOMICO Y RENTABILIDAD DE LA BERENJENA"

GIRA A GATEMALA " PRODUCCION DE PLANTULAS BAJO INVERNADERO"

GIRA A GUATEMALA " PRODUCCION DE PLANTULAS BAJO INVERNADERO"

GIRA A PUEBLO PARA OBSERVAR EL COMPORTAMIENTO DE VARIEDADES DE TOMATE Y SISTEMAS DE RIEGO

GIRA DE CAMPO " PRESENTACION DE HIBRIDO REPOLLO BRAVO F1 ETAPA DE RIEGO Y EN DIFERENTES

ETAPAS FEMOLOGICAS"

GIRA DE CAMPO A PLANTACIÓN DE PIÑA MD-2 DEL PRODUCTOR RONAL CASCO

GIRA DE CAMPO EN EL CULTIVO DE CEBOLLA AMARILLA

GIRA DE CAMPO EN PLANTACIONES DE PIÑA.

GIRA DE CAMPO EN RAICES Y TUBERCULOS

GIRA DE CAMPO, A PLANTACIONES DE PIÑA MD - 2 EN DESARROLLO Y PRODUCCION

DONDE EL PRODUCTOR RONALD CASCO VILLALOBO EN EL CHASMOLAR Y BERNAL MIRANDA EN LA

ESPERANCITA.

GIRA DE COMERCIALIZACION DE HORTALIZAS Y PAPAYA

GIRA DE COMERCIALIZACION DE PRODUCTOS HORTICULAS

GIRA DE EXPERIENCIA SOBRE PIÑA MD- 2 A PITAL DE SAN CARLOS COSTA RICA

GIRA DE INTERCAMBIO PARA ANALIZAR EL RIEGO POR GOTEO CON BOMBAS DE PEDAL.

GIRA DE INTERCAMBIO A COPRAHOR

GIRA DE INTERCAMBIO A LA FHIA -HONDURAS EN EL RUBRO CACAO

GIRA DE INTERCAMBIO A PROPICA Y DEL ORO

GIRA DE INTERCAMBIO DE EXPERIENCIA CON PRDOCUTORES DE PLÁTANO DE QUILALI Y PRODUCTORES DE PLÁTANO DE LA COOPERATIVA COPLOX DE TONALÁ CHINANDEGA

GIRA DE INTERCAMBIO DE EXPERIENCIA SOBRE BERENJENA

GIRA DE INTERCAMBIO DE EXPERIENCIA SOBRE PRODUCCIÓN DE PLÁNTULAS DE INVERNADERO.

GIRA DE INTERCAMBIO DE EXPERIENCIAS

GIRA DE INTERCAMBIO DE EXPERIENCIAS A JALAPA PARA SELECCIÓN DE SITIO PROPUESTO PARA

CONSTRUCCION DE LAGUNETAS

GIRA DE INTERCAMBIO DE EXPERIENCIAS ENTRE PRODUCTORES DE FRIJOL

GIRA DE INTERCAMBIO DE EXPERIENCIAS PARA CONOCER MANEJO AGRONOMICO DE PLATANO

GIRA DE INTERCAMBIO DE EXPERIENCIAS, EN MANEJO DE PLÁNTULAS EN TUNELES, SUSTRATOS, SISTEMAS

DE RIEGO, MANEJO POSTCOSECHA. POR SEBACO Y JINOTEGA.

GIRA DE INTERCAMBIO EN RIVAS EN COOPERATIVA COOSAPUR

GIRA DE INTERCAMBIO PARA CONOCER EL MANEJO Y PROCESO DEL CULTIVO DE CACAO EN LA ZONA DE

RIO SAN JUAN Y EL DISEÑO DE CONSTRUCCIÓN DE SUS ÁREAS DE PROCESO.

GIRA EN PARCELA DEMOSTRATIVA DE QUEQUISOUE LILA EN COMARCA GUINEA VIEJA

GIRA EXTERNA CULTIVO DE CACAO

GIRA EXTERNA PARA CONOCER EXPERIENCIA ORGANIZATIVA

GIRA INTERCAMBIO BENEFICIADO SECO Y CATACION DE CAFÉ

GIRA INTERCAMBIO BENEFICIADO Y CALIDAD DEL CAFÉ

GIRA INTERCAMBIO SOBRE MANEJO DE CULTIVO DE CACAO

GIRA MANEJO FITOSANITARIO DE VEGETALES CHINOS

GIRA PARA COMPARTIR CONOCIMIENTOS EN LA PRODUCCION DE LOMBRIHUMUS

GIRA SISTEMAS AGROFORESTALES 
GIRAS DE CAMPO, CULTIVO DE PAPA

GRANOS BASICOS

GRANOS BÁSICOS

HORTALIZA CON RIEGO POR GOTEO

IDENTIFICACIÓN DE PLAGAS DE FOLLAJE

IDENTIFICACIÓN DE PLAGAS DE SUELO

IDENTIFICACION DE PLAGAS Y

ENFERMEDADDES DEL TOMATE

IDENTIFICACIÓN DE PLAGAS Y ENFERMEDADES.

IDENTIFICACION Y MANEJO DE PLAGAS DEL CAFÉ

III FORO GESTIÓN DEL CONOCIMIENTO EN EL SECTOR CACAOTERO MUNDIAL: CONCEPTO Y EXPERIENCIA III FORO GESTIÓN DEL CONOCIMIENTO EN EL SECTOR CACAOTERO MUNDIAL: CONCEPTO Y EXPERIENCIA IMP.ABONOS ORGANICOS

IMPORTANCIA DE LA CERTIFICACIÓN ORGANICA, NORMAS Y PROCEDIMIENTO

IMPORTANCIA DE SEMILLA MEJORADA Y NUTRICION EN CULTIVO DE FRIJOL

IMPORTANCIA DEL CULTIVO DE RAICES

IMPORTANCIA LOS REGISTROS DE BPA DE INTERPRETACION DE ANALISIS AGUA SEGÚN SEGÚN NTON 05-00708

IMPORTANCIA SOBRE MICROORGANISMOS DEL SUELO

IMPORTANCIA USO DE SEMILLA MEJORADA Y PRACTICAS MIP EN CULTIVON DE FRIJOL

INAUGURACIÓN DE CENTRO AGROINDUSTRIAL DEL NORTE DE CECOPSEMEIN

INDICADORES DE FERTILIDAD DE SUELO Y ESTUDIO ECONOMICO DEL PEPINO

INICIO ECA - WISCOYOL PREPARACIÓN DE TERRENO

INJERTACIÓN DE CAFÉ

INSTALACION DE PRE-SECADORES SOLARES

INSTALACION DE SISTEMA DE RIEGO POR GOTEO

INTERCAMBIO DE EXPERIENCIA

INTERCAMBIO DE EXPERIENCIA CON COMPRADORES DE CAFÉ

INTERCAMBIO DE EXPERIENCIA CON COMPRADORES DE CAFÉ

INTERCAMBIO DE EXPERIENCIA CON PERSONAS DE ACDI

INTERCAMBIO DE EXPERIENCIA EN CACAO

INTERCAMBIO DE EXPERIENCIA EN CACAO

INTERCAMBIO DE EXPERIENCIA ENTRE ESCUELAS DE CAMPO

INTERCAMBIO DE EXPERIENCIA: PRODUCCIÓN DE SEMILLA Y ALMACENAMIENTO DE PAPA.

INTERCAMBIO DE EXPERIENCIAS CON PRODUCTORES

INTERCAMBIO DE EXPERIENCIAS:MANEJO DE PLANTULAS BAJO TECHO ( INVERNADEROS)

INTERCAMBIO DE PRODUCTORES ORGANICOS

INTERCAMBIO MANEJO FITOSANITARIO DEL CULTIVO REPOLLO

INTERCAMBIO SOBRE BENEFICIADO HÚMEDO Y CALIDAD DEL CAFÉ

INTERCAMBIO SOBRE BENEFICIADO SECO DE CAFÈ

INTERCAMBIO TECNICO EN MANEJO DE TEJIDO

INTERCAMBIO/EXPERIENCIA/CONSTRUCCION/BENEFICIOS HUMEDOS

INTERCAMBIO/EXPERIENCIAS/SISTEMAS/PRODUCCIÒN DEL CAFÈ

INTERECAMBIO DE EXPERIENCIA EN MANEJO DE PLANTULAS DE HORTALIZAS Y DEMOSTRACIÓN PRACTICA

DEL PRODUCTO BIOLÓGICO ZAPICOL 53.

INTERPRETACION ANALISI FOLIARES

INTERPRETACION ANALISIS ABONOS ORGANICOS

INTERPRETACIÓN DE ANÁLISIS DE CATACIÓN

LA VIDA EN EL SUELO, Y ELABORACION DE BIOFERTILIZANTE FERMENTADO

LLENADO DE CUADERNO DE REGISTRO DE PRODUCCION

LLENADO DE FICHAS DE REGISTRO DE FINCAS BPA

LLENADO DE FORMATOS PARA CERTIFICACIÓN ORGANICA

LOMBRICULTURA

MANEJO INTEGRADO DE PLAGAS

MANEJO AGROFORESTAL EN FINCAS DE CACAO

MANEJO AGRONOMICO DE BERENJENA

MANEJO AGRONOMICO DE CHILTOMA

MANEJO AGRONOMICO DE CULTIVO DE FRIJOL

MANEJO AGRONOMICO DE FRIJOL NEGRO PARA SEMILLA CERTIFICADA

MANEJO AGRONOMICO DE LA MALANGA

MANEJO AGRONÓMICO DE LA PAPA

MANEJO AGRONOMICO DE LA PAPAYA

MANEJO AGRONOMICO DE VEGETALES ASIATICOS

MANEJO AGRONOMICO DEL CACAO

MANEJO AGRONOMICO DEL CULTIVO DE FRIJOL

MANEJO AGRONOMICO DEL CULTIVO DE MAIZ

MANEJO AGRONÓMICO DEL CULTIVO DE YUCA.

MANEJO AGRONOMICO DEL CULTIVO DEL CACAO

MANEJO AGRONÓMICO DEL CULTIVO DEL CACAO

MANEJO AGRONÓMICO DEL CULTIVO DEL PLÁTANO

MANEJO AGRONOMICO DEL FRIJOL DE APANTE 
MANEJO AGRONOMICO SEMILLA FRIJOL

MANEJO AGRONÓMICO Y PRODUCCIÓN DE SEMILLA DE FRIJOL

MANEJO DE CAFÉ ORGANICO

MANEJO DE AGUA MIELES

MANEJO DE CACAO

MANEJO DE CACAO EN SISTEMAS AGROFORESTALES

MANEJO DE CULTIVO DE TOMATE APLICACIÓN DEL PERSUAP

MANEJO DE CULTIVO DEL FRIJOL

MANEJO DE DESECHOS SÓLIDOS Y LÍQUIDOS DE LA PRODUCCIÓN DE CAFÉ

MANEJO DE DIAGNOSTICO PARATRIOZA EN SOLANACEOS

MANEJO DE ENFERMEDADES EN CAFÉ

MANEJO DE ENFERMENDADES Y PLAGAS DE FRUTALES Y MUSACEAS

MANEJO DE FERTILIZANTES EN CULTIVO DE FRIJOL

MANEJO DE FRIJOL

MANEJO DE HIJOS Y MANEJO DE SOMBRA EN CAFÉ

MANEJO DE HORTALIZAS Y EQUIPOS DE FUMIGACION.

MANEJO DE INVERNADERO

MANEJO DE LA CALIDAD Y PRODUCCION

MANEJO DE LA FERTILIDAD DEL SUELO EN LOS SISTEMAS AGROFORESTALES

MANEJO DE LA LOMBRICULTURA

MANEJO DE LOMBRICULTURA (ALIMENTACIÓN Y COSECHA )

MANEJO DE MINICENTRAL DE BENEFICIO HÚMEDO DE CAFÉ DE COOPLANFLORES

MANEJO DE PARATRIOZA

MANEJO DE PLAGA Y ENFERMEDADES EN EL CUTLIVO DE FRIJOL

MANEJO DE PLAGAS Y ENFERMEDADES CON TECNOLOGIA ORGÁNICA

MANEJO DE PLAGAS Y ENFERMEDADES DEL CULTIVO DE FRIJOL.

MANEJO DE PLAGAS Y ENFERMEDADES E IDENTIFICACION DE DEFICIENCIAS NUTRICIONALES

MANEJO DE PLAGAS Y ENFERMEDADES EN CULTIVO DE FRIJOL Y MAIZ

MANEJO DE PLAGAS Y ENFERMEDADES EN EL CAFÉ

MANEJO DE PLAGAS Y ENFERMEDADES EN EL CAFÉ CON TECNOLOGIA ORGANICA

MANEJO DE PLAGAS Y ENFERMEDADES EN EL CULTIVO DE FRIJOL

MANEJO DE PLAGAS Y ENFERMEDADES Y ESTIMADO DE COSECHA EN CAFÉ

MANEJO DE POST COSECHA DE R \& T

MANEJO DE POST-COSECHA

MANEJO DE PRODUCTOS BIOLÓGICOS AGRITRADE

MANEJO DE PROGRAMA FRÍJOL NICA

MANEJO DE PROGRAMA FRÍJOL NICA

MANEJO DE SOMBRA,DESHIJA Y FERTILIZACIÓN DE CAFÉ

MANEJO DE SOMBRA,DESHIJA Y FERTILIZACIÓN DE CAFÉ

MANEJO DE SOMBRA,DESHIJA Y FERTILIZACIÓN DEL CAFÉ

MANEJO DE TEJIDO DE CACAO

MANEJO DE TEJIDO DEL CACAO

MANEJO DE TEJIDO EN CACAO

MANEJO DE TEJIDO EN CAFÉ

MANEJO DE TEJIDO EN CAFÉ

MANEJO DE TEJIDOS

MANEJO DE TEJIDOS CAFÉ

MANEJO DE TEJIDOS EN CACAO

MANEJO DE TEJIDOS EN CAFÉ

MANEJO DE TEJIDOS EN EL CULTIVO DE CAFÉ

MANEJO DE TEJIDOS EN EL RUBRO CAFÉ.

MANEJO DE VIRUS Y BACTERIAS FITOPATIGENAS Y USO DE FERTILIZANTES FOLIARES

MANEJO DE VIVEROS

MANEJO DE ZANJAS DE FERTILIDAD EN CULTIVO FRUTALES

MANEJO DEL BENEFICIADO HÚMEDO

MANEJO DEL CACAO

MANEJO DEL CICLO DE LA CHICHARRA O GALLINA CIEGA

MANEJO DEL CULTIVO CACAO

MANEJO DEL CULTIVO DE CHILE

MANEJO DEL CULTIVO DEL PLÁTANO,COSTOS DE PRODUCCIÓN Y USO DEL PERSUAP

MANEJO FITOPROTECCION EN CULTIVO DE CALALA

MANEJO FITOSANITARIO CULTIVO DE FRIJOL

MANEJO FITOSANITARIO DE CULTIVO DE FRIJOL

MANEJO FITOSANITARIO DE CULTIVO/MALANGA

MANEJO FITOSANITARIO DE CULTIVO/PAPAYA

MANEJO FITOSANITARIO DEL CULTIVO DE PAPA

MANEJO FITOSANITARIO DEL CULTIVO/PLÁTANO

MANEJO FITOSANITARIO EN CULTIVO DE PAPA Y REPOLLO

MANEJO FITOSANITARIO EN QUEQUISQUE

MANEJO FITOSANITARIO/ESTANDARES/CALIDAD EN R\&T

MANEJO FRIJOL 
MANEJO INTEGRADO DE CULTIVOS

MANEJO INTEGRADO DE PLAGAS

MANEJO INTEGRADO DE PLAGAS (AGROECOLOGIA DEL CULTIVO DEL CACAO)

MANEJO INTEGRADO DE PLAGAS (MIP)

MANEJO INTEGRADO DE PLAGAS EN CACAO

MANEJO INTEGRADO DE PLAGAS EN EL CULTIVO DE LA CANELA

MANEJO INTEGRADO DE PLAGAS EN EL CULTIVO DE LA CANELA.

MANEJO INTEGRADO DE PLAGAS USO DE REGISTROS

MANEJO INTEGRADO DE PLAGAS.

MANEJO INTEGRADO DE PLAGAS/CULTIVOS HORTICOLAS

MANEJO INTEGRADO DEL CULTIVO DE LA PAPA.

MANEJO INTEGRADO FITOSANITARIO PARA MANEJO DE MILDIO VELLOSA EN CULTIVO DE CHAYOTE

MANEJO INTEGRAL DE PLAGAS (MIP)

MANEJO INTELIGENTE DE AGROQUIMICOS

MANEJO INTELIGENTE DE AGROQUIMICOS.

MANEJO INTREGADO DE PLAGAS FUNCIONAMIENTO AGROECOLOGICO DE LOS SISTEMA AGROFORESTALES

MANEJO NUTRICIONAL DEL CULTIVO DE YUCA Y QUEQUISQUE.

MANEJO NUTRICIONAL EN QUEQUISQUE LILA.

MANEJO ORGÁNICO DE PLANTACIONES DE CACAO

MANEJO POSCOSECHA Y RESP/SOCIAL/EMPRESARIAL

MANEJO POST - COSECHA DE GRANOS ALMACENADOS

MANEJO PREVENTIVO EN MELÓN Y TOMATE.

MANEJO PREVENTIVO EN TOMATE

MANEJO TECNIFICADO DEL CULTIVO DE FRIJOL PRODUCCIÓN ARTESANAL DE SEMILLA

MANEJO Y CONTROL DE ENFERMEDADES EN EL CULTIVO DEL CACAO

MANEJO Y CONTROL DE MONILIASIS EN CACAO

MANEJO Y CONTROL DE PLAGAS

MANEJO Y COSECHA DE ABONOS ORGÁNICOS

MANEJO Y REPRODUCCIÓN DEL CULTIVO DE PIMIENTA NEGRA.

MANEJO, MANTENIMIENTO Y CALIBRACION DE DESPULPADORAS

MANEJO/DESECHOS/SOLIDOS Y LIQUIDOS/PRODUCCIÓN DE CAFÉ

MANEJO/INTEGRAL DEL CULTIVO DE FRIJOL

MANEJO/INTEGRAL/REPOLLO/LECHUGA

MANEJO/VIVERO/PLANIFICACION/REPOBLACION DE CAFÉ

MANTENIMIENTO Y CALIBRACIÓN DE EQUIPO

MARCO/CONCEPTUAL/METODOLOGIA/PLANES DE ACCION

MEDIO AMBIENTE

MEDIO AMBIENTE VIII

MEJORAMIENTO DE LA NUTRICION DE LAS PLANTACIONES DE CACAO

MEJORAMIENTO DE LA NUTRICIÓN DE LAS PLANTACIONES DE CACAO

MEJORAMIENTO DE LA NUTRICIÓN DE LAS PLANTACIONES DE CACAO EN SISTEMA AGROFORESTAL

MEJORAMIENTO DE LA NUTRICIÓN DE LAS PLANTACIONES DE CACAO.

MEJORAMIENTO GENETICO DE LAS PLANTACACIONES DE CACAO

MEJORAMIENTO GENETICO DE LAS PLANTACIONES DE CACAO

MEJORAMIENTO GENETICO DE LAS PLANTACIONES DE CACAO

MEJORAMIENTO GENETICO DE LAS PLANTACIONES DE CACAO

MEJORAMIENTO GENETICO DE LAS PLANTACIONES DE CACO

MEJORAMIENTO GENETICO DE LAS PLANTACIONES DE DE CACAO

MEJORAMIENTO GENETICO DEL CACAO

MEJORAMIENTO GENETIO DE LAS PLANTACIONES DE CACAO

MEJORAMIENTO NUTRICIONAL EN HORTALIZAS

MENEJO DE VIRUS Y BACTERIAS FITOPATIGENAS Y USO DE FERTILIZANTES FOLIARES

MESA NACIONAL DE CACAO

MESA NACIONAL DE CACAO

METODO COSECHA CAFE EN PARCELAS VALIDACION

METODO COSECHA PARCELAS VALIDACION

METODOLOGIA DE PROMOTORIA RURAL

METODOLOGIA PROMOTORAS RURALES

METODOLOGIA VALIDACION EN PRE SECADORES

MICRORGANISMO EFICIENTES

MIP CULTIVO FRIJOL

MODELOS DE PRODUCCION DE CACAO

MONTAJE EXPERIMENTOS

MUESTREO DE PLAGAS DE SUELO Y PREPARACION DE CEBOS

MUSTREO DE PLAGAS Y USO DE TRAMPAS

NEGOCIO SEMILLA DE FRIJOL NEGRO Y PROGRAMA FRIJOL NICA

NEGOCIO SEMILLA DE FRIJOL ROJO Y PROGRAMA FRIJOL NICA

NUTRICIÓN DE CAFÉ

NUTRICIÓN DE CAFÉ CON ENFASIS EN REDUCCIÓN DE COSTOS

NUTRICIÓN DEL CULTIVO DE QUEQUISQUE Y EFECTO DE BIOCONTROLADORES EN EL CONTROL DE MAL SECO.

$80 \mid \mathrm{P}$ a g e 
NUTRICION EN EL CULTIVO DE PIÑA MD-2

NUTRICION EN FRIJOL

NUTRICIÓN EN PLÁTANO Y PAPAYA CON PRODUCTOS HIDROSOLUBLES

NUTRICION FOLIAR BIOFERME

NUTRICION FOLIAR DEL CAFE

NUTRICION FOLIAR VEGETAL PROD. BIOFERME

NUTRICION FOLIAR Y NUEVOS PRODUCTOS

NUTRICION VEGETAL DE AGROBONAFIDE

NUTRICION VEGETAL EN CULTIVOS DE HORTALIZAS

NUTRICION VEGETAL EN MUSACEAS

NUTRICION VEGETAL EN TOMATE Y CEBOLLA AMARRILLA

OCRA TOXINA EN EL CAFÉ

PARTICIPACION EN ESPACIOS DE CONSULTAS CIUDADANA

PARTICIPACION EN FERIA DE APEN

PARTICIPACIÓN EN FERIA EN HONOR AL DÍA DE LOS HUMEDALES PARA PROMOVER PRODUCTOS

AGROFORESTALES

PASANTILLA EN BENEFICIO SECO

PASOS PARA UN CULTIVO IDEAL

PLAGAS CUARENTENADAS Y PROBLEMAS CON BACTERIAS

PLAGAS Y ENFERMEDADES DEL QUEQUISQUE SU CONTROL CON EL USO DE BIOCONTROLADORES Y NUTRICION DEL MISMO.

PLAGAS Y ENFERMEDADES DEL QUEQUISQUE SU CONTROL CON EL USO DE BIOCONTROLADORES Y NUTRICIÓN DEL MISMO.

PLAGAS Y ENFERMEDADES DEL QUEQUISQUE, SU CONTROL CON EL USO DE BIOCONTROLADORES.

PLAGAS Y ENFERMEDADES DEL TOMATE

PLAGAS Y ENFERMEDADES EN QUEQUISQUE.

PLAGUICIDAS

PLAN ESTRATEGICO DE LA COOP LAS NUBES

PLAN ESTRATEGICO DE LA COOPERATIVA EL CHIMBORAZO

PLAN MANEJO TEJIDO DE CAFETOS PARCELAS VALIDACIÓN

PLANES DE FINCA

PLANES DE FINCA

PLANIFICACION DE ECA

PLANIFICACION DE FINCA

PLANIFICACION DE FINCAS

PLANIFICACIÓN TRABAJO VALIDACIÓN ENMIENDAS MINERALES

PODA DE CAFÉ Y ELABORACION DE ABONOS ORGANICOS

PODA EN CACAO

PODA EN EL TOMATE

PODA Y MANEJO DE CACAO

POLITICA DE CREDITO Y REQUISITOS FRIJOL PRIMERA

POST COSECHA EN CULTIVO DE MALANGA

PRACTICA DE INSPECCIÓN INTERNAS POR INSPECTORES EN FINCAS EN PROCESO ORGÁNICO

PRACTICAS DE MANEJO POSTCOSECHA EN PLATANO

PREPARACIÓN DE MATERIAL PARA DIA DE CAMPO.

PREPARACION DE MERMELADA DE PIÑA.

PREPARACIÓN DE SUELO PARA SEGUNDA ECA.

PREPARACION Y APLICACION CALDOS MINERALES PARA EL CULTIVO DEL CAFÉ

PREPARCION DE ABONOS ORGANICO

PRESENTACIÓN DE MANUAL BPA EN TOMATE

PRESENTACION DE PRODUCTOS QUIMICOS CON EPA PARA PROD DE GRANOS Y HORTALIZAS

PRESENTACION DE PROGRAMA DE SORGO ESCOBERO

PRESENTACIÓN DEL PROGRAMA FRIJOL NICA - COOPERATIVA ECOLÓGICA 15 DE MAYO.

PRESENTACIÓN LEY DE FOMENTO A LA PRODUCCIÓN AGROECOLOGICA Y ORGÁNICA DE NICARAGUA

PRESENTACIÓN PROGRAMA FRIJOL NICA

PRESENTACION RESULTADOS PRESECADORES SOLARES

PRINCIPIOS DE PRODUCCION

PROCEDIMIENTOS ADMINISTRATIVOS PARA LA CONSTRUCCION DE BENEFICIOS HUMEDOS Y LEY DEL AGUA

PROCESO DE INSPECCIÓN INTERNA EN FINCAS ORGÁNICAS DE LAS FAMILIAS DE COOPROCAFUC

PROCESO DE INSPECIÓN INTERNA Y EXTERNA A GRUPOS DE CAFÉ ORGANICO

PROCESO DE MAQUILA DE FRIJOL

PROCESOS DE CERTIFICACIÒN ORGÀNICA

PRODUCCION , USO DE ABONO ORGÁNICOS

PRODUCCIÓN AGRICOLA EN MANEJO Y ENFERMA EN CULTIVO DE FRIJOL

PRODUCCION ARTESANAL DE SEMILLA DE FRIJOL

PRODUCCIÓN ARTESANAL DE SEMILLA DE FRIJOL

PRODUCCIÓN ARTESANAL FRIJOL

PRODUCCION ARTESANAL SEMILLA FRIJOL RIEGO, SISTEMAS AGROFORESTALES (S.A.F)

PRODUCCION DE MALANGA

PRODUCCIÓN DE MARACUYÁ

PRODUCCION DE PLANTULAS (GRUPO DE MUJERES QUE TRABAJA EN INVERNADERO SAN NICOLAS) 
PRODUCCION DE PLANTULAS BAJO INVERNADERO

PRODUCCIÓN DE PLÁTULAS EN BANDEJAS

PRODUCCIÓN FRIJOL EN RIEGO

PRODUCCION ORGANICA

PRODUCCIÓN SEMILLA DE MALANGA

PRODUCCIÓN Y COMERCIALIZACIÓN DE SEMILLA

PRODUCCIÓN Y USO DE ABONO ORGÁNICO

PRODUCCION/SEMILLA DE FRIJOL

PRODUCCIÓNDE MALANGA

PRODUCION DE PLANTULAS BAJO INVERNADEROS

PRODUCTOS ECOLOGICOS

PRODUCTOS ORGANICOS

PROGRAMA DE FRIJOL NICA

PROMOCIÓN DE RAICES Y TUBERCULOS

PROPUESTA BAYER DE SANIDAD Y FITOPROTECCION PARA EL CULTIVO DE PAPA

PRUEBAS PRACTICAS DE FERTILIDAD DE SUELO

RAICES ENFASIS EN PLAGAS Y ENFERMEDADES

RAICES Y TUBERCULOS

RAICES Y TUBERCULOS

RAÍCES Y TUBERCULOS

RECONOCIENDO INSECTOS EN HORTALIZAS.

RECONOCIMIENTO DE ENFERMEDADES

RECONOCIMIENTO DE ENFERMEDADES FUNGOSAS

RECUENTO DE PLAGAS

RECUENTO DE PLANTAS AFECTADAS POR HONGOS

REGULACION DE SOMBRA

REPLICA DE TALLER ADA

REPRODUCCIÓN DE PLÁNTULAS

REPRODUCCIÓN DEL CACAO

REQUISITOS Y REGISTROS BPA

RIEGO Y FERTILIZACION EN FRUTALES Y MUSACEAS

SELECCIÓN Y DESINFECCIÓN DE SEMILLA DE MALANGA

SIEMBRA DE FRIJOL Y DENSIDAD POBLACIONAL

SIEMBRA DEL CULTIVO TOMATE, ECA

SISTEMA DE SIEMBRA DE ZANAHORIA

SISTEMA INTERNO DE CONTROL PARA CERTIFICACION FINCAS CACAO CRIOLLO

SISTEMA INTERNO DE CONTROL/ CERTIFICACION ORGANICA

SISTEMA/RIEGO/GOTEO

SISTEMAS AGROFORESTALES (SAF)

SISTEMAS DE PRODUCCION EFICIENTE

SISTEMAS DE PRODUCCION EFICIENTE EN HORTALIZAS

SISTEMAS DE RIEGO POR GOTEO

TALLER "BUENAS PRACTICAS AGRICOLAS"

TALLER CON MODADLIDAD ESCUELA DE CAMPO SOBRE MEJORAMIENTO GENETICO DEL CACAO

TALLER CON MODALIAD ESCUELA DE CAMPO SOBRE MANEJO INTEGRADO DE PLAGAS EN LAS

PLANTACIONES DE CACAO

TALLER CON MODALIAD ESCUELA DE CAMPO SOBRE MANEJO INTEGRADO DE PLAGAS EN LAS

PLANTACIONES DE CACAO

TALLER CON MODALIAD ESCUELA DE CAMPO SOBRE MEJORAMIENTO DE LA NUTRICIÓN DE LAS

PLANTACIONES DE CACAO

TALLER CON MODALIDA ESCUELA DE CAMPO SOBRE MEJORAMIENTO GENETICO DEL CACAO

TALLER CON MODALIDAD ECAS EN MANEJO INTEGRADO DE PLAGAS EN CACAO

TALLER CON MODALIDAD ESCUELA DE CAMPO MEJORAMIENTO GENETICO DEL CACAO

TALLER CON MODALIDAD ESCUELA DE CAMPO SOBRE MANEJO INTEGRADO DE PLAGAS EN CACAO

TALLER CON MODALIDAD ESCUELA DE CAMPO SOBRE MEJORAMIENTO GENETICO DEL CACAO

TALLER CON MODALIDAD ESCUELA DE CAMPO SOBRE EN MANEJO INTEGRADO DE PLAGAS

TALLER CON MODALIDAD ESCUELA DE CAMPO SOBRE ESTABLECIMIENTO Y MANEJO DE VIVEROS DE

CACAO

TALLER CON MODALIDAD ESCUELA DE CAMPO SOBRE MANEJO INTEGRADO DE PLAGAS EN CACAO

TALLER CON MODALIDAD ESCUELA DE CAMPO SOBRE MEJORAMIENTO DE LA NUTRICIÓN DE LAS

PLANTACIONES DE CACAO

TALLER CON MODALIDAD ESCUELA DE CAMPO SOBRE MEJORAMIENTO DE LA NUTRICIÓN DE LAS

PLANTACIONES DE CACAO

TALLER CON MODALIDAD ESCUELA DE CAMPO SOBRE MEJORAMIENTO GENETICO DEL CACAO

TALLER CON MODALIDAD ESCUELA DE CAMPO SOBRE MEJORAMIENTO GÉNETICO DEL CACAO

TALLER CON MODALIDAD ESCUELA DE CAMPO SOBRE MEJORAMIENTO GÉNETICO DEL CACAO.

TALLER CON MODALIDAD ESCUELO DE CAMPO SOBRE MANEJO INTEGRADO DE PLAGAS EN CACAO

TALLER DE CERTIFICACIÓN ORGANICA SOBRE ACTUALIZACIÓN DE LAS NORMAS DE PRODUCCIÓN

ORGANICA INTERNA DE COOPROCAFUC R,L

TALLER DE CERTIFICACIÓN ORGANICA SOBRE LA EVALUACION DEL PLAN DE PRODUCCION 2010 Y ACTUALIZACION DE DOCUMENTOS EN CERTIFICACION ORGANICA 
TALLER DE CERTIFICACIÓN ORGANICA SOBRE LA PLANIFICACIÓN DEL PLA DE DE PRODUCCIÓN ORGANICA 2011.

TALLER DE CERTIFICACIÓN ORGANICA SOBRE NORMA PARA LA AGRICULTURA SOSTENIBLE.

TALLER DE CERTIFICACIÓN ORGANICA SOBRE PLANIFICACIÓN DEL PLAN DE PRODUCCIÓN ORGANICA 2011 TALLER DE GRUPOS FOCALES DE MUJERES EN TRANSFORMACION Y COMERCIALIZACION DE CACAO Y PIMIENTA

TALLER DE METODOLOGÍA PARA EL DISEÑO Y FACILITACIÓN DE EVENTOS EDUCATIVOS

TALLER DE PRODUCCION DE PLANTULAS

TALLER DE PRODUCCIÓN DE SEMILLA DE MALANGA CON CALIDAD

TALLER DE REVISION DE COSTOS DE PRODUCCION EN EL CULTIVO DE TOMATE

TALLER MANEJO DE PLAGAS Y ENFERMEDADES

TALLER METODOLOGÍA DE CAPACITACIÓN

TALLER METODOLOGÍA DE CAPACITACIÓN

TALLER MODALIDAD ESCUELA DE CAMPO / MEJORAMIENTO GENETIO DE LAS PLANTACIONES DE CACAO

TALLER MODALIDAD ESCUELA DE CAMPO / MEJORAMIENTO GENETICO DE LAS PLANTACACIONES DE

CACAO

TALLER MODALIDAD ESCUELA DE CAMPO / MEJORAMIENTO GENETICO DE LAS PLANTACIONES DE CACAO TALLER MODALIDAD ESCUELA DE CAMPO / MEJORAMIENTO GENETICO DE LAS PLANTACIONES DE CACO TALLER MODALIDAD ESCUELA DE CAMPO / MEJORAMIENTO GENETICO DE LAS PLANTACIONES DE DE CACAO

TALLER POST COSECHA CULTIVO DE MALANGA

TALLER REGIONAL SOBRE ZEBRA CHIP Y SU VECTOR EN EL CULTIVO DE TOMATE

TALLER SISTEMAS DE RIEGO POR GOTEO

TALLER SOBRE COSECHA Y CONTROL DE CALIDAD DE CACAO

TALLER SOBRE CULTIVO DE RAICES

TALLER SOBRE DIAGNOSTICO FITOSANITARIIO

TALLER SOBRE DIAGNOSTICO FITOSANITARIO COMO BASE DEL MANEJO INTEGRADO DE PLAGAS

TALLER SOBRE DIAGNOSTICO FITOSANITARIO DE LAS PLANTACIONES DE CACAO.

TALLER SOBRE ELABORACIÓN DE ABONOS ORGANICOS.

TALLER SOBRE ESTABLECIMIENTO DE CACAO EN SISTEMAS AGROFORESTALES

TALLER SOBRE ESTABLECIMIENTO DE CACAO EN SISTEMAS AGROFORESTALES.

TALLER SOBRE ESTRUCTURA DE COSTO DE PRODUCCIÓN DEL CULTIVO DE CACAO.

TALLER SOBRE EVALUACIÓN DE CAMBIO MÁS SIGNIFICATIVOS LOGRADOS A TRAVÉS DEL PROYECTO EN

LAS ESCUELAS DE CAMPO.

TALLER SOBRE FERTILIZACIÓN DE CACAO

TALLER SOBRE LA IMPORTANCIA DEL CULTIVO DE RAICES.

TALLER SOBRE LLENADO DE FORMATOS PARA CERTIFICACION ORGANICA

TALLER SOBRE MANEJO DE LA NUTRICIÓN EN LAS PLANTACIONES DE CACAO.

TALLER SOBRE MANEJO DE NITRONAT

TALLER SOBRE MANEJO DE RAÍCES CON ENFASIS EN FERTILIZACIÓN ORGÁNICA

TALLER SOBRE MANEJO INTEGRADO DE PLAGAS

TALLER SOBRE MEJORAMIENTO DE LA NUTRICION DE LAS PLANTACIOES DE CACAO

TALLER SOBRE MEJORAMIENTO DE LA NUTRICIÓN DE LAS PLANTACIONES DE CANELA.

TALLER SOBRE MEJORAMIENTO GENETICO DEL CACAO.

TALLER SOBRE PARATRIOZA

TALLER SOBRE PARATRIOZA II

TALLER SOBRE PLANIFICACION DE SIEMBRA Y PROYECCION DE COSECHA EN EL RUBRO FRIJOL

HORTALIZAS

TALLER SOBRE PLANIFICACION DE SIEMBRA Y PROYECCION DE COSECHA EN EL RUBRO DE FRIJOL Y

HORTALIZAS

TALLER SOBRE PLANIFICACIÓN DEL PLAN DE PRODUCCIÓN ORGANICA 2012

TALLER SOBRE PLANIFICACIÓN PLAN DE PRODUCCIÓN ORGANICA 2012.

TALLER SOBRE PRACTICAS DE MANEJO PARA MEJORAR LA PRODUCTIVIDAD DE LA CANELA.

TALLER SOBRE PRACTICAS DE MANEJO PARA MEJORAR LA PRODUCTIVIDAD EN EL CULTIVO DE CANELA TALLER SOBRE PRÁCTICAS DE MANEJO PARA MEJORAR LA PRODUCTIVIDAD EN EL CULTIVO DE CANELA TALLER SOBRE REPRODUCCIÓN DE LA PIMIENTA NEGRA.

TALLER SOBRE SUSTANCIAS TÓXICAS

TALLER USO DE INOCULANTES PARA FRIJOL (BACTERIA RHYZOBIUM)

TALLER/FISIOLOGÌA VEGETAL Y NECECIDAD VEGETATIVA/CAFÈ

TALLER: PILOTO DE FRÍJOL EN GESTIÓN DEL CONOCIMIENTO

TALLER: PILOTO DE FRÍJOL EN GESTION DEL CONOCIMIENTO EN LA EMPRESA APODER

TALLER: SEGUROS AGRÍCOLAS Y PRESENTACIÓN DE FLO-CERT

TÉCNICAS DE INJERTO EN VIVERO DE CACAO

TECNOLOGÍA DE PRODUCCIÓN DE FRIJOL PARA EXPORTACIÓN.

TECNOLOGÍAS DE NUTRICIÓN ESPECIALIZADAS PARA LA PRODUCTIVIDAD DE FRIJOL Y MAÍZ.

TIPO DE PDA Y MANEJO DE PLAGAS Y ENFERMEDADES

TRASPLANTE EN EL CULTIVO DE TOMATE.

TRATAMIENTO Y MANEJO DE AGUAS MIELES

TRIPLE LAVADO DE ENVASES QUIMICO

USO DE INSECTISIDAS Y PRACTICAS DE MANEJO/ NO QUEMA

USO DE BIOCONTROLADORES EN CULTIVOS DE QUEQUISQUE Y PIÑA. 
USO DE CALDOS MINERALES PARA EL MANEJO INTEGRADO FITOSANITARIO PARA MILDIU, VELLOSO EN CULTIVO DE CHAYOTE

USO DE CALDOS, MINERALES Y BIOFERTILIZANTES

USO DE CONTROLADORES BIOLOGICOS

USO DE CUADERNO DE CAMPO

USO DE INOCULANTES EN SEMILLA DE FIJOL PARA MEJORAR RENDIMIENTOS

USO DE INSECTIDAS NATURALES

USO DE NITRONAT EN CULTIVO DE FRIJOL

USO DE PLANTULAS PARA LA PROD. DE HORTALIZAS

USO DE SISTEMAS DE RIEGO PARA PRODUCCIÓN DE FRIJOL

USO DEL PLASTICO MULCH

USO SEGURO DE BIOPLAGUICIDAS

USO SEGURO DE PLAGUICIDAS

USO Y ESTABLECIMIENTO DE TRAMPAS AMARILLAS Y AZULES

USO Y MANEJO NUTRICIONAL DE CULTIVOL DE FRIJOL

USO Y MANEJO DE AGROQUIMICOS

USO Y MANEJO DE AGUA PARA LA PRODUCCION

USO Y MANEJO DE INOCULANTE NITRONAT EN CULTIVO DE FRIJOL

USO Y MANEJO DE NITRONAT EN EL CULTIVO DE FRIJOL

USO Y MANEJO DE PROD.QUIMICOS

USO Y MANEJO DE SUELOS PARA LA AGRICULTURA Y SELECCIÓN DE CRITERIOS INDICADORES PARA MEDIR

LA FERTILIZACION DE LOS SUELOS

USO Y MANEJO DE TRICHODERME Y BEAUBERIA EN LA AGRICULTURA.

USO Y MANEJO DEL PAQUETE FITOSANITARIO DE FRIJOL NICA

USO Y MANEJO SEGURO DE PLAGUICIDAS

USO Y MENEJO DE INOCULANTE PARA FRIJOL NOTRONAT

VALIDACIÓN DE 10 VARIEDADES DE PAPA

VALIDACION DE CARTA TECNOLOGICA/CAFÉ

VALIDACION DE CARTA TECNOLOGICA/MALANGA

VALIDACION DE COSTOS DE CACAO

VALIDACION DE COSTOS DE CAFÉ

VALIDACION TECNOLOGIA EN PRE-SECADORES SOLARES

VALIDACIÓN TECNOLOGÍA ENMIENDAS MINERALES

VALOR AGREGADO

VALORACION PRODUCTIVA DEL CAFÉ Y VARIEDADES ALTERNATIVAS

VENTAJAS DE LA PREPARACIÓN DE SUELO.

VENTAJAS DE LOS SISTEMAS DE RIEGO

VENTAJAS DEL MUETREO DE PLAGAS.

VIAJE DE INTERCAMBIO (ALAJUELA, SAN JOSE, HEREDIA Y CARTAGO - COSTA RICA)

VIAJE DE INTERCAMBIO DE EXPERIENCIAS CON AGRICULORES A PAÑAS BLANCAS-COSTA RICA

VIDA EN EL SUELO

VIDA EN EL SUELO Y ELABORACIÓN DE BIOFERTILIZANTE EN LA COMUNIDAD

VIDA EN EL SUELO Y ELABORACIÓN DE BIOFERTILIZANTE EN LA COMUNIDAD

VISITA DE INTERCAMBIO DE EXPERIENCIA EN MANEJO DE FRIJOL DE RIEGO

AGRICULTURA ORGÁNICA

BUENAS PRACTICAS DE MANUFACTURAS

BUENAS PRACTICAS DE MANUFACTURAS EN RAICES Y TUBERCULOS

CERTIFICACIÓN DE FINCAS

CERTIFICACIÓN Y COMERCIO JUSTO

CONSTRUCCION DE BENEFECIO ECOLÓGICO

CONTROL DE ENFERMEDADES Y MANEJO POST COSECHA EN FRIJOL

CONTROL DE PLAGAS Y ENFERMEDADES PARA CAFÉ EN DESARROLLO

DIAGNOSTICOS PRIORIZACIÓN DE RUBROS

DISEÑO E INSTALACION DE SISTEMAS DE RIEGO POR GOTEO

EXPERIENCIA EN MANEJO AGRONOMICO DE PRODUCCION DE SEMILLA DE FRIJOL

FERTILIDAD Y FERTILIZACIÓN

FERTILIDAD Y FERTILIZACIÓN DE SUELOS

FERTILIZACION FOLIAR EN HORTALIZAS

GIRA A PLANTA DE MALANGA

GIRA DE CAMPO

GIRA DE CAMPO CULTIVO DE FRIJOL SEMILLA Y COMERCIAL

GIRA DE CAMPO PRODUCCION DE SEMILLA

GIRA DE INTERCAMBIO CENTRO PRODUCCION DE PLANTULAS EN SANTA CLARA

GIRA DE INTERCAMBIO CON PRODUCTORES DE SOMOTO, PUEBLO NUEVO Y MOZONTE EN SEBACO-CARRETA QUEBRADA

GIRA DE INTERCAMBIO DE EXP. CON PROD. DE YALI EN MANEJO DE AREAS DE PROD DE SEMILLA DE FRIJOL

GIRA DE INTERCAMBIO DE EXPERIENCIA

GIRA DE INTERCAMBIO PARA VISITA A PARCELAS DE CHILE PICANTE

INTERCAMBIO DE EXPERIENCIAS CON PRODUCTORES DE SOMOTO, MOZONTE Y PUEBLO NUEVO. PARA

SIEMBRA DE CHILE

INTERCAMBIO DE EXPERIENCIAS RAÍCES Y TUBERCULOS

84 | P a g e 
INTERCAMBIO DE EXPERIENICIA SOBRE PRODUCCIÓN Y COMERCIALIZACIÓN DE CHILE TABASCO, ABANERO Y CAYENE

MANEJO AGRONOMICO DE MALANGA

MANEJO DE CONTROL DE BABOSAS EN CULTIVO DE FRIJOL

MANEJO DE ENFERMEDADES EN CAFETALES

MANEJO FITOSANITARIO DE FRIJOL

MANEJO POST COSECHA EN FRIJOL

MANEJO Y PRODUCCION DE SEMILLA CERTIFICADA DE FRIJOL

NUTRICION FOLIAR MILAGRO EN CULTIVO DE FRIJOL

PRESENTACION DE DIFERENTES PRODUCTOS (MILAGRO)

PRIMER ENCUENTRO DE PRODUCTORES DE CEBOLLA DE JINOTEGA

PRIORIZACIÓN DE RUBROS

PRODUCCIÓN ARTESANAL DE SEMILLA DE FRIJOL

RECOMOCIMIENTO DE PLAGAS Y ENFERMEDADES DEL CULTIVO DE FRIJOL

SEGUIMIENTO PARCELAS DE MALANGA

TALLER DE MANEJO INTEGRADO DE PLAGAS

TALLER DE MANEJO POST-COSECHA

TALLER MANEJO DE POSTCOSECHA

TALLER MANEJO INTEGRADO DE PLAGAS

TRAZABILIDAD E INOCUIDAD DE LOS PRODUCTOS

USO DEL RIEGO

\subsubsection{Environmental Program}

\section{Water}

ADMINISTRACIÓN DE SISTEMAS DE AGUA POTABLE RURALES.

AGUA POTABLE Y SALUD PREVENTIVA

AGUA POTABLE Y SANEAMIENTOS

AGUA SEGURA PARA TODOS

AGUA Y SANEAMIENTO

AGUA Y SANEAMIENTOS

AGUA Y SANIAMIENTO

APROBECHAMIENTO DE OBRAS DE CONSERVACION DE SUELO Y AGUA PARA LA CERTIFICACIÓN

BENEFICIADO HUMEDO Y EL BUEN USO DEL AGUA

BUEN USO DEL AGUA PARA LA PRODUCCIÓN

BUEN USO DEL AGUA PARA LA PRODUCCIÓN Y LEY GENERAL DE AGUA 620

BUENAS PRACTICA AGRICOLAS

BUENAS PRACTICAS PARA EVITAR CONTAMINACIÓN DEL AGUA

CAPACITACIÓN A COMITÉ DE AGUA POTABLE

CAPACITACIÓN A COMITES DE AGUA POTABLE Y SANEAMIENTO

CAPACITACION EN DISEÑO Y ESTABLECIMIENTO DE PRACTICAS DE CONSERVACION DE SUELOS Y AGUAS

CAPACITACION EN GENERO Y CALIDAD DE AGUA

CHARLA DE USO Y MANEJO DE AGUA PARA CONSUMO DOMESTICO Y USO ADECUADO DEL FILTRO

COMITÉ DE AGUA POTABLE / CAPS LEY 722

COMITÉ DE AGUA POTABLE / CAPS LEY 723

COMITÉ DE AGUA POTABLE / CAPS LEY 724

COMITÉ DE AGUA POTABLE / CAPS LEY 725

COMITÉ DE AGUA POTABLE / CAPS LEY 726

CONCEPTOS BASICOS DE GENERO Y MEDIO AMBIENTE

CONOCER Y APROBAR REGLAMENTOS DEL CAPS

CONSERVACIÓN DE LAS FUENTES DE AGUA/JORNADA DE LIMPIEZA

CONSERVACIÓN DE SUELO

CONSERVACIÓN DE SUELO Y AGUA

CONSERVACION DE SUELOS

CONSULTA PRESUPUESTARIA

CONSULTA PRESUPUESTARIA MUNICIPAL

CONSULTA PRESUPUESTARIA MUNICIPAL

DESARROLLO DEL PROESO DE CONSULTA COMUNITARIA

DIA DE CAMPO EN CONSERVACIÓN DE SUELO Y AGUA (C.S.A)

ESTABLECIMIENTO DE OBRAS DE CONCERVACION DE SUELOS Y AGUAS

GENERO Y CALIDAD DE AGUA

GENERO Y MEDIO AMBIENTE

GÉNERO Y MEDIO AMBIENTE

GIRA DE INTERCAMBIO DE CONOCIEMIENTOS EN MANEJO DE AGUA

GIRA DE INTERCAMBIO MEJORES PRACTICAS PARA EL MANEJO DE AGUA

GIRA DE INTERCAMBIO SOBRE COSERVACION DE SUELO

GIRA DE INTERCAMBIO SOBRE OBRAS DE CONSERVACIÓN DE SUELOS Y AGUAS

GIRA INTERCAMBIO SOBRE OBRAS DE CONSERVACIÓN DE SUELOS Y AGUAS

GIRA SOBRE CONSERVACIÓN DE SUELO Y AGUA (CSA) 
HABITOS DE HIGIENE AMBIETAL, PERSONAL Y DE LOS ALIMENTOS.

HIGIENE ALIMENTOS, PERSONAL Y AMBIENTAL

HIGIENE AMBIENTAL, HIGIENE PERSONAL E HIGIENE DE LOS ALIMENTOS

HIGIENE DE LOS ALIMENTOS

HIGIENE DE PERSONAL, HIGIENE DE LOS ALIMENTOS E HIGIENE AMBIENTAL

HOGARES SALUDABLE

HOGARES SALUDABLES

HOGARES SALUDABLES

INTERCAMBIO ENTRE PRODUCTORES DE COMISIONES DE EDUCACION SOBRE LEY AMBIENTAL.

INTERCAMBIO ENTRE PRODUCTORES Y TECNICOS SOBRE LEY AMBIENTAL

INTERCAMBIO ENTRE TECNICOS Y PRODUCTORES EN EL BUEN USO DEL AGUA.

INTERCAMBIO TECNICO EN TEMA LEY AMBIENTAL

INTERCAMBIO TECNICO LEY AMBIENTAL

INVERCIONES DEL GOBIERNO LOCAL Y LAS DEMANDAS DEL SECTOR PÚBLICO

LEY ESPECIAL DELITOS CONTRA EL MEDIO AMBIENTE Y RECURSOS NATURALES

LEY 40

LEY 620 LEY DE AGUA (FUNCIONAMIENTO DE LOS APS)

LEY AMBIENTAL Y USO SEGURO DE PLAGUICIDAS

LEY BASICA PARA REGULACION Y CONTROL DE PLAGUISIDAS LEY 274

LEY COMITÉ DE AGUA Y SANEAMIENTO / CAPS

LEY DE AGUA

LEY DE AGUA Y LEY DE LOS CAPS

LEY DE AGUA, LEY DE CAPS

LEY DE LOS COMITÉ DE AGUA POTABLE

LEY DE MEDIO AMBIENTE Y LEY DE PLAGUICIDAS

LEY DE MEDIO AMBIENTE Y LOS RECURSOS NATURALES

LEY DE MEDIO AMBIENTE Y RECURSOS NATURALES

LEY DE PALGUICIDAS (LEY 274)

LEY DE PLAGUICIDAS

LEY DE PLAGUICIDAS Y MEDIO AMBIENTE

LEY DE PLAGUICIDAS Y MEIO AMBIENTE

LEY DE PLAGUICIDAS, SUSTANCIAS TOXICAS OTRAS

LEY DEL AGUA

LEY DEL AGUA Y PROTECCION DE FUENTES HIDRICAS

LEY ESPECIAL DE AGUA Y CAPS

LEY GENERAL DE AGUA 620 PARA LA PRODUCCIÓN

LEY GENERAL DE AGUAS NACIONALES

LEY GENERAL DE AGUAS NACIONALES Y PROTECCIÓN DE FUENTES HÍDRICAS

LEY GENERAL DE PLAGUISIDAS

LEY GENERAL DEL MEDIO AMBIENTE Y SUS REFORMAS /COMPONENTE AGUA

MANEJO DE AGUA DE CONSUMO

MANEJO DE AGUA DE CONSUMO DOMESTICO/HUMANO

MANEJO DE AGUA DE COSUMO Y RIEGO

MANEJO DE AGUA PARA CONSUMO DOMESTICO

MANEJO DE AGUA PARA CONSUMO DOMESTICO

MANEJO DE AGUA PARA LA PRODUCCIÓN

MANEJO DE AGUA PARA USO DOMÉSTICO (ACUEDUCTO RURAL)

MANEJO DE OBRAS DE CONSERVACIÓN DE SUELOS Y AGUA

MANEJO DE PLAGUICIDAS

MANEJO DE PRODUCCIÓN DE PESTICIDAS EN BODEGAS

MANEJO DEL AGUA PARA CONSUMO DOMESTICO

MANEJO DEL AGUA PARA CONSUMO HUMANO

MANEJO USO DE AGUA DE CONSUMO DOMESTICO

MANEJO Y PROTECCIÓN DEL RECURSO AGUA.

MANEJO Y SOSTENIBILIDAD DE LOS SISTEMAS DE AGUA POTABLE, CALIDAD DE AGUA.

MANEJO Y USO AGUA DE CONSUMO

MANEJO Y USO DE AGUA PARA CONSUMO HUMANO

MANEJO Y USO DE PLAGUICIDAS

METODOLOGIA PARA LA CONSTRUCCIÓN DE DIQUES

METODOS Y TECNICAS PARA DESINFECTAR AGUA DE CONSUMO

OBRA DE AGUA (RETENCION) Y USO RACIONAL DEL AGUA

ORDENANZA MUNICIPAL

PLAN DE MANEJO FORESTAL

PROCEDIMIENTO PARA CONTROL DE AGUA EN EL CENTRO DE ACOPIO C.Q

PROTECCIÓN Y CONSERVACIÓN DE LAS FUENTES DE AGUA

REFORESTACIÓN DE AREA CON FUENTES DE AGUA

REFORESTACIÓN EN ÁREAS CON FUENTES DE AGUA

REFORESTACION EN FUENTES DE AGUA

REGLAMENTTO DE LOS CAPS, CONFORMACIÓN DE LOS CAPS

SALUD PREVENTIVA Y CALIDAD DE AGUA

SALUD PREVENTIVA Y CALIDAD DE AGUA.

$86 \mid \mathrm{P}$ a g e 
SANEAMIENTO SOBRE AGUA POTABLE

SECIÓN DE REFLEXIÓN AGUA Y SANEAMIENTO

SESIÓN DE REFLEXIÓN AGUA Y SANEAMIENTO

SUMINISTRO DE AGUA Y SANEAMIENTO E HIGIENE DE LOS CAPS.

TALLER DE SEGUIMIENTO A LOS CAPS

TALLER SOBRE LEGALIZACIÓN DE LOS CAPS

TALLER AGUA PARA LA PRODUCCION

TALLER BUENAS PRACTICAS AGRICOLAS

TALLER COMITE DE AGUA POTABLE

TALLER DE HIGIENE Y SALUD DE LOS ALIMENTOS

TALLER FAMILIA SALUDABLE (ENFERMEDADES EL CÓLERA, LA INFLUEZA HUMANA, LA GRIPE, LA

DIARREA, LECTOSPIROSIS)

TALLER LEGALIZACIÓN DE LOS CAPS

TALLER MANEJO DE AGUA

TALLER MANEJO DE AGUA DE CONSUMO

TALLER SESIÓN DE REFLEXIÓN AGUA Y SANIAMIENTO

TALLER SOBRE HIGIENE DE LOS ALIMENTOS, PERSONAL Y AMBIENTAL.

TALLER SOBRE LEYES DE FUNCIONAMIENTOS DE LOS CAPS

TALLER: MANEJO SANITARIO Y BUEN USO DEL AGUA

TECNICAS DE POTABILIZACIÓN DE AGUA

TECNICAS EN MANEJO DE AGUA

USO DE MANEJO DE COCINAS PELUCERAS

USO EFICIENTE Y AHORRO DEL AGUA

USO Y CONSUMO DE AGUA DE PRODUCCIÓN

USO Y MANEJO DE AGUA

USO Y MANEJO DE AGUA EN LA PRODUCCIÓN

USO Y MANEJO DE AGUA PARA CONSUMO

USO Y MANEJO DE AGUA POTABLE

USO Y MANEJO DE CONSUMO DE AGUA DOMESTICA

USO Y MANEJO DE COSINAS PELUCERAS

USO Y MANEJO DE PLAGUICIDAS

USO Y MANEJO DE PLAGUICIDAS EN BODEGAS

USO Y MANEJO DE SISTEMAS AGROFORESTALES

VIAJE DE INTERCAMBIO PARA MEJORAR MANEJO DE AGUA TECNICAS DE MANEJO DE AGUA

ADMINISTRACIÓN DE SISTEMAS DE AGUA POTABLE RURALES.

AGUA POTABLE Y SALUD PREVENTIVA

AGUA POTABLE Y SANEAMIENTOS

AGUA SEGURA PARA TODOS

AGUA Y SANEAMIENTO

AGUA Y SANEAMIENTOS

AGUA Y SANIAMIENTO

APROBECHAMIENTO DE OBRAS DE CONSERVACION DE SUELO Y AGUA PARA LA CERTIFICACIÓN

BENEFICIADO HUMEDO Y EL BUEN USO DEL AGUA

BUEN USO DEL AGUA PARA LA PRODUCCIÓN

BUEN USO DEL AGUA PARA LA PRODUCCIÓN Y LEY GENERAL DE AGUA 620

BUENAS PRACTICA AGRICOLAS

BUENAS PRACTICAS PARA EVITAR CONTAMINACIÓN DEL AGUA

CAPACITACIÓN A COMITÉ DE AGUA POTABLE

CAPACITACIÓN A COMITES DE AGUA POTABLE Y SANEAMIENTO

CAPACITACION EN DISEÑO Y ESTABLECIMIENTO DE PRACTICAS DE CONSERVACION DE SUELOS Y AGUAS

CAPACITACION EN GENERO Y CALIDAD DE AGUA

CHARLA DE USO Y MANEJO DE AGUA PARA CONSUMO DOMESTICO Y USO ADECUADO DEL FILTRO

COMITÉ DE AGUA POTABLE / CAPS LEY 722

COMITÉ DE AGUA POTABLE / CAPS LEY 723

COMITÉ DE AGUA POTABLE / CAPS LEY 724

COMITÉ DE AGUA POTABLE / CAPS LEY 725

COMITÉ DE AGUA POTABLE / CAPS LEY 726

CONCEPTOS BASICOS DE GENERO Y MEDIO AMBIENTE

CONOCER Y APROBAR REGLAMENTOS DEL CAPS

CONSERVACIÓN DE LAS FUENTES DE AGUA/JORNADA DE LIMPIEZA

CONSERVACIÓN DE SUELO

CONSERVACIÓN DE SUELO Y AGUA

CONSERVACION DE SUELOS

CONSULTA PRESUPUESTARIA

CONSULTA PRESUPUESTARIA MUNICIPAL

CONSULTA PRESUPUESTARIA MUNICIPAL

DESARROLLO DEL PROESO DE CONSULTA COMUNITARIA

DIA DE CAMPO EN CONSERVACIÓN DE SUELO Y AGUA (C.S.A)

ESTABLECIMIENTO DE OBRAS DE CONCERVACION DE SUELOS Y AGUAS

GENERO Y CALIDAD DE AGUA

GENERO Y MEDIO AMBIENTE 
GÉNERO Y MEDIO AMBIENTE

GIRA DE INTERCAMBIO DE CONOCIEMIENTOS EN MANEJO DE AGUA

GIRA DE INTERCAMBIO MEJORES PRACTICAS PARA EL MANEJO DE AGUA

GIRA DE INTERCAMBIO SOBRE COSERVACION DE SUELO

GIRA DE INTERCAMBIO SOBRE OBRAS DE CONSERVACIÓN DE SUELOS Y AGUAS

GIRA INTERCAMBIO SOBRE OBRAS DE CONSERVACIÓN DE SUELOS Y AGUAS

GIRA SOBRE CONSERVACIÓN DE SUELO Y AGUA (CSA)

HABITOS DE HIGIENE AMBIETAL, PERSONAL Y DE LOS ALIMENTOS.

HIGIENE ALIMENTOS, PERSONAL Y AMBIENTAL

HIGIENE AMBIENTAL, HIGIENE PERSONAL E HIGIENE DE LOS ALIMENTOS

HIGIENE DE LOS ALIMENTOS

HIGIENE DE PERSONAL, HIGIENE DE LOS ALIMENTOS E HIGIENE AMBIENTAL

HOGARES SALUDABLE

HOGARES SALUDABLES

HOGARES SALUDABLES

INTERCAMBIO ENTRE PRODUCTORES DE COMISIONES DE EDUCACION SOBRE LEY AMBIENTAL.

INTERCAMBIO ENTRE PRODUCTORES Y TECNICOS SOBRE LEY AMBIENTAL

INTERCAMBIO ENTRE TECNICOS Y PRODUCTORES EN EL BUEN USO DEL AGUA.

INTERCAMBIO TECNICO EN TEMA LEY AMBIENTAL

INTERCAMBIO TECNICO LEY AMBIENTAL

INVERCIONES DEL GOBIERNO LOCAL Y LAS DEMANDAS DEL SECTOR PÚBLICO

LEY ESPECIAL DELITOS CONTRA EL MEDIO AMBIENTE Y RECURSOS NATURALES

LEY 40

LEY 620 LEY DE AGUA (FUNCIONAMIENTO DE LOS APS)

LEY AMBIENTAL Y USO SEGURO DE PLAGUICIDAS

LEY BASICA PARA REGULACION Y CONTROL DE PLAGUISIDAS LEY 274

LEY COMITÉ DE AGUA Y SANEAMIENTO / CAPS

LEY DE AGUA

LEY DE AGUA Y LEY DE LOS CAPS

LEY DE AGUA, LEY DE CAPS

LEY DE LOS COMITÉ DE AGUA POTABLE

LEY DE MEDIO AMBIENTE Y LEY DE PLAGUICIDAS

LEY DE MEDIO AMBIENTE Y LOS RECURSOS NATURALES

LEY DE MEDIO AMBIENTE Y RECURSOS NATURALES

LEY DE PALGUICIDAS (LEY 274)

LEY DE PLAGUICIDAS

LEY DE PLAGUICIDAS Y MEDIO AMBIENTE

LEY DE PLAGUICIDAS Y MEIO AMBIENTE

LEY DE PLAGUICIDAS, SUSTANCIAS TOXICAS OTRAS

LEY DEL AGUA

LEY DEL AGUA Y PROTECCION DE FUENTES HIDRICAS

LEY ESPECIAL DE AGUA Y CAPS

LEY GENERAL DE AGUA 620 PARA LA PRODUCCIÓN

LEY GENERAL DE AGUAS NACIONALES

LEY GENERAL DE AGUAS NACIONALES Y PROTECCIÓN DE FUENTES HÍDRICAS

LEY GENERAL DE PLAGUISIDAS

LEY GENERAL DEL MEDIO AMBIENTE Y SUS REFORMAS /COMPONENTE AGUA

MANEJO DE AGUA DE CONSUMO

MANEJO DE AGUA DE CONSUMO DOMESTICO/HUMANO

MANEJO DE AGUA DE COSUMO Y RIEGO

MANEJO DE AGUA PARA CONSUMO DOMESTICO

MANEJO DE AGUA PARA CONSUMO DOMESTICO

MANEJO DE AGUA PARA LA PRODUCCIÓN

MANEJO DE AGUA PARA USO DOMÉSTICO (ACUEDUCTO RURAL)

MANEJO DE OBRAS DE CONSERVACIÓN DE SUELOS Y AGUA

MANEJO DE PLAGUICIDAS

MANEJO DE PRODUCCIÓN DE PESTICIDAS EN BODEGAS

MANEJO DEL AGUA PARA CONSUMO DOMESTICO

MANEJO DEL AGUA PARA CONSUMO HUMANO

MANEJO USO DE AGUA DE CONSUMO DOMESTICO

MANEJO Y PROTECCIÓN DEL RECURSO AGUA.

MANEJO Y SOSTENIBILIDAD DE LOS SISTEMAS DE AGUA POTABLE, CALIDAD DE AGUA.

MANEJO Y USO AGUA DE CONSUMO

MANEJO Y USO DE AGUA PARA CONSUMO HUMANO

MANEJO Y USO DE PLAGUICIDAS

METODOLOGIA PARA LA CONSTRUCCIÓN DE DIQUES

METODOS Y TECNICAS PARA DESINFECTAR AGUA DE CONSUMO

OBRA DE AGUA (RETENCION) Y USO RACIONAL DEL AGUA

ORDENANZA MUNICIPAL

PLAN DE MANEJO FORESTAL

PROCEDIMIENTO PARA CONTROL DE AGUA EN EL CENTRO DE ACOPIO C.Q

$88 \mid \mathrm{P}$ a g e 
PROTECCIÓN Y CONSERVACIÓN DE LAS FUENTES DE AGUA

REFORESTACIÓN DE AREA CON FUENTES DE AGUA

REFORESTACIÓN EN ÁREAS CON FUENTES DE AGUA

REFORESTACION EN FUENTES DE AGUA

REGLAMENTTO DE LOS CAPS, CONFORMACIÓN DE LOS CAPS

SALUD PREVENTIVA Y CALIDAD DE AGUA

SALUD PREVENTIVA Y CALIDAD DE AGUA

SANEAMIENTO SOBRE AGUA POTABLE

SECIÓN DE REFLEXIÓN AGUA Y SANEAMIENTO

SESIÓN DE REFLEXIÓN AGUA Y SANEAMIENTO

SUMINISTRO DE AGUA Y SANEAMIENTO E HIGIENE DE LOS CAPS.

TALLER DE SEGUIMIENTO A LOS CAPS

TALLER SOBRE LEGALIZACIÓN DE LOS CAPS

TALLER AGUA PARA LA PRODUCCION

TALLER BUENAS PRACTICAS AGRICOLAS

TALLER COMITE DE AGUA POTABLE

TALLER DE HIGIENE Y SALUD DE LOS ALIMENTOS

TALLER FAMILIA SALUDABLE (ENFERMEDADES EL CÓLERA, LA INFLUEZA HUMANA, LA GRIPE, LA

DIARREA , LECTOSPIROSIS)

TALLER LEGALIZACIÓN DE LOS CAPS

TALLER MANEJO DE AGUA

TALLER MANEJO DE AGUA DE CONSUMO

TALLER SESIÓN DE REFLEXIÓN AGUA Y SANIAMIENTO

TALLER SOBRE HIGIENE DE LOS ALIMENTOS, PERSONAL Y AMBIENTAL.

TALLER SOBRE LEYES DE FUNCIONAMIENTOS DE LOS CAPS

TALLER: MANEJO SANITARIO Y BUEN USO DEL AGUA

TECNICAS DE POTABILIZACIÓN DE AGUA

TECNICAS EN MANEJO DE AGUA

USO DE MANEJO DE COCINAS PELUCERAS

USO EFICIENTE Y AHORRO DEL AGUA

USO Y CONSUMO DE AGUA DE PRODUCCIÓN

USO Y MANEJO DE AGUA

USO Y MANEJO DE AGUA EN LA PRODUCCIÓN

USO Y MANEJO DE AGUA PARA CONSUMO

USO Y MANEJO DE AGUA POTABLE

USO Y MANEJO DE CONSUMO DE AGUA DOMESTICA

USO Y MANEJO DE COSINAS PELUCERAS

USO Y MANEJO DE PLAGUICIDAS

USO Y MANEJO DE PLAGUICIDAS EN BODEGAS

USO Y MANEJO DE SISTEMAS AGROFORESTALES

VIAJE DE INTERCAMBIO PARA MEJORAR MANEJO DE AGUA TECNICAS DE MANEJO DE AGUA

\section{Environmental management}

BPA ETA`S, EFECTOS DE PLAGUICIDAS EN LA SALUD, Y REGISTROS E INFRAESTRUCTURAS BASICA CAMBIO CLIMATICO

CAMBIO CLIMATICO ENFOCADO A CAFÉ

CAMBIO CLIMATICO Y CALENTAMIENTO GLOBAL

CAPACITACION A PROMOTORES EN CAMBIO CLIMATICO, MEDIO AMBIENTE SEGURIDAD E HIGIENE

COCIENCIA AMBIENTAL

CONSTRUCCION, USO Y MANEJO DE BIODIGESTORES

DISEÑO Y MANEJO DE BIODIGESTORES TUBULARES PLASTICOS

EFECTO Y MANEJO DE SUSTANCIAS TÓXICAS

ELABORACIÓN DE PLAN DE MITIGACIÓN AMBIENTAL.

EQUIPOS DE PROTECCIÓN PARA LA APLICACIÓN DE PESTICIDAS

FERIA ECOLOGICA

FORO AMBIENTAL

HIGIENE AMBIENTAL Y SALUD PREVENTIVA

III FERIA-FORO DEL CACAO DE LA RESERVA DE BIOSFERA DE R.S.J.

IMPORTANCIA DE EQUIPOS DE PROTECCION Y CALIBRACION DE EQUIPOS.

INTERCAMBIO DE EXPERIENCIA MANEJO DE LETRINAS CON BIODIGESTORES

JORNADA ECOLOGICA

LEY BASICA PARA LA REGULACION Y CONTROL DE PLAGUICIDAS Y LEY DEL MEDIO AMBIENTE

LEY PROTECCIÓN MEDIO AMBIENTE

LLL FERIA FORO DEL CACAO DE LA RESERVA BIOSFERA DE CACAO EN RIO SAN JUA

MANEJO DE PLAGUICIDAS Y SUSTANCIA TOXICAS

MEDIO AMBIENTE / PREVENCIÓN CONTRA INCENDIOS FORESTALES.

MEDIO AMBIENTE: AGUA Y RECURSOS NATURALES

PILOTAJE SERVICIOS AMBIENTALES

PRESENTACION DE MANUAL DE ORIENTACION SOBRE USO RESPONSABLE DE AGROQUIMICOS Y PROGRAMA CAMPO LIMPIO 
PRESENTACIÓN DE RESULTADOS DE PRESECADORES SOLARES A INSTITUCIONES REFORESTACION DE BOSQUES (MUNICICPALISMO) REFORESTACION Y MANEJO DE BOSQUES PARA PROTECCION DE MEDIO AMBIENTE SISTEMA DE EVALUACIÓN AMBIENTAL

TALLER AMBIENTAL

TALLER AMBIENTAL

TALLER DE MANEJO DE PLAGUICIDAS Y SUSTANCIAS TOXICAS

TALLER MANEJO DE PLAGUICIDAS Y SUSTANCIA TÓXICAS

TALLER MEDIO AMBIENTE, INCENDIOS FORESTALES

TALLER MEDIOAMBIENTAL

TALLER SOBRE CAMBIO CLIMATICOS

TALLER SOBRE DELITOS AMBIENTALES

TALLER SOBRE EL MANEJO DE SUSTANCIAS TOXICAS

TALLER SOBRE LOS EFECTOS DEL CAMBIO CLIMATICO EN EL CULTIVO DEL CACAO

TALLER SOBRE PREVENCIÓN DE INCENDIOS FORESTALES

TALLER USO Y MANEJO DE PLAGUICIDAS / GÉNERO

TIS, CAPTACION DIOXIDO DE CARBONO

USO DE AGROQUIMICOS Y MANEJO PRODUCTIVO DE FRÍJOL

USO DEL TRICHOMAX Y ELABORACIÓN DEL PLAN DE MITIGACIÓN.

USO Y MANEJO DE BIODIGESTORES

USO Y MANEJO DE BIOPLAGUICIDAS

\subsubsection{Gender Program}

ATENCIÓN MEDICA EN LA COMUNIDAD

AUTO ESTIMA

AUTOESTIMA Y GÉNERO

AUTOESTIMA Y LIDERAZGO

AUTOESTIMA, LIDERAZGO Y TOMA DE DECISIONES

CADENA DE VALOR DE LA PAPA, CON ENFOQUE DE GÉNERO

CAPACITACIÓN SOBRE AUTOESTIMA Y GÉNERO

CAPACITACIÓN SOBRE GÉNERO Y CALIDAD DE AGUA.

CINE FORO DE CUIDO PERSONAL

COMUNICACIÓN NO VIOLENTA

CONCEPTUALIZACIÓN DE LA ESTRATEGIA DE GENERO

CONCEPTUALIZACIÓN DE LA ESTRATEGIAS DE GENERO

CONSTRUCCIÓN DE LA POLITICA DE GENERO

COOPERATIVISMO Y GÉNERO

COORDINACIÓN DEL FUNCIONAMIENTO DEL GRUPO DE MUJERES EN LA COMERCIALIZACIÓN DE LA CANELA CUIDO PERSONAL

DAR A CONOCER LA ESTRATEGIA DE GÉNERO DEL PROYECTO ACORDAR

DAR A CONOCER LA POLITICA DE GÉNERO DEL PROYECTO ACORDAR

DESARROLLO EMPRERSARIAL CON EQUIDAD DE GENERO

DESARROLLO EMPRESARIAL CON EQUIDAD DE GENERO

DESARROLLO EMPRESARIAL Y GENERO

DESARROLLO EMPRESARIAL Y GÉNERO

DESARROLLO HUMANO Y AUTOESTIMA

DESIMINACIÓN DE LAS POLITICAS DE GENERO

DISEMINACIÓN DE LA POLITICA DE GENERO

DISEMINACIÓN DE LA POLÍTICA DE GÉNERO

DISEMINACION DE LAS POLITICAS Y ESTRATEGIAS DE GENERO

DISEMINACIÓN DE POLITICA DE GÉNERO

DISEMINACION DE POLITICAS Y ESTRATEGIAS DE GENERO

DISEMINACION E IMPLEMENTACION DE POLITICAS Y ESTRATEGIA DE GENERO CON DIRECTIVOS

DIVULGACION DE POLITICA DE GENERO ACORDAR EN CECOOPSEMEIN

ELABORACIÓN POLÍTICAS DE GÉNERO Y MEDIO AMBIENTE

ENCUENTRO ANUAL DE MUJERES

EQUIDAD DE GENERO

EQUIDAD DE GENERO EN CADENAS DE VALOR DE R\&T

ESTRETAGIA DE GÉNERO DEL PROYECTO ACORDAR

EVALUACIÓN Y MONITOREO DE INDICADORES DE GENERO

FORO: CADENAS DE VALOR CON ROSTRO DE MUJER

FORTALECIMIENTO DE LAS CAPACIDADES PARA UNA ASESORIA TECNICA CON ENFOQUE DE GENERO

GENERO

GÉNERO Y AUTOESTIMA

GENERO Y BPA

GENERO Y BUENAS PRACTICAS AGRICOLAS

GÉNERO Y CALIDAD DE AGUA

GÉNERO Y LIDERAZGO

GÈNERO Y MEDIO AMBIENTE

GRUPO FOCAL SISTEMATIZACION GENERO

$90 \mid \mathrm{P}$ a g e 
IDENTIDAD DE GÉNERO

IMPLEMENTACION DE POLITICA DE GENERO EN GRUPOS DE MUJERES PRODUCTORAS DE ABONO ORGANICO LOMBRIHUMUS

INTERCAMBIO CON ORGANIZACIONES SOCIAS DE FLO EN EL PROCESO DE PILOTAJE DE INDICADORES DE GENERO

LIDERAZGO

LIDERAZGO EMPRESARIAL Y GÉNERO.

LIDERAZGO Y AUTOESTIMA

MONITOREO Y EVALUACIÓN DE LOS INDICADORES DE GÉNERO (ENCUENTRO CON PROMOTORAS)

PARTICIPACION EN FERIA SOBRE EQUIDAD DE GENERO (PRESENTACION DE GRUPOS DE MUJERES

PRODUCTORAS DE LOMBRIHUMUS Y PRESENTACION DE BANDEJAS DE PLANTULAS

PARTICIPACION EN TALLER: DISEÑO Y FACILITACION DE EVENTOS EDUCATIVOS, DIRIGIDOS A MUJERES

SOCIAS DE COOPERATIVAS (EDUCACION POPULAR)

PARTICIPACIÓNEN ENCUENTRO DEPARTAMENTAL DE PROMOTORAS EN GÉNERO

POLITICA DE GENERO

POLITICAS DE GÉNERO Y MEDIO AMBIENTE

PRESUPUESTOS Y FLUJOS DE CAJA

PRIMER FORO DE GÉNERO

PRINCIPIOS DE LIDERASGO Y MOTIVACION

PROTECCION, SALUD E HIGIENE AMBIENTAL Y DEL AGUA

PSICOLOGIA DE RELACIONES HUMANAS

RELACIONES HUMANAS

SALUD PREVENTIVA Y ATENCION MEDICA

TALLER DE CONSULTA PARA LA ELABORACIÓN POLITICA DE GENERO

TALLER A GRUPO DE MUJERES SOBRE DESARROLLO EMPRESARIAL

TALLER AUTOESTIMA

TALLER DE GENERO

TALLER DE GENERO SOBRE BUENA COMUNICACIÓN Y TOMA DE DECISIONES

TALLER DE LIDERAZGO EMPRESARIAL PARA INTEGRAR MUJERES A LAS COOPERATIVAS

TALLER DE LIDERAZGO EMPRESARIAL Y GENERO

TALLER DESARROLLO EMPRESARIAL Y GENERO

TALLER PARTICIPATIVO DE CONSULTA PARA LA ELABORACIÓN DE LA POLÍTICA DE GÉNERO.

TALLER PARTICIPATIVO DE GÉNERO. FORMULACION POLITICAS

TALLER PARTICIPATIVO PARA ELABORACION DE POLITICAS DE GENERO Y MEDIO AMBIENTE

TALLER PARTICIPATIVO PARA ELABORAR POLÍTICA DE GÉNERO Y MEDIO AMBIENTE DE COMULSAN

TALLER PARTICIPATIVO SOBRE GÉNERO Y MEDIO AMBIENTE

TALLER SOBRE CAMBIO MAS SIGNIFICATIVO A MUJERES DE COOPERATAIVAS DE BASE

TALLER SOBRE DISEMINACIÓN DE LAS POLITICAS DE GENERO

TALLER SOBRE FORMULACIÓN DE ESTRATEGIA DE TRABAJO DE GRUPO DE MUJERES DE CANELA

TALLER: GÉNERO Y LIDERAZGO

VIOLENCIA INTRAFAMILIAR

CONCEPTUALIZACIÓN DE GÉNERO

\subsubsection{Post-harvest Program}

\section{Manufacturing practices}

MANIPULADORES DE ALIMENTOS

MANUAL DE BPM Y CALIDAD Y SUS ANEXOS (PROCEDIMIENTOS, INSTRUCTIVOS Y REGISTROS)

USO DE EXTINTORES

\section{Post-harvest management}

ALMACENAMIENTO Y MANEJO DE GRANOS

CALCULO E IDENTIFICACION DE PARAMETROS DE CALIDAD DE FRIJOL

CAPACITACION SOBRE PROCESO DE ACOPIO, FERMENTO, SECADO Y CALIDA DEL CACAO.

COSECHA Y POSTCOSECHA DE LAS PLANTACIONES DE CANELA

CRITERIOS PARA CUANTIFICAR LA CALIDAD DE FRIJOLES

DEMOSTRACION DE PARAMETROS DE FRIJOL NEGRO

ECA - WISCOYOL; COSECHA Y DÍA DE CAMPO.

INSTALACION DE PLASTICO EN PRE SECADOR

INTERCAMBIO DE EXPERIENCIA EN COSECHA Y POST-COSECHA EN CANELA

INTERCAMBIO EXPERIENCIA PRESECADOR ARTESANAL

MANEJO DE CALIDAD EN LA COSECHA Y POST-COSECHA DE CACAO

MANEJO DE CALIDAD EN LA COSECHA Y POST-COSECHA DEL CACAO

MANEJO DE LA CALIDAD DEL CACAO EN LOS PROCESOS DE COSECHA Y POST COSECHA

MANEJO DE LA CALIDAD EN LA COSECHA Y POST COSECHA DEL CACAO.

MANEJO DE LA CALIDAD EN LA COSECHA Y POSTCOSECHA DE CACAO

MANEJO DE LA CALIDAD EN LA COSECHA Y POSTCOSECHA DEL CACAO

MANEJO DE LA CALIDAD EN LOS PROCESOS DE COSECHA Y POST COSECHA DE CACAO. 
MANEJO DE LA CALIDAD EN LOS PROCESOS DE COSECHA Y POST COSECHA DEL CACAO. MANEJO DE LA CALIDAD EN LOS PROCESOS DE COSECHA Y POSTCOSECHA DEL CACAO MANEJO DE POSTCOSECHA DE CACAO

MANEJO FITOSANITARIO

MANEJO POS- COSECHA

MANEJO POSCOSECHA DE PAPAYA E INTRODUCCION A LAS BPA

MANEJO POST COSECHA

MANEJO POST COSECHA DE CACAO

MANEJO POST COSECHA DE CACAO

MANEJO POST COSECHA DE CULTIVO DE TOMATE Y MANEJO DE PARATRIOZA

MANEJO POST COSECHA DE FRIJOL

MANEJO POST COSECHA DE GRANOS

MANEJO POST COSECHA DEL CACAO

MANEJO POST COSECHA EN EL CULTIVO DE FRIJOL

MANEJO POST COSECHA EN EL CULTIVO DE MALANGA

MANEJO POST COSECHA EN GRANOS BASICOS

MANEJO POST COSECHA EN PLATANO

MANEJO POST COSECHA EN SEMILLA DE FRIJOL

MANEJO POST COSECHA, HORTALIZAS Y GRANOS BASICOS EN FINCAS BPA

MANEJO POSTCOSECHA

MANEJO POSTCOSECHA DE FRIJOL

MANEJO POST-COSECHA DE FRÍJOL CON PRODUCTORES DE LA ORGANIZACIÓN APODER.

MANEJO POST-COSECHA EN CULTIVO DE CEBOLLA

MANEJO POST-COSECHA EN CULTIVO DE QUEQUISQUE.

MANEJO POSTCOSECHA EN HORTALIZAS Y GRANOS BASICOS

MANEJO POSTCOSECHA Y PARAMETROS PARA ACOPIO DE FRIJOL SEMILLA Y COMERCIAL

POS COSECHA

POSCOSECHA EN GRANOS BASICOS, PRUEBA DE HUMEDAD

POST COSECHA DE CULTIVO DE FRIJOL

POST COSECHA EN CACAO

POST COSECHA EN EL CULTIVO DE CACAO

POST COSECHA EN HORTALIZAS

POST COSECHA FRIJOL

POST-COSECHA DE HORTALIZAS

POSTCOSECHA EN CULTIVO DE FRIJOL

POST-COSECHA Y PROCESAMIENTO DE SEMILLA DE FRIJOL.

PRACTICAS DE CORTE DE CHILOTE

PRESENTACION RESULTADOS BENEFICIADO HUMEDO CAFE Y PRESECADORES SOLARES

TALLER DE COSECHA Y MANEJO POST-COSECHA DE LA CANELA

TALLER EN ENTRENAMIENTO EN SERVICIO TEORICO-PRACTICO SOBRE POSTCOSECHA EN CACAO

TALLER MANEJO POSTCOSECHA DE FRIJOL

TALLER POSTCOSECHA CULTIVO DE FRIJOL

TALLER POSTCOSECHA EN EL CULTIVO DE MALANGA

TALLER SOBRE COSECHA Y POST COSECHA DE LAS PLANTACIONES DE CANELA

TALLER SOBRE IMPLEMENTACIÓN DE LA RED DE ACOPIOS COMUNALES PARA GARANTIZAR LA

COMERCIALIZACIÓN DEL CACAO.

TALLER SOBRE LEVANTAMIENTO DE ESTIMADOS DE COSECHA

TALLER SOBRE MANEJO DE LA CALIDAD EN LA COSECHA Y POST COSECHA DEL CACAO.

TECNICAS DE MANEJO POSCOSECHA DE CACAO 


\section{References}

Alene, A. D., Manyong, V. M., Omanya, G., Mignouna, H. D., Bokanga, M., \& Odhiambo, G. (2008). Smallholder market participation under transactions costs: Maize supply and fertilizer demand in Kenya. Food Policy, 33(4), 318-328.

Assefa, T. W., \& Minten, B. (2015). Synopsis: Can agricultural traders be trusted? Evidence from urban coffee markets in Ethiopia (ESSP II Research Note No. 36). Washington, D.C. \& Addid Ababa, Ethiopia: International Food Policy Research Institute (IFPRI) \& Ethiopian Development Research Institute (EDRI).

Balat, J., Brambilla, I., \& Porto, G. (2009). Realizing the gains from trade: Export crops, marketing costs, and poverty. Journal of International Economics, 78(1), 21-31.

Barrett, C. B. (1996). Market Analysis Methods: Are Our Enriched Toolkits Well Suited to Enlivened Markets? American Journal of Agricultural Economics, 78(3), 825-829.

Barrett, C. B. (2008). Smallholder market participation: Concepts and evidence from eastern and southern Africa. Food Policy, 33(4), 299-317.

Barrett, C. B., Bachke, M. E., Bellemare, M. F., Michelson, H. C., Narayanan, S., \& Walker, T. F. (2012). Smallholder participation in contract farming: comparative evidence from five countries. World Development, 40(4), 715-730.

Barrett, C. B., Carter, M. R., \& Timmer, C. P. (2010). A Century-Long Perspective on Agricultural Development. American Journal of Agricultural Economics, 92(2), 447-468.

Barrett, C. B., \& Swallow, B. M. (2006). Fractal poverty traps. World Development, 34(1), 115.

Baulch, B. (1997). Testing for food market integration revisited. Journal of Development Studies, 33(4), 512-534.

Bellemare, M. F., \& Barrett, C. B. (2006). An Ordered Tobit Model of Market Participation: Evidence from Kenya and Ethiopia. American Journal of Agricultural Economics, 88(2), 324-337.

Berdegué, J. (2002). Learning to beat Cochrane’s treadmill. Public Policy, Markets and Social Learning in Chile's Small-Scale Agriculture. In C. Leeuwis \& R. Pyburn (Eds.), Wheelbarrows Full of Frogs: Social Learning in Rural Resource Management, 333-348.

Berdegué, J. A., Balsevich, F., Flores, L., \& Reardon, T. (2005). Central American supermarkets' private standards of quality and safety in procurement of fresh fruits and vegetables. Private Agri-Food Standards: Implications for Food Policy and Agri-Food Systems, 30(3), 254-269.

Bertrand, M., Duflo, E., \& Mullainathan, S. (2004). How much should we trust differences-indifferences estimates? The Quarterly Journal of Economics, 119(1), 249-275.

Besedeš, T., \& Prusa, T. J. (2011). The role of extensive and intensive margins and export growth. Journal of Development Economics, 96(2), 371-379.

Bignebat, C., \& Vagneron, I. (2011). Cross-border coordination in the Madagascar-EU lychee chain: the role of GlobalGAP. UMR MOISA: Marchés, Organisations, Institutions et Stratégies d'Acteurs: CIHEAM-IAMM, CIRAD, INRA, Montpellier SupAgro, IRDMontpellier, France.

Binswanger, H. P. (1998). Development: Painful Lessons. International Agricultural Development, 287. 
Blundell, R., \& Dias, M. C. (2009). Alternative approaches to evaluation in empirical microeconomics. Journal of Human Resources, 44(3), 565-640.

Boselie, D., Henson, S., \& Weatherspoon, D. (2003). Supermarket procurement practices in developing countries: Redefining the roles of the public and private sectors. American Journal of Agricultural Economics, 85(5), 1155-1161.

Breusch, T. S., \& Pagan, A. R. (1979). A simple test for heteroscedasticity and random coefficient variation. Econometrica: Journal of the Econometric Society, 1287-1294.

Bromley, D. W., \& Chavas, J.-P. (1989). On Risk, Transactions, and Economic Development in the Semiarid Tropics. Economic Development and Cultural Change, 37(4), 719-736.

Carletto, C., Kilic, T., \& Kirk, A. (2011). Nontraditional crops, traditional constraints: The longterm welfare impacts of export crop adoption among Guatemalan smallholders. Agricultural Economics, 42, 61-76.

Carletto, C., Kirk, A., Winters, P. C., \& Davis, B. (2010). Globalization and Smallholders: The Adoption, Diffusion, and Welfare Impact of Non-Traditional Export Crops in Guatemala. Globalization, Poverty, and Inequality in Latin America, 38(6), 814-827.

CETREX. (2015, April 21). Informe de exportaciones al dia. Centro de Trámites de las Exportaciones. Retrieved from http://www.cetrex.gob.ni:7777/reporte/reporte_diario.pdf

Chaney, T. (2008). Distorted Gravity: The Intensive and Extensive Margins of International Trade. The American Economic Review, 98(4), 1707-1721.

Chopra, M., Galbraith, S., \& Darnton-Hill, I. (2002). A global response to a global problem: the epidemic of overnutrition. Bulletin-World Health Organization, 80(12), 952-958.

CIAT. (n.d.). Linking Farmers to Markets | DAPA. Retrieved February 7, 2014, from http://dapa.ciat.cgiar.org/linking-farmers-to-markets/

Codron, J.-M., Siriex, L., \& Reardon, T. (2006). Social and environmental attributes of food products in an emerging mass market: Challenges of signaling and consumer perception, with European illustrations. Agriculture and Human Values, 23(3), 283-297.

COHA. (2010, August 13). Nicaragua \& ALBANISA: The Privatization of Venezuelan Aid. Retrieved October 23, 2014, from http://www.coha.org/nicaragua-albanisa-theprivatization-of-venezuelan-aid/

Collier, P., \& Dercon, S. (2014). African Agriculture in 50 Years: Smallholders in a Rapidly Changing World? Economic Transformation in Africa, 63(0), 92-101.

CRS. (2010). ACORDAR Project: Report on the first phase October 2007 to March 2010 (p. 87). Managua, Nicaragua: Catholic Relief Services.

D’agostino, R. B., Belanger, A., \& D’Agostino Jr, R. B. (1990). A suggestion for using powerful and informative tests of normality. The American Statistician, 44(4), 316-321.

De Janvry, A., Fafchamps, M., \& Sadoulet, E. (1991). Peasant Household Behaviour with Missing Markets: Some Paradoxes Explained. The Economic Journal, 101(409), 14001417.

Dethier, J.-J., \& Effenberger, A. (2012). Agriculture and development: A brief review of the literature. Economic Systems, 36(2), 175-205.

Dillon, B. M., \& Barrett, C. B. (2013). The Impact of World Oil Price Shocks on Maize Prices in East Africa. Working Paper.

Dolan, C. (2001). The "Good Wife": Struggles over Resources in the Kenyan Horticultural Sector. The Journal of Development Studies, 37(3), 39-70.

Dolan, C., \& Humphrey, J. (2000). Governance and Trade in Fresh Vegetables: The Impact of 
UK Supermarkets on the African Horticulture Industry. The Journal of Development Studies, 37(2), 147-176.

Donnet, M. L., Weatherspoon, D. D., \& Hoehn, J. P. (2007). What adds value in specialty coffee? Managerial implications from hedonic price analysis of Central and South American e-auctions. International Food and Agribusiness Management Review, 10(3), $1-18$.

Donnet, M. L., Weatherspoon, D. D., \& Hoehn, J. P. (2008). Price determinants in top-quality eauctioned specialty coffees. Agricultural Economics, 38(3), 267-276.

Donovan, J., \& Poole, N. (2008). Linking Smallholders to Markets for Non-Traditional Agricultural Exports: a Review of Experiences in the Caribbean Basin. AACP Paper Series, 2.

Donovan, J., \& Stoian, D. (2012). 5 Capitals: A Tool for Assessing the Poverty Impacts of Value Chain Development. CATIE.

Escoto, R., Centeno, E., Hernandez, F., \& Angulo, K. (2012). ACORDAR: Ex-Post Performance Evaluation Report.

Fackler, P. L., \& Goodwin, B. K. (2001). Chapter 17 Spatial price analysis. In Bruce L. Gardner and Gordon C. Rausser (Ed.), Handbook of Agricultural Economics (Vol. Volume 1, Part B, pp. 971-1024). Elsevier.

Fafchamps, M. (1993). Sequential Labor Decisions Under Uncertainty: An Estimable Household Model of West-African Farmers. Econometrica, 61(5), 1173-1197.

Fafchamps, M., \& Hill, R. V. (2005). Selling at the farmgate or traveling to market. American Journal of Agricultural Economics, 87(3), 717-734.

Faminow, M. D., \& Benson, B. L. (1990). Integration of Spatial Markets. American Journal of Agricultural Economics, 72(1), 49-62.

FAO. (2012). Análisis de la cadena de valor de frijol rojo y negro en Nicaragua con enfoque de Seguridad Alimentaria y Nutricional. Managua, Nicaragua: FAO.

FAO. (n.d.-a). FAOSTAT. Retrieved December 9, 2014, from http://faostat3.fao.org/faostatgateway/go/to/browse/T/TP/E

FAO. (n.d.-b). Linking farmers to markets - AGS. Retrieved February 7, 2014, from http://www.fao.org/ag/ags/agricultural-marketing-linkages/linking-farmers-to-markets/en/

Farina, E. M. M. Q., \& Reardon, T. (2000). Agrifood Grades and Standards in the Extended Mercosur: Their Role in the Changing Agrifood System. American Journal of Agricultural Economics, 82(5), 1170-1176.

Faye, M., Jooste, A., Lowenberg-DeBoer, J., \& Fulton, J. (2004). The influence of cowpea characteristics on cowpea prices in Senegal. Agrekon, 43(4), 418-429.

Fay, M., \& Morrison, M. (2007). Infrastructure in Latin America and the Caribbean: recent developments and key challenges. World Bank Publications.

Felbermayr, G. J., \& Kohler, W. (2006). Exploring the Intensive and Extensive Margins of World Trade. Review of World Economics, 142(4), 642-674.

Feller, A., Schunk, D., \& Callarman, T. (2006). Value chains versus supply chains. BPTrends, 17.

Frankel, J. A., \& Romer, D. (1999). Does Trade Cause Growth? The American Economic Review, 89(3), 379-399.

Frankel, J., Romer, D., \& Cyrus, T. (1996). Trade and Growth in East Asian Countries: Cause and Effect? (No. w5732). Cambridge, MA: National Bureau of Economic Research. 
Retrieved from http://www.nber.org/papers/w5732.pdf

Getnet, K., Verbeke, W., \& Viaene, J. (2005). Modeling spatial price transmission in the grain markets of Ethiopia with an application of ARDL approach to white teff. Agricultural Economics, 33, 491-502.

Giannakas, K., \& Fulton, M. (2005). Process Innovation Activity in a Mixed Oligopoly: The Role of Cooperatives. American Journal of Agricultural Economics, 87(2), 406-422.

Goetz, S. J. (1992). A Selectivity Model of Household Food Marketing Behavior in SubSaharan Africa. American Journal of Agricultural Economics, 74(2), 444.

Goletti, F., Ahmed, R., \& Farid, N. (1995). Structural determinants of market integration: the case of rice markets in Bangladesh. The Developing Economies, 33(2), 196-198.

Graubner, M., Balmann, A., \& Sexton, R. J. (2011). Spatial price discrimination in agricultural product procurement markets: a computational economics approach. American Journal of Agricultural Economics, 93(4), 949-967.

Gulati, A., Minot, N., Delgado, C., \& Bora, S. (2007). Growth in high-value agriculture in Asia and the emergence of vertical links with farmers. In Global Supply Chains, Standards and the Poor: How the Globalization of Food Systems and Standards Affects Rural Development and Poverty (pp. 91-108). CABI, Wallingford, UK.

Hazell, P., Poulton, C., Wiggins, S., \& Dorward, A. (2010). The Future of Small Farms: Trajectories and Policy Priorities. World Development, 38(10), 1349-1361.

Hellin, J., Lundy, M., \& Meijer, M. (2009). Farmer organization, collective action and market access in Meso-America. Food Policy, 34(1), 16-22.

Hernandez, R., Berdegue, J. A., \& Reardon, T. (2012). Modern Markets and Guava Farmers in Mexico. In 2012 Conference, August 18-24, 2012, Foz do Iguacu, Brazil. International Association of Agricultural Economists.

Hernández, R., Reardon, T., \& Berdegué, J. (2007). Supermarkets, wholesalers, and tomato growers in Guatemala. Agricultural Economics, 36(3), 281-290.

Herrera Mora, E. de F. (2014, April). Informacion Proyecto.

Holzapfel, S., \& Wollni, M. (2014). Is GlobalGAP Certification of Small-Scale Farmers Sustainable? Evidence from Thailand. The Journal of Development Studies, 50(5), 731747.

Humphrey, J. (2009). Private Standards in Kenyan Horticulture: Did the Donors Respond Effectively to the Challenge? In Conference Paper,'Towards Priority Actions for Market Development for African Farmers', sponsored by the International Livestock Research Institute Nairobi.

Humphrey, J., \& Navas-Alemán, L. (2010). Value Chains, Donor Interventions and Poverty Reduction: A Review of Donor Practice. IDS Research Reports, 2010(63), 1-106.

IFAD. (2012, August 27). IFAD to fund value chain programme to link small farmers to markets in Nigeria. Retrieved February 7, 2014, from http://www.ifad.org/media/press/2012/48.htm

IFAD. (n.d.). Rural poverty in Nicaragua. Retrieved May 15, 2015, from http://www.ruralpovertyportal.org/country/home/tags/nicaragua

INIDE. (2011). National Census of Agriculture: 2011 (Census). Nicaragua: Instituto Nacional de Información de Desarrollo.

Jacoby, H. G. (2000). Access to Markets and the Benefits of Rural Roads. The Economic Journal, 110(465), 713-737. 
Jacoby, H. G., \& Minten, B. (2009). On measuring the benefits of lower transport costs. Journal of Development Economics, 89(1), 28-38.

Jaffee, S., Henson, S., \& Diaz Rios, L. (2011). Making the Grade: Smallholder Farmers, Emerging Standards, and Development Assistance Programs in Africa. A Research Program Synthesis. Washington DC: World Bank. Report, (62324-AFR).

Kersting, S., \& Wollni, M. (2012). New institutional arrangements and standard adoption: Evidence from small-scale fruit and vegetable farmers in Thailand. Food Policy, 37(4), 452-462.

Key, N., Sadoulet, E., \& de Janvry, A. (2000). Transactions Costs and Agricultural Household Supply Response. American Journal of Agricultural Economics, 82(2), 245-259.

La Prensa. (2011, April 7). Desplome en exportaciones de frijol. La Prensa. Managua, Nicaragua. Retrieved from http://www.laprensa.com.ni/2014/03/10/activos/185945piden-no-cerrar-fronteras

Li, H., Ma, H., Xu, Y., \& Xiong, Y. (2012). How do exchange rate movements affect Chinese exports? A firm-level investigation (School of Economics and Management No. mimeo). Tsinghua University.

Mabaya, E. (2003). Smallholder agricultural markets in Zimbabwe: Organization, spatial integration and equilibrium. Cornell University, May.

Maertens, M., \& Swinnen, J. F. M. (2007). The fall and rise of vertical coordination in commodity chains in developing and transition countries (Vol. 2, pp. 47-67). Presented at the Trade and Markets Division, Workshop on Governance, Coordination, and Distribution along Commodity Value Chains, Rome: FAO.

Maertens, M., \& Swinnen, J. F. M. (2009). Trade, Standards, and Poverty: Evidence from Senegal. World Development, 37(1), 161-178.

Markelova, H., Meinzen-Dick, R., Hellin, J., \& Dohrn, S. (2009). Collective action for smallholder market access. Collective Action for Smallholder Market Access, 34(1), 1-7.

Mérel, P. R., Sexton, R. J., \& Suzuki, A. (2009). Optimal Investment in Transportation Infrastructure When Middlemen Have Market Power: A Developing-Country Analysis. American Journal of Agricultural Economics, 91(2), 462-476.

Michelson, H. C. (2013). Small farmers, NGOs, and a Walmart World: Welfare effects of supermarkets operating in Nicaragua. American Journal of Agricultural Economics, 95(3), 628-649.

Michelson, H., Reardon, T., \& Perez, F. (2012). Small Farmers and Big Retail: Trade-offs of Supplying Supermarkets in Nicaragua. World Development, 40(2), 342-354.

Minten, B., Randrianarison, L., \& Swinnen, J. F. M. (2009). Global Retail Chains and Poor Farmers: Evidence from Madagascar. World Development, 37(11), 1728-1741.

Mishili, F. J., Fulton, J., Shehu, M., Kushwaha, S., Marfo, K., Jamal, M., ... LowenbergDeBoer, J. (2009). Consumer preferences for quality characteristics along the cowpea value chain in Nigeria, Ghana, and Mali. Agribusiness, 25(1), 16-35.

Mithofer, D. (2011). 3 Framework for Economic Impact Assessment of Production Standards and Empirical Evidence. Vegetable Production and Marketing in Africa: Socio-Economic Research, 25.

Miyata, S., Minot, N., \& Hu, D. (2009). Impact of Contract Farming on Income: Linking Small Farmers, Packers, and Supermarkets in China. World Development, 37(11), 1781-1790.

Moser, C., Barrett, C., \& Minten, B. (2009). Spatial integration at multiple scales: rice markets 
in Madagascar. Agricultural Economics, 40(3), 281-294.

Murray, D. (1991). Export agriculture, ecological disruption, and social inequity: Some effect of pesticides in Southern Honduras. Agriculture and Human Values, 8(4), 19-29.

Nagaraj, N., Chandrakanth, M. G., Chengappa, P. G., Roopa, H. S., \& Chandakavate, P. M. (2008). Contract farming and its implications for input-supply, linkages between markets and farmers in Karnataka. Agricultural Economics Research Review, 21, 307-316.

Narayanan, S., \& Gulati, A. (2002). Globalization and the smallholders: a review of issues, approaches, and implications (Markets and Structural Studies Division, Discussion Paper No. 50). Washington, DC.: IFPRI and World Bank.

Narrod, C., Roy, D., Okello, J., Avendaño, B., Rich, K., \& Thorat, A. (2009). Public-private partnerships and collective action in high value fruit and vegetable supply chains. Food Policy, 34(1), 8-15.

Naschold, F. (2012). “The Poor Stay Poor”: Household Asset Poverty Traps in Rural Semi-Arid India. World Development, 40(10), 2033-2043.

Neven, D., Odera, M. M., Reardon, T., \& Wang, H. (2009). Kenyan Supermarkets, Emerging Middle-Class Horticultural Farmers, and Employment Impacts on the Rural Poor.

Agrifood Industry Transformation and Small Farmers in Developing Countries, 37(11), 1802-1811.

Omamo, S. W. (1998a). Farm-to-market transaction costs and specialisation in small-scale agriculture: Explorations with a non-separable household model. Journal of Development Studies, 35(2), 152-163.

Omamo, S. W. (1998b). Transport Costs and Smallholder Cropping Choices: An Application to Siaya District, Kenya. American Journal of Agricultural Economics, 80(1), 116-123.

Palma Munguia, J. S. (2014, April). Informacion Proyecto.

Pingali, P. (2007). Agricultural growth and economic development: a view through the globalization lens. Agricultural Economics, 37, 1-12.

Pingali, P., \& Khwaja, Y. (2005). Commercializing small farms: Reducing transaction costs. The Future of Small Farms, 61.

Ramsey, J. B. (1969). Tests for specification errors in classical linear least-squares regression analysis. Journal of the Royal Statistical Society. Series B (Methodological), 350-371.

Rao, E. J. O., \& Qaim, M. (2011). Supermarkets, farm household income, and poverty: insights from Kenya. World Development, 39(5), 784-796.

Rapsomanikis, G., Hallam, D., \& Conforti, P. (2006). Market integration and price transmission in selected food and cash crop markets of developing countries: review and applications. In Agricultural Commodity Markets and Trade (Alexander S. and Hallam, D.) (pp. 187217).

Ravallion, M. (1986). Testing Market Integration. American Journal of Agricultural Economics, 68(1), 102-109.

Reardon, T., Barrett, C. B., Berdegué, J. A., \& Swinnen, J. F. M. (2009). Agrifood Industry

Transformation and Small Farmers in Developing Countries. World Development, 37(11), 1717-1727.

Reardon, T., Berdegué, J. A., \& Farrington, J. (2002). Supermarkets and farming in Latin America: pointing directions for elsewhere?. Overseas Development Institute.

Reardon, T., \& Timmer, C. P. (2007). Transformation of Markets for Agricultural Output in Developing Countries Since 1950: How Has Thinking Changed? In R. Evenson and P. 
Pingali (Ed.), Handbook of Agricultural Economics (Vol. Volume 3, pp. 2807-2855).

Elsevier.

Reardon, T., Timmer, C. P., Barrett, C. B., \& Berdegue, J. (2003). The rise of supermarkets in Africa, Asia, and Latin America. American Journal of Agricultural Economics, 85(5), 1140-1146.

Renkow, M., Hallstrom, D. G., \& Karanja, D. D. (2004). Rural infrastructure, transactions costs and market participation in Kenya. Journal of Development Economics, 73(1), 349-367.

Ricardo, D. (1891). Principles of political economy and taxation. G. Bell and sons.

Rodríguez Lizano, V. (2014). Price transmission in the Costa Rican black bean market. University of Göttingen, Göttingen, Germany.

Romer, P. (1994). New goods, old theory, and the welfare costs of trade restrictions. Journal of Development Economics, 43(1), 5-38.

Rosen, S. (1974). Hedonic prices and implicit markets: product differentiation in pure competition. The Journal of Political Economy, 34-55.

Royston, P. (1992). Comment on sg3. 4 and an Improved D'Agostino Test. Stata Technical Bulletin, 1(3).

Schipmann, C., \& Qaim, M. (2010). Spillovers from modern supply chains to traditional markets: product innovation and adoption by smallholders. Agricultural Economics, 41(34), 361-371.

Schipmann, C., \& Qaim, M. (2011). Modern Food Retailers and Traditional Markets in Developing Countries: Comparing Quality, Prices, and Competition Strategies in Thailand. Applied Economic Perspectives and Policy, 33(3), 345-362.

Shepherd, A. (2007). Approaches to linking producers to markets : a review of experiences to date. Rome: Food and Agriculture Organization of the United Nations.

Siqueira, K. B., Kilmer, R. L., \& Campos, A. C. (2010). The dynamics of farm milk price formation in Brazil. Revista de Economia E Sociologia Rural, 48(1), 41-61.

Smith, R. J., \& Blundell, R. W. (1986). An Exogeneity Test for a Simultaneous Equation Tobit Model with an Application to Labor Supply. Econometrica, 54(3), 679-685.

Stoian, D., Donovan, J., Fisk, J., \& Muldoon, M. F. (2012). Value chain development for rural poverty reduction: A reality check and a warning. Enterprise Development and Microfinance, 23(1), 54-60.

Straub, S. (2008). Infrastructure and Growth in Developing Countries : Recent Advances and Research Challenges. World Bank Policy Research Working Paper, 4460.

Straub, S. (2011). Infrastructure and Development: A Critical Appraisal of the Macro-level Literature. The Journal of Development Studies, 47(5), 683-708.

Subervie, J., \& Vagneron, I. (2013). A Drop of Water in the Indian Ocean? The Impact of GlobalGap Certification on Lychee Farmers in Madagascar. World Development, 50(0), 57-73.

Swinnen, J. F. M. (2007). Global supply chains, standards and the poor how the globalization of food systems and standards affects rural development and poverty. Wallingford, UK; Cambridge, MA: CABI.

Teuber, R., \& Herrmann, R. (2012). Towards a differentiated modeling of origin effects in hedonic analysis: An application to auction prices of specialty coffee. Food Policy, 37(6), 732-740.

The Economist. (2011, March). Restrictions on bean exports spark criticism. Retrieved 
December 9, 2014, from

http://country.eiu.com/article.aspx?articleid=1837888768\&Country=Nicaragua\&topic=E conomy\&subtopic_5

Timmer, C. P. (1988). The agricultural transformation. Handbook of Development Economics, 1(Part II), 276-331.

Timmer, C. P. (1997). Farmers and Markets: The Political Economy of New Paradigms. American Journal of Agricultural Economics, 79(2), 621-627.

Timmer, C. P. (2010). Reflections on food crises past. Food Policy, 35(1), 1-11.

Torero, M. (2011). A Framework for Linking Small Farmers to Markets. Presented at the Conference on New Directions for Smallholder Agriculture, Rome: IFAD.

USTR. (n.d.). CAFTA-DR (Dominican Republic-Central America FTA) | Office of the United States Trade Representative. Retrieved October 23, 2014, from http://www.ustr.gov/tradeagreements/free-trade-agreements/cafta-dr-dominican-republic-central-america-fta

Vieira, L. M. (2008). The applicability of transaction costs economics to vertical integration decision: evidences from a Brazilian beef processor. Rural and Agro-Industrial Organizations, 10(3), 317-327.

Von Braun, J., Sheeran, J., \& Ngongi, N. (2008). Responding to the Global Food Crisis-Three perspectives: IFPRI 2007-2008 Annual Report Essay. Intl Food Policy Res Inst.

Whitfield, L. (2012). Developing technological capabilities in agro-industry: Ghana's experience with fresh pineapple exports. Journal of Development Studies, 48(3), 308321.

Wooldridge, J. M. (2010). Econometric analysis of cross section and panel data. MIT press.

World Bank. (2007). World development report 2008 agriculture and development. Washington, D.C.; London: World Bank.

World Bank. (2012). Unlocking Central America's Export Potential (No. 75070 v2). World Bank.

Zhang, L., Rozelle, S., Liu, C., Olivia, S., De Brauw, A., \& Li, Q. (2006). Feminization of Agriculture in China: Debunking the Myth and Measuring the Consequence of Women Participation in Agriculture. Washington, D.C: World Bank. 